\title{
THE REEF-CORAL FAUNA OF CARRIZO CREEK, IMPERIAL COUNTY, CALIFORNIA, AND ITS SIGNIFICANCE.
}

\author{
By Thomas Wayland Vaughan.
}

\section{INTRODUCTION.}

Knowledge of the existence of the unusually interesting coral fauna here discussed dates from the exploration of Coyote Mountain (also known as Carrizo Mountain) by H. W. Fairbanks in the early nineties. ${ }^{1}$ Dr. Fairbanks sent the specimens of corals he collected to Prof. John C. Merriam, at the University of California, who in turn sent them to me. There were in the collection representatives of two species and one variety, which I described under the names Favia merriami, ${ }^{2}$ Stephanocœnia fairbanksi, ${ }^{3}$ and Stephanocœnia fairbanksi var. columnaris. ${ }^{4}$ As the geologic horizon was not even approximately known at that time, I gave it as "doubtfully Cretaceous" in the paper cited.

Late in 1903 Dr. Stephen Bowers sent to me for examination a small collection of fossils obtained by him in the Carrizo Creek area during June and July, 1901. ${ }^{5}$ This collection contained corals whose affinities are undoubtedly with Pliocene, Pleistocene, and Recent species of the western Atlantic region, and not with any known living Indo-Pacific fauna. The following statement was made in a paper based on this collection. ${ }^{6}$

In the collection that has so far been made from the California fossil reef five genera are represented, all of which occur in the fossil and recent faunas of the Antilles and not one of which is at present known to occur on the Pacific coast. The age of the beds in which these fossils

1 California State Min. Bur. Eleventh Ann. Rept., pp. 88-90, 1893.

2 Vaughan, T. W., The Eocene and lower Oligocene coral faunas of the United States: U. S. Geol. Survey Mon. 39, p. 142, pl. 15, figs. 5, 5a, 5b, 5c, 1900.

8 Idem, p. 151, pl. 17, figs. 11, 11a.

4 Idem, pp. 151, 152, pl. 17, figs. 10, 10a.

5 A brief report on his field observations was made by Dr. Bowers in an article entitled "Reconnaissance of the Colorado Desert mining district," 19 pp., California State Min. Bur., 1901.

${ }^{6}$ Vaughan, T. W., A Californian Tertiary coral reef and its bearing on American recent coral faunas: Science, new ser., vol. 19, p. 503, Mar. 24, 1904. occur has been determined by Drs. Arnold and Dall to be lower Miocene. The following conclusions seem warranted: (1) There was water connection between the Atlantic and Pacific across Central America not much previous to the upper Oligocene or lower Miocene-that is, during the upper Eocene or lower Oligocene. This conclusion is the same as that reached by Messrs. Hill and Dall, theirs, however, being based upon a study of the fossil mollusks. (2) During lower Miocene time the West Indian type of coral fauna extended westward into the Pacific, and it was subsequent to that time that the Pacific and Atlantic faunas have become so markedly differentiated.

As it will be made evident on subsequent pages that this fauna is much younger than lower Miocene, the inference as to the date of the interoceanic connection given in the foregoing quotation must be modified.

After receiving the specimens from Dr. Bowers and recognizing the need of more careful geologic studies in the Carrizo Creek area, I brought the matter to the attention of C. W. Hayes, then chief geologist of the Survey, and in January, 1904, arrangements were made for an expedition to the region, in charge of W. C. Mendenhall, who was accompanied by Dr. Bowers. Mr. Mendenhall conducted the physiographic and stratigraphic studies and Dr. Bowers made a large collection of fossils.

As it was my intention to publish promptly an account of the fossil corals, I furnished to Ralph Arnold, for publication in his paper entitled "The Tertiary and Quaternary pectens of California," " a list which contained three nomina nuda, but other duties prevented my completing a report until the summer of 1916 . The list furnished and published was based on the collection submitted by Dr. Bowers before he made the expedition with Mr. Mendenhall. It is given in the first column of the list on page 356. The second column gives the names applied in this paper. 
Fossil corals from Carrizo Creek, Cal.

Name in Prof. Paper 47, p. 22. Diploria bowersi Vaughan (MS.).

Favia merriami Vaughan.

Plesiastrea calif or n i ca Vaughan (MS.).

Siderastrea califor nica

Vaughan (MS.)

Stephanocœnia fairbanksi Vaughan.

Stephanocœnia fairbanksi var. columnaris Vaughan.
Revised name.

Mæandra bowersi Vaughan.

Dichocœnia merriami (Vaughan).

Solenastrea fair ban ks (Vaughan).

Siderastrea californica Vaughan.

Solenastrea fairbanksi (Vaughan).

Solenastrea fairbanksi var. columnaris (Vaughan) some of the photographs. The illustrations showing the geologic conditions under which the fossil corals occur are reproductions of photographs taken by Mr. Mendenhall, and I am making extensive quotations from his article entitled "Notes on the geology of Carrizo Mountain and vicinity, San Diego County, Cal." 1

\section{GEOGRAPHIC RELATIONS.}

The accompanying sketch map (fig. 43) is taken from the article by Mr. Mendenhall, who

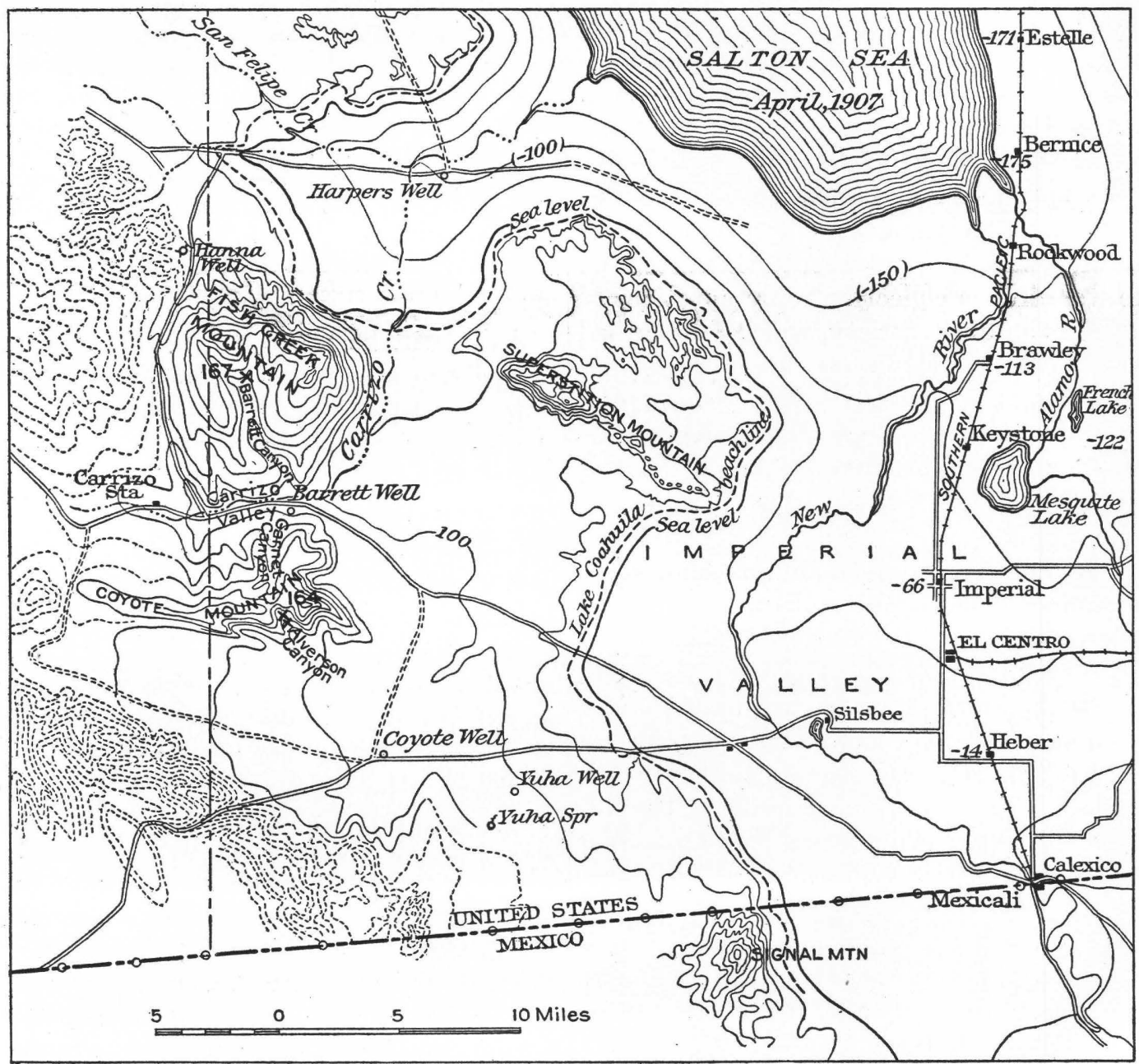

FIGURE 43.-Sketch map of Coyote Mountain, Cal., and vicinity, showing localities in Alverson and Barrett canyons where fossil corals were collected. (After Mendenhall.)

Messrs. Mendenhall and Bowers shipped to gives the following graphic description of the Washington over 400 specimens of corals, and it is on this large collection that the present paper is mostly based. All the photographs of corals herein illustrated were made by Mr. W. O. Hazard, except those for Plate XCIX, which were contributed by Dr. Charles Gravier, of general geographic relations:

Black and Carrizo mountains, known also as Fish Creek and Coyote mountains, are eastern outliers of the Peninsula Range that separates the depression occupied in part by the Gulf of California from the Pacific Ocean. They are Paris. Miss Frances Wieser has retouched in southeastern California near the western edge of the 
Colorado Desert and from 15 to 30 miles north of the international boundary. East of them the Colorado Desert, much of it below sea level, extends to the Colorado River, while to the west low ridges extend to the base of the main Peninsula Range.

The two masses are separated by the valley of Carrizo Creek. This stream rises in Mexico, flows north for several miles, through a high valley in the Peninsular Mountains, then descends to the desert level through a precipitous canyon. Nearly all of that part of its channel that lies within the desert is dry except during rare flood periods, when its waters join those of San Felipe Creek, north of Black Mountain, and eventually reach the Salton depression. At Carrizo Station, one of the relief stations of the old Butterfield stage line, a series of springs rise, and for 1 to 2 miles below this point flowing water is found in the creek bed except during the hottest period of summer.

The desert floor at the eastern base of the peaks is generally from 100 to 200 feet above sea level, but on the north side of Black Mountain the sea-level contour and the old beach of Lake Cahuilla, 40 feet above sea level, swing in against the mountain base. In the past the region has been rather difficult of access because of its remoteness from settlements and its aridity. With the colonization of the Imperial Valley since 1900 and the building of the branch railroad from Old Beach to Calexico, however, this condition has been greatly modified. Now Carrizo Station or Coyote Well may be reached by one day's drive from Imperial or El Centro, and supplies are readily secured at many points in the valley. The

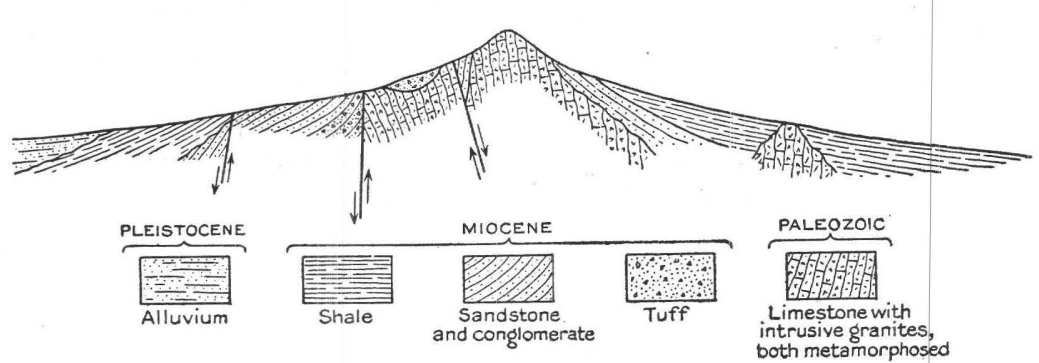

FIGURE 44.-Diagrammatic section across Coyote Mountain, Cal., by way of Alverson and Garnet old roads from the desert to San Diego, the one running north of Carrizo Mountain by way of Julian and the other south of the mountain by way of Jacumba and Campo, are still much used for direct communication between the Imperial Valley and the coast, although the Campo road below Mountain Springs is rough and after storms is nearly impassable.

\section{GEOLOGIC RELATIONS.}

The following is Mendenhall's account of the broader geologic relations within the area:

Carrizo [Coyote] and Black [Fish Creek] mountains are islands of granitic and metamorphic rocks which rise through encircling terranes of later sediments and volcanics. These later beds are Miocene and younger, and the unconformity which exists between them and the older rocks upon which they lie is profound. The time interval represented by this unconformity is not known, because the age of the altered rocks below it is a matter of uncertainty. Fairbanks ${ }^{1}$ expresses the opinion that they are Carboniferous or older, the opinion being based presumably upon their general resemblance to upper Paleozoic socks in other parts of California and upon the aspect of rome shells found in a float piece of siliceous limestone. Accepting this determination as the best possible in the state of our knowledge, we must conclude that the Triassic, Jurassic, and Cretaceous systems are without depositional

${ }^{1}$ Fairbanks, H. W., California State Mineralogist Eleventh Rept., pp. $88-90,1893$. canyons. (After Mendenhall.)

representatives in this region. Either the Carrizo and Black Mountain areas were land masses subject to erosion during this interval or the evidence of such periods of deposition as intervened was later removed by erosional processes.

The Miocene seems to have been inaugurated by volcanic activity. On the southern slopes of both Carrizo and Black Mountains are bedded tuffs, volcanic conglomerates, and less extensive masses of dark lavas of andesitic aspect. On Black Mountain there are distinct sandstones interbedded with these and directly upon them lie the Miocene coral reefs. In Alverson Canyon, which drains south from Carrizo Mountain, red vesicular lavas are succeeded by green and lavender sandstones and conglomerates, whose constituent materials are volcanic, and these in turn grade into conglomerates with a diminishing proportion of volcanic pebbles. Above them are quartz conglomerates, tawny sandstones, and finally soft greenish-yellow clay shales.

An unconformity which is not especially conspicuous exists in the Miocene between the sandy shell-bearing beds, 100 feet or less in thickness, which immediately overlie the volcanics or the metamorphics, and the great mass of shales, greenish or yellowish at base, pink or pale red in general color tone toward the top, which form the badland area that is especially well developed between Black and Carrizo mountains. Finally, across the planed edges of these shale beds, a sheet of river cobbles, well rounded, has been distributed unconformably throughout the Carrizo Valley. They are probably Pleistocene but are earlier than the silts, sands, and gravels, which represent the offshore and beach deposits of the lake which until recently has occupied the Colorado Desert. The latest erosion has left these old stream deposits stranded upon the remnants of the earlier valley floor at heights of from 100 to 200 feet above the present bed of Carrizo Creek.

Figures 44 and 45 are copied from Mendenhall's paper, and the accompanying sketch geologic map (fig. 46) is taken from a paper by Kew. ${ }^{2}$ It should be noted that the name Carrizo sandstone, shown on this map, has been in use since 1889 for a geologic formation of Eocene age exposed along and near the Rio Grande in Texas, and since 1891 for an Algonkian(?) formation in western Texas. The name therefore can not be properly applied to these California deposits.

${ }^{2}$ Kew, W.S. W., Tertiary echinoids of the Carrizo Creek region, in the Colorado Desert: California Univ. Dept. Geology Bull,, vol. 8, p. 41, 1915. 


\section{GEOLOGIC HISTORY}

The following outline of the geologic history of the area is also taken from the article by Mendenhall:

The story of the development of this part of the country can not be read with any approach to accuracy as yet for any period beyond the Miocene. The rocks which represent earlier time are marmarized limestones, schists, and gneisses, as to whose age there is much doubt. The slight existing evidence points toward the Carboniferous as the period during which the limestones were deposited here. Whatever their age, their condition now indicates that their history previous to the Miocene was one involving deep burial and intense earth strain. They were upturned, intruded, and crystallized, uplifted and eroded

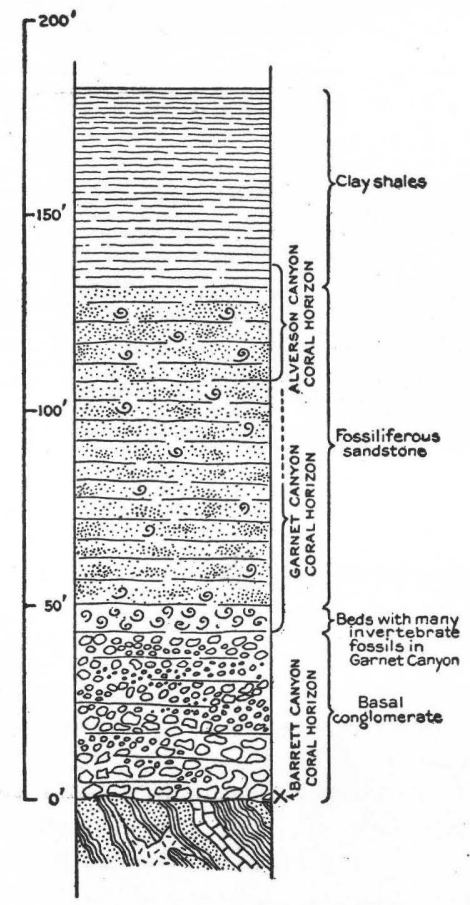

FIGURE 45.-Columnar section of rocks exposed in Garnet Canyon, Cal. (After Mendenhall.)

into a mountainous topography, and at the beginning of the late Miocene formed islands in a sea teeming with life. Volcanic forces were active at this time, and the flanks of the old land mass are partly buried under the effusive material which issued then, and the muds and the littoral whose fragments were supplied from volcanic sources are conspicuous at many points. But as the period advanced volcanism ceased, and the present Carrizo and Black mountains were surrounded and perhaps for a part of the time were submerged beneath a clear sea in which the myriad forms of the life of the period swarmed. Still later in the Miocene the character of the sea changed. Instead of clear, salt water, some realignment of forces caused great quantities of muddy, brackish water to spread about the old islands. Oysters of many forms, some of them of great size, some very tiny indeed, flourished. The heavy silts of these muddy waters accumulated to great depths as the land subsided. Finally the waters withdrew, presumably because of reelevation, and the region was land again as it had been before, and the shells of many of the creatures which had lived in the clear and then in the muddy waters were preserved in the accumulated sediments. As the sea withdrew the destructive forces of weathering and the erosive forces of wind and running water became active. The clays which had accumulated were now dry and were cut away again by these forces. The process was not long continued and the plain was not completed, those clay areas which were capped by protecting sandstones remaining as monadnocks above the wide valley floor. This valley, occupied by an earlier vigorous ancestor of Carrizo Creek, was strewn with rounded river cobbles brought from the higher mountains to the west. South and east of Carrizo Mountain large areas seem to have been reduced at this period well toward the condition of a peneplain. This plain lies perhaps 200 feet above the later Pleistocene lake level, with which it seems to have no connection. It is regarded as an earlier independent feature, perhaps Pliocene in age.

After the formation of this partially planed surface over the soft rocks of Carrizo Valley some change, either in the relations of land and sea or of climatic conditions, enabled the streams to dissect it again. The result of this dissection, which may well have been contemporaneous with the last occupancy of the Colorado Desert by the Gulf of California, is seen in the Carrizo Creek badlands of to-day.

The last important element in the development of the geography of this part of the desert was the formation and the disappearance of the desert lake. So late is it that the calcium carbonate incrustations which it left on its western shore show but little effect of erosive or solvent action since the waters left them, and the sandy beach, molded by the waves of the lake upon the alluvial fans which formed a large part of its shores, is still well enough preserved to be readily traced. Only the most modern gullies have cut it away. At one point a low sea cliff notched by the waves in steep alluvial-fan material still stands, as perfectly preserved as though the waters had just withdrawn.

\section{THE CORALLIFEROUS BEDS.}

The fossil corals occur in that part of the columnar geologic section designated "Miocene conglomerates," by Mendenhall. The following is his description of these beds:

In the lower part of Alverson Canyon a heavy conglomerate bed 120 to 130 feet thick overlies a series of tuffaceous strata. This bed is composed of coarse naterial at the base but becomes finer at the top. It is only moderately hard, and along its upper margin is an abundantly fossiliferous horizon. Splendid coral heads are embedded in these sandstones, and more delicate forms are found at the base of the superjacent sandy shales. These corals with the molluscan remains that accompany them, all of which await detailed examination and determination, prove the age of the inclosing rocks to be upper Miocene. [See Pl. XCII.]

On the north slope of Carrizo [Coyote] Mountain, about the head of the easternmost arroyos which are tributary to Garnet Canyon, another series of fragments of a well- 


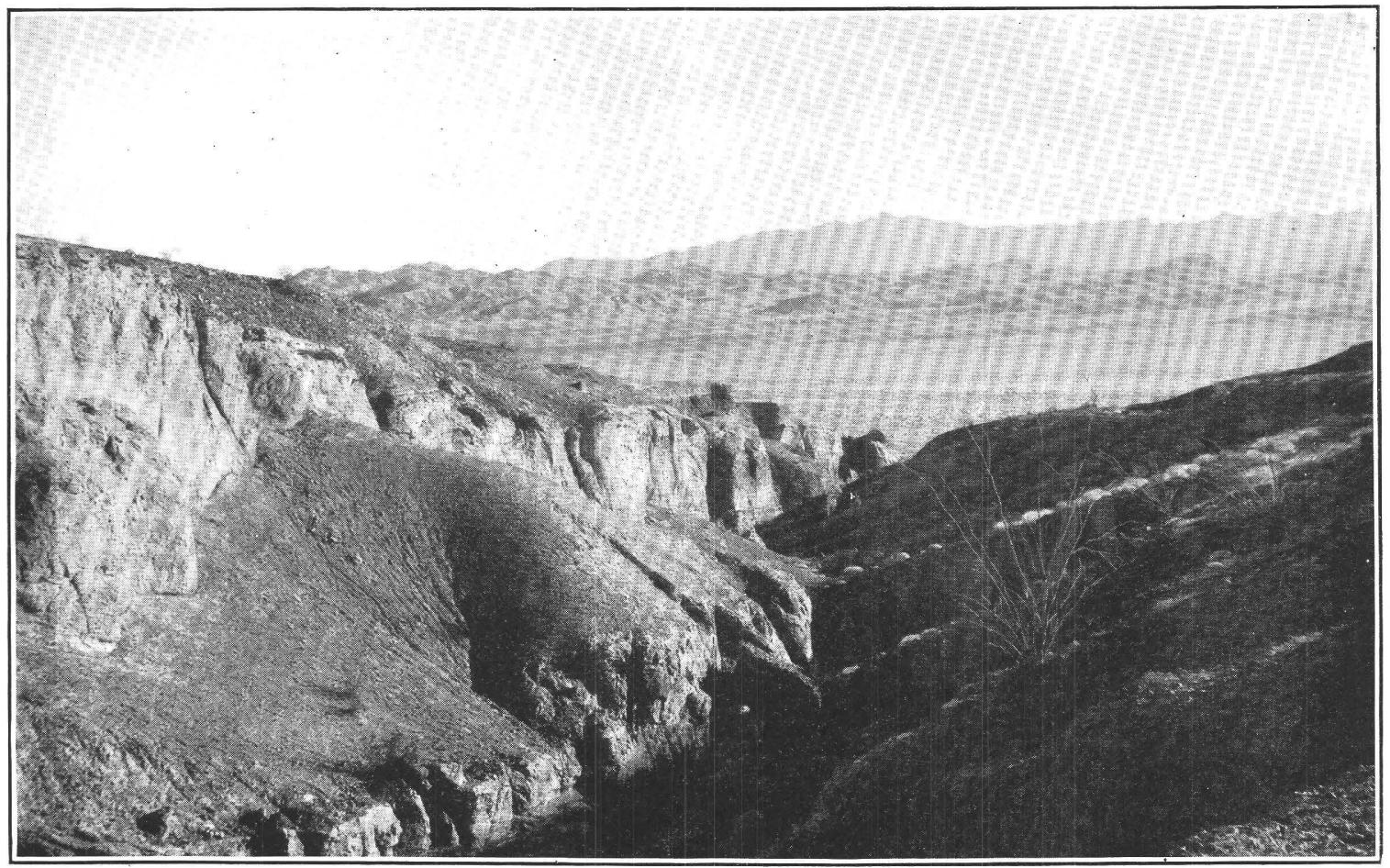

A. VIEW LOOKING DOWN ALVERSON CANYON FROM A POINT NEAR ITS HEAD.

Coyote Wells Valley in the middle distance. Fossil corals and mollusks are found all along the canyon in sandstones overlying shales.

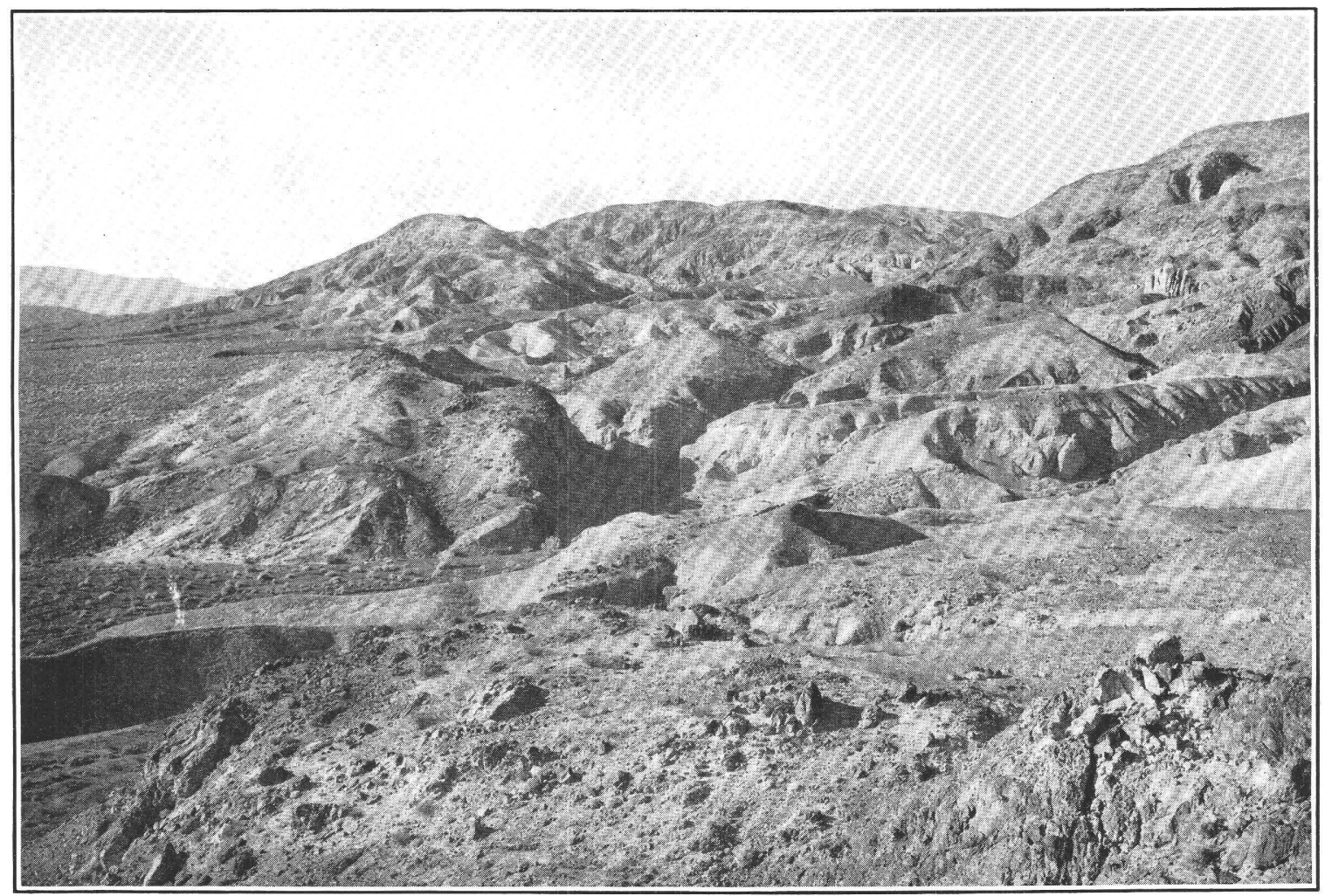

B. VIEW LOOKING N. $35^{\circ}$ W. ACROSS THE MOUTH OF ALVERSON CANYON, FROM COYOTE

The fossiliferous Pliocene beds through which the shallow canyon is cut are shown in the middle ground.

Views of Alverson Canyon, imperial County, Cal. Photographs and explanations by W. C. Mendenhall. 
developed basal conglomerate are encountered. They $/$ spread out over the sandstones were deposited directly extend well up the slopes of the older metamorphic rocks which form the axis of the mountain and dip away from it toward the north or northeast at the rate of $20^{\circ}$ or $30^{\circ}$. Being more resistant to weathering agencies than the soft overlying shales, these have been stripped from the sandupon the metamorphic rocks that form the core of the mountain and must at one time have formed the bottom and shores of the Miocene sea. The simplest interpretation of this relation is to suppose that before that change of conditions was complete which substituted muddy

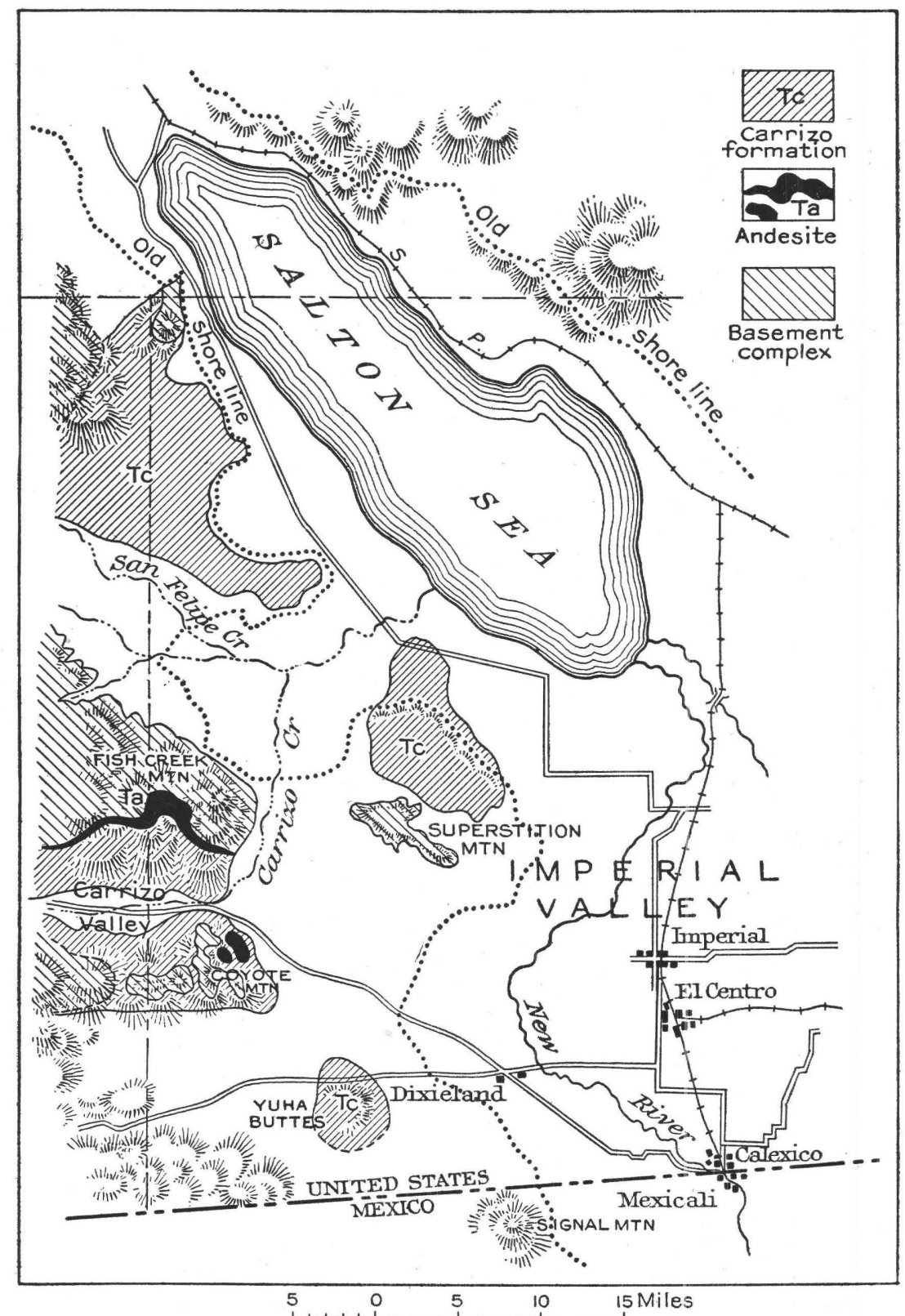

FIGURE 46.-Geologic sketch map of the southwestern part of the Colorado Desert, Cal., north of the Mexican boundary line, showing position of the geologic formations. Areas in the valleys represented without formational symbol are occupied by Pleistocene lake beds and alluvium. (After Kew.)

stones at many points so that the old Miocene beach, its sands indurated and its teeming life preserved only in fossil form but yet exhibiting much the aspect and much the same relations which existed at the time of its deposition, is revealed for the modern student's inspection. These basal sands are not always found where their horizon is exposed. In many places the fine clays that were brackish water with oyster colonies for clear sea water and marine life, the sands of the earlier beach had been swept away, so that there is unconformity, without discordance, or at least without marked discordance in dips, and without a great time interval between the deposition of the sands and the deposition of the muds. The other hypothesis, namely, that these beach sands and the muds 
were deposited contemporaneously, because of differing local conditions, is made difficult to apply because the two physically different terranes overlie the basement rocks at very closely adjacent points, with no obvious explanation as to why such different conditions should have prevailed so near together.

The heavy sandstones occur at a number of places along the north slope of Carrizo Mountain, east of the head of Garnet Canyon. Many arroyos are incised in them, the stream channel in some cases being a mere notch but a few feet wide and 100 or more deep. Fossils, however, have not been reported in numbers except at the head of Garnet Canyon.

At the head of Barrett Canyon, which drains south from Black Mountain, the same general relations prevail that have been described in the area a dozen miles to the south; on the slopes of Carrizo Mountain. But the fragments of the basal beds of the Miocene are even more widely scattered, and the sandstones and conglomerates are not so fully developed.

About $4 \frac{1}{2}$ miles above the mouth and one-half mile above the forks of the arroyo the basal beds of the Miocene flank the older rocks and extend across the valley from the west fork to the east fork. Dips here are $20^{\circ}-40^{\circ} \mathrm{S}$. - that is, away from the mountain. The beds are not so thick as on Carrizo Mountain but are succeeded, as is the case there, by soft yellow shales.

About a mile above this point, in a little cove at the head of a small western tributary of Barrett Creek, other outcrops of basal sandstone and conglomerate, not more than 10 feet thick, occur with the underlying igneous rocks all about them. Near this outcrop is a fossil coral reef lying upon the lavas and isolated from all the other sedimentaries. A half mile farther north a sheet of sandstone, folded into a basin and thus somewhat protected from erosion, still exists. Doubtless many other similar fragmental exposures would be revealed by more extended search. [See Pl. XCIII.]

The collections of fossil corals were obtained from localities numbered 164 and 167, respectively, by Messrs. Mendenhall and Bowers. The positions of these localities are platted on the map (fig. 43, p. 356). Mendenhall describes them as follows:

Nos. 164 and 166 are from Alverson Canyon and the head of Garnet Canyon on the south and north slopes, respectively, of Carrizo [Coyote] Mountain. The horizons are identical, being in each case the sandstones which form the upper part of the arenaceous series at the base of the Miocene. These are the most conspicuous fossil localities in the region. The shells or their casts have weathered out and strew the slopes in great profusion. Corals, echinoids, Ostrea, pectens, Strombus, and Malea are everywhere. The matrix, however, is coarse and only large and robust types are well preserved. The locality has been noted by prospectors generally because the occurrences are so conspicuous. [Views shown on Pl. XCII.]

No. 167. This collection consists of corals almost entirely. The fossil reef is near the head of Barrett Canyon and lies directly upon the igneous rocks which served as a base- ment for Miocene sedimentation at this point. Whatever later beds may have originally covered it have been stripped away, so that the old reef is now isolated. [View shown on Pl. XCIII.] There can be little doubt, however, that its position is at the base of the Miocene series and substantially equivalent to that of Nos. 164 and 166.

No. 164 of Mendenhall and Bowers is entered in the United States Geological Survey register of localities at which Cenozoic invertebrates have been collected as No. 3923; and No. 167 is entered there as No. 7616 .

The observations recorded in preceding paragraphs show that the reef corals grew up unconformably on a basement during a period of submergence that followed a period when the basement stood above sea level. These relations of vigorous coral growth to change of sea level have been found to prevail in so many areas where reef corals thrive that they appear to be general. ${ }^{1}$ The deposits in which the corals are embedded are largely arenaceous, and the reefs ultimately were probably killed by burial beneath sediment, as suggested by Mendenhall. At the time the reefs flourished there was, of course, shallow water in the area where their remains are now found, and the temperature probably averaged about $21^{\circ} \mathrm{C}$. $\left(70^{\circ} \mathrm{F}\right.$.) during the coldest months of the year. ${ }^{2}$

\section{SIGNIFICANCE OF THE CORAL FAUNA.}

\section{GENERIC AFFINITIES OF THE FAUNA OF CARRIZO CREEK.}

The discussion of this fauna may be best introduced by placing in parallel columns the names of the genera represented on Carrizo Creek, those of the shoal-water corals known to occur along the west coast of Central America from the Gulf of California to the Bay of Panama, and those of the genera found living in shoal water in the Floridian, Antillean, and eastern Central American region. The data for the column headed "Guaymas to Panama" are taken from a paper by Verrill. ${ }^{3}$

1 See Vaughan, T. W., Science, new ser., vol. 41, pp. 508, 509, Apr. 2 1915; Geol. Soc. America Bull., vol. 26, p. 58, 1915; Vaughan, T. W., and Shaw, E. W., Carnegie Inst. Washington Yearbook No. 14, pp. 237 $238,1916$.

${ }^{2}$ For recent discussions of the ecologic conditions necessary for the formation of coral reefs, see Vaughan, T. W., Physical conditions under which Paleozoic coral reefs were formed: Geol. Soc. America Bull., vol 22, pp. 238-252, 1911; Results of investigations of the ecology of the Floridian and Bahaman shoal-water corals: Nat. Acad. Sci. Proc., vol. 2 pp. 95-100, 1916; Temperature of the Florida coral-reef tract: Carnegie Inst. Washington Pub. 213, 1917.

3 Verrill, A. E., On the geographical distribution of the polyps of the west coast of America: Connecticut Acad. Arts and Sci. Trans., vol. 1, pp. $562,563,1870$ 


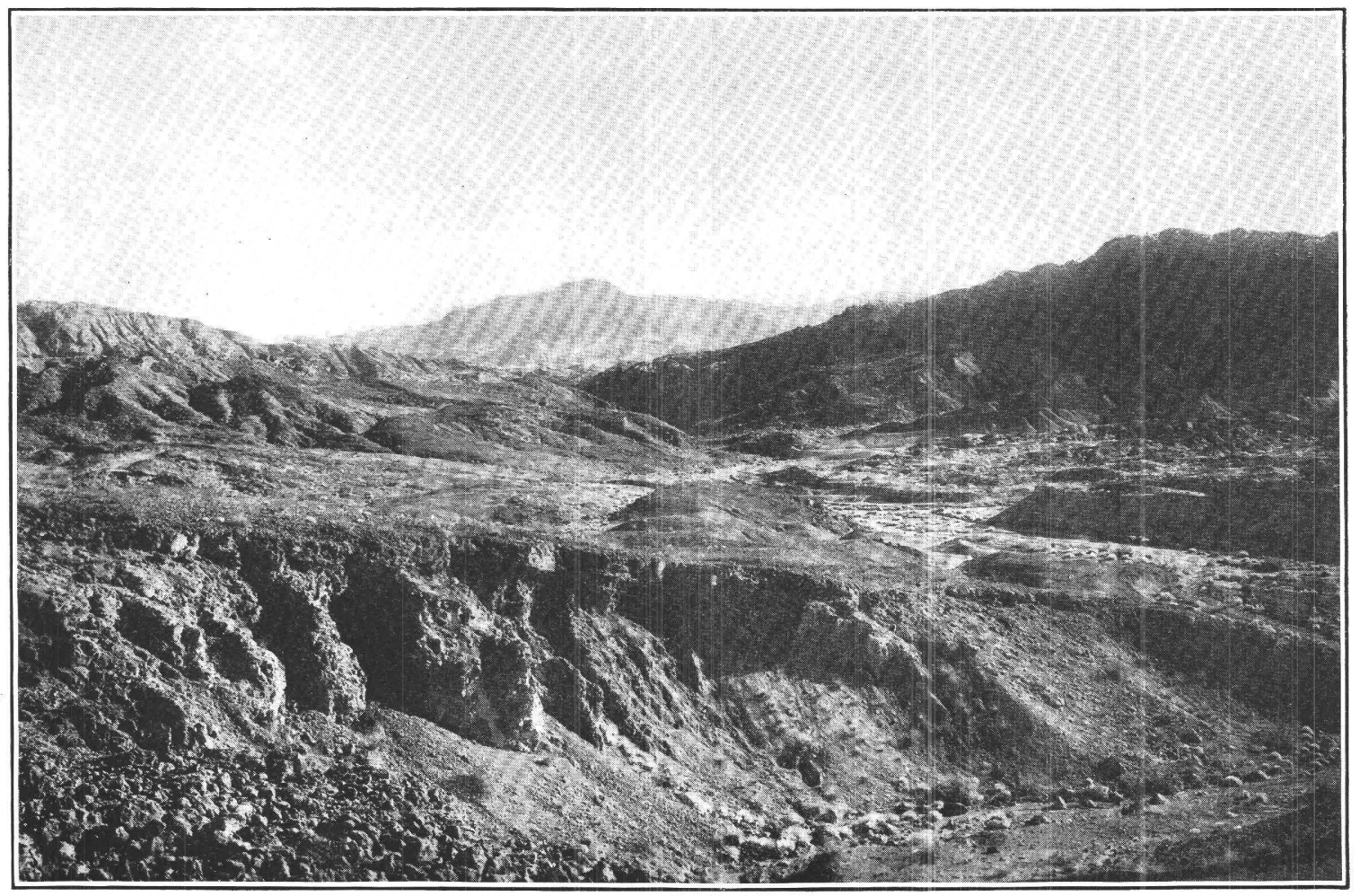

A. THE BARRETT CANYON FOSSIL CORAL REEF.

The reef is shown in the right middle ground. At this locality the corals rest directly upon the effusive rocks, which rise higher and form the surrounding hills.

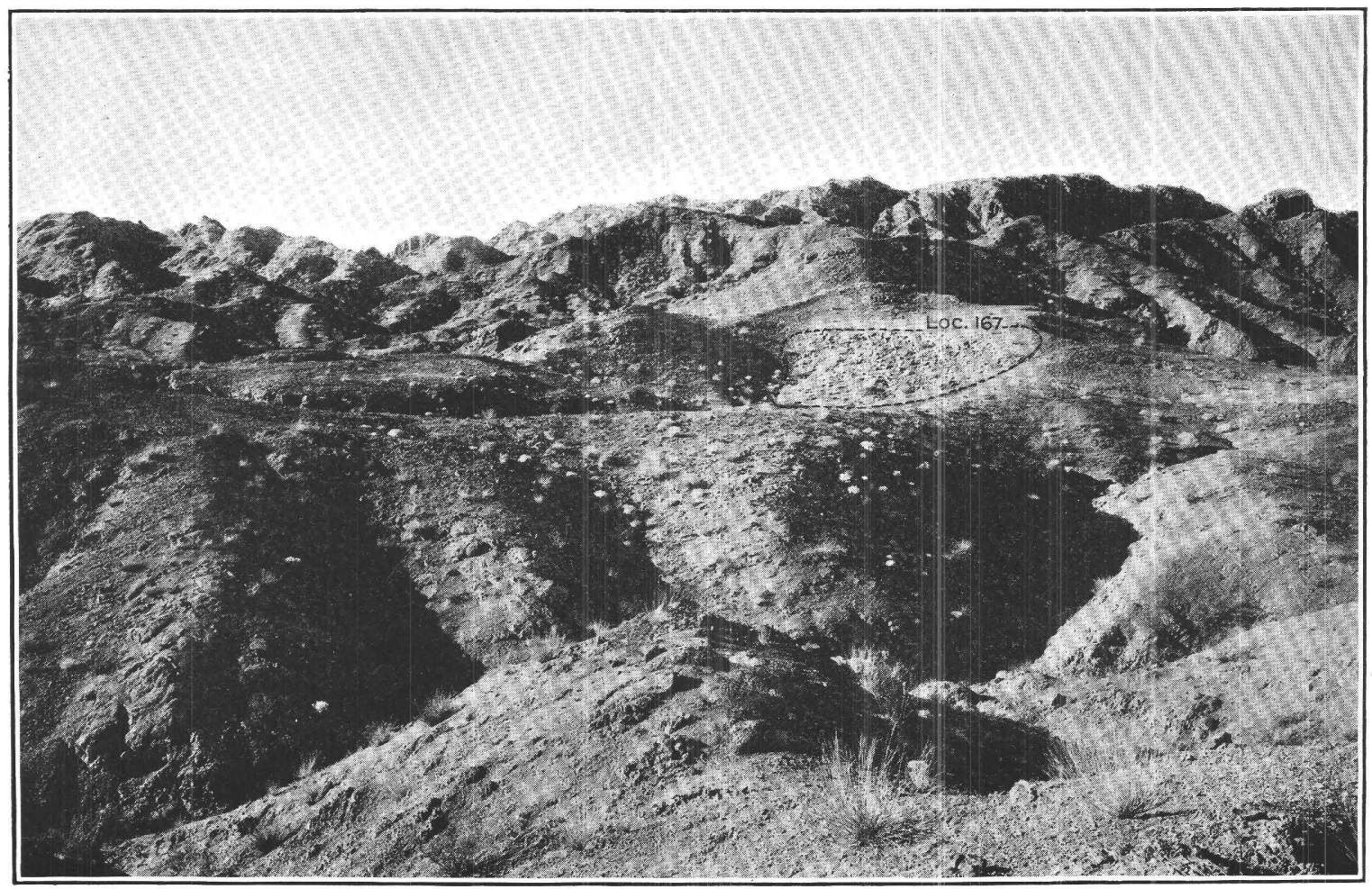

B. VIEW OF FOSSIL CORAL LOCALITY NEAR HEAD OF BARRETT CANYON.

The basal beds of the Pliocene sandstones overlie effusive rocks and dip to the right in the foreground of the view. The coral reef lies immediately upon the effusive rocks. Coyote Mountain in the background.

Views of Barrett Canyon, imperial County, Cal. Photographs and explanations by W. C. Mendenhall. 

Coral genera represented at Carrizo Creek, Cal., and on the west and east sides of Central America.

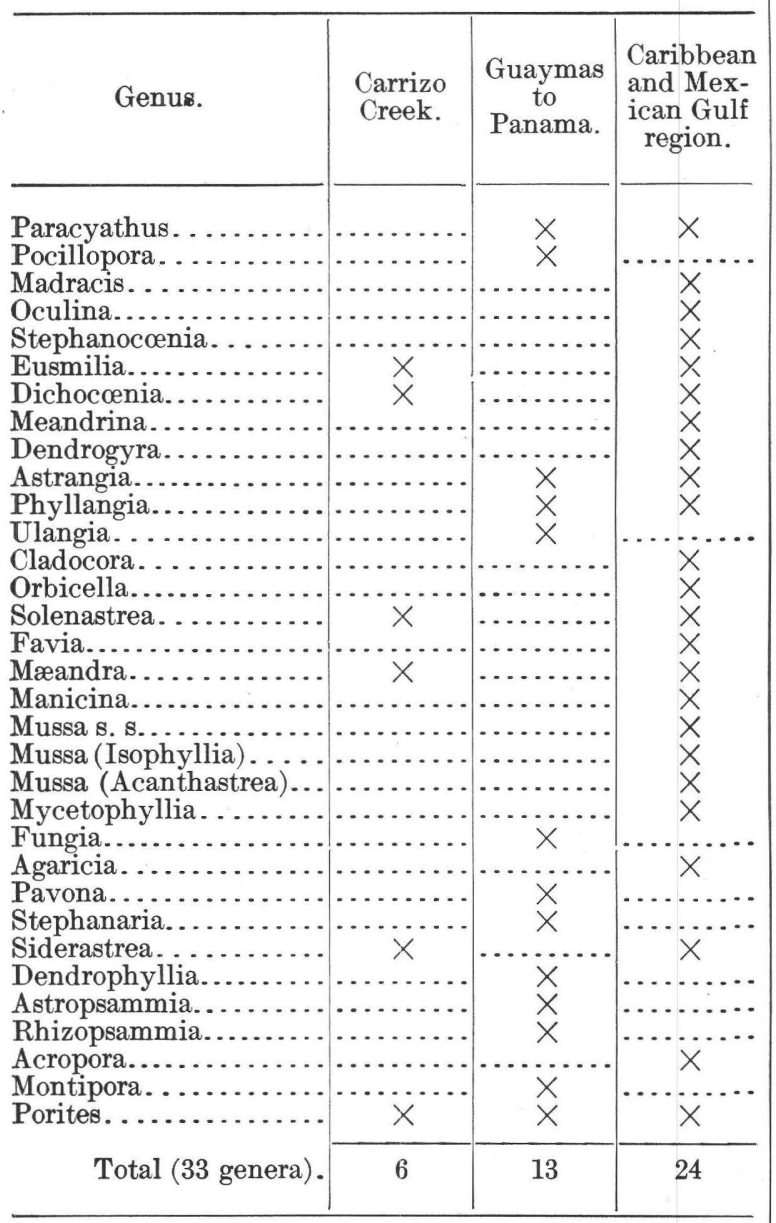

Six genera are included in the fauna of Carrizo Creek, only one of which (Porites) is at present known to occur on the west coast of America, though all six are found in the Gulf of Mexico and the Caribbean Sea. Of 13 shoal-water genera at present represented by species on the west coast of Central America, only 4 are represented on the east coast. One of the remaining 9 genera (Dendrophyllia) is found in the western Atlantic in water over 50 fathoms deep, but any similarity suggested by its presence may be offset by the fact that it is essentially worldwide in distribution. The genus Endopachys occurs in water 39 fathoms deep in the Gulf of California but is unknown in the West Indian and Floridian area. The table lists 24 West Indian genera, 4 of which also occur on the west side of Central America. The number 24 might be somewhat increased, as Verrill has described a species of Cyphastrea from the Bahamas, ${ }^{1}$ under the name Cyphastrea nodulosa, and I have in my possession an undescribed species of Oulophyllia from the Bahamas, sent to me by Miss A. M. Boynton, of Nassau. The Oulophyllia is strikingly similar to $O$. bonhourei Gravier, ${ }^{2}$ from French Somaliland. Both Cyphastrea and Oulophyllia are widely distributed in the Indo-Pacific, but they are not known to occur along the Pacific coast of Central America. Two West Indian shoalwater genera, Oculina and Cladocora, occur in deeper water off the Pacific coast.

The table shows the marked difference between the coral faunas on the two sides of Central America and indicates that the affinities of the fauna of Carrizo Creek are with the fauna of the Mexican Gulf and Caribbean area. Have the faunas on the two sides of Central America always been so distinct? An attempt is made to answer this question in the following discussion.

\section{GEOLOGIC HISTORY OF THE CORAL FAUNAS OF THE SOUTHEASTERN UNITED STATES AND THE WEST INDIES.}

\section{EOCENE AND LOWER OLIGOCENE FAUNAS.}

The data presented in the following table are largely taken from my monograph on the Eocene and lower Oligocene coral faunas of the United States, ${ }^{3}$ revised so as to represent the present stage of knowledge.

Geographic distribution of Recent genera of corals found also in the Eocene and lower Oligocene deposits of the southern United States.

\begin{tabular}{|c|c|}
\hline Genus. & Distribution. \\
\hline Flabellum....... & Almost universal. \\
\hline Sphenotrochus.. & $\begin{array}{l}\text { Mediterranean Sea and North Africa, } \\
\text { coast of Brazil, European coasts of } \\
\text { north Atlantic Ocean, South Aus- } \\
\text { tralian coast. }\end{array}$ \\
\hline Platytrochus.... & Australian seas (?) \\
\hline Turbinolia....... & Caribbean Sea, Indo-Pacific. \\
\hline Trochocyathus .. & $\begin{array}{l}\text { West Indies, South American seas, } \\
\text { Indo-Pacific. }\end{array}$ \\
\hline Paracyathus..... & $\begin{array}{l}\text { Mediterranean. Sea, Caribbean Sea, } \\
\text { north Atlantic Ocean, Indian Ocean, } \\
\text { Pacific Ocean, California (Pearl Is- } \\
\text { lands). }\end{array}$ \\
\hline Caryophyllia. & Littoral and deep sea, very general. \\
\hline
\end{tabular}

1 Verrill, A. E., Connecticut Acad. Arts and Sci. Trans., vol. 11, p. 107, pl. 31, figs. 2, 2a, 2b, 1902.

2 Gravier, Charles, Inst. océanogr. Annales, fasc. 3, p. 49, pl. 4, figs. 25, 26 ; pl. 5 , figs. $27,28,1911$

${ }^{3}$ U. S. Geol. Survey Mon. 39, pp. 33, 34, 1900. 
Geographic distribution of Recent genera of corals found also in the Eocene and lower Oligocene deposits of the southern United States-Continued.

\begin{tabular}{|c|c|}
\hline Genus. & Distribution. \\
\hline Oculina... & Florida, Caribbean Sea, Bermudas, \\
\hline Madrepora. & $\begin{array}{l}\text { Atlantic Ocean, Caribbean Sea, Medi- } \\
\text { terranean Sea, Indo-Pacific. }\end{array}$ \\
\hline yl & Red Sea, Indo-Pacific. \\
\hline & $\begin{array}{l}\text { Madeira, Florida, Caribbean Sea, Bra- } \\
\text { zil, Adriatic Sea, Indo-Pacific. }\end{array}$ \\
\hline Parasmilia. . & Caribbean Sea, Philippines. \\
\hline & $\begin{array}{l}\text { Florida, Central America, East Indies, } \\
\text { Panama Bay, east and west coasts of } \\
\text { North America, Strait of Magellan. }\end{array}$ \\
\hline icl & West Indies. \\
\hline & $\begin{array}{l}\text { Caribbean Sea, islands off west coast of } \\
\text { Africa, Indo-Pacific. }\end{array}$ \\
\hline Balanophyllia . . & $\begin{array}{l}\text { Caribbean Sea, Mediterranean Sea, } \\
\text { English Channel, St. Helena, Madeira, } \\
\text { California, Indo-Pacific. }\end{array}$ \\
\hline & Chinese seas. \\
\hline & West coast of America, Pacific. \\
\hline Dendrophyllia & $\begin{array}{l}\text { Caribbean Sea, Atlantic Ocean, Cape } \\
\text { Verde, Madeira, Mediterranean Sea, } \\
\text { Bay of Panama, California, Indo- } \\
\text { Pacific. }\end{array}$ \\
\hline roniop & Indo-Pacific. \\
\hline
\end{tabular}

The foregoing table shows that in their generic relations the Eocene and lower Oligocene corals of the southeastern United States are about equally divided between the Atlantic and the Indo-Pacific regions. There is a great resemblance between the species of Paracyathus, Balanophyllia, and Siderastrea now found in the West Indian region and the Eocene species of the same genera; but Platytrochus, Stylophora, Eupsammia, Endopachys, and Goniopora are not represented by known species from the Atlantic Ocean.

The difference between the Eocene faunas of the southern United States and the Eocene fauna of the West Indies is striking, as no known species is common to the two regions. The difference is probably due to two causes. One is climatic; the area in the United States lay so far north that except during early Midway and Vicksburg time it was not within the zone of truly tropical conditions. During Wilcox and Claiborne time and the earlier part of Jackson time the sea was warm-temperate but not actually tropical. For this reason reef corals did not abound in the southern United States during the Eocene epoch except in early Midway time. In the Jackson epoch there was a gradual recurrence of tropical conditions and during lower Oligocene time a well-developed coral reef, composed of species of Stylophora and Goniopora was formed at Salt Mountain, Ala. The other cause of faunal difference lies in the difference in stratigraphic history, as the known Eocene deposits of the West Indies include representatives of only the upper groups of the series. Because according to present knowledge the Antilles contain no Eocene deposits stratigraphically corresponding to the Midway, Wilcox, and probably Claiborne groups of the United States, they are supposed to have stood above sea level during the period of deposition of these groups.

There is a fairly rich Eocene coral fauna on the Island of St. Bartholomew and a scantier fauna is known from Jamaica. The principal literature on these faunas is cited below. ${ }^{1}$

The determination of the Eocene age of the St. Bartholomew coralliferous deposits is based on evidence of several kinds. A part of the evidence consists in my discovery in association with the coral fauna of a stellate orbitoidal foraminifer, closely resembling in general aspect a species I found in 1900 on Flint River near Bainbridge, Ga. Dr. Joseph A. Cushman has studied both the St. Bartholomew and the Flint River specimens and informs me that they belong to the genus Orthophragmina, which is considered to indicate positively an Eocene age.

In 1904 Prof. A. G. Hogböm, of the University of Upsala, sent to me for study the entire collection obtained on St. Bartholomew by Prof. Cleve, ${ }^{2}$ and during February, 1914, I spent eight days studying and collecting on the island. ${ }^{3}$ The following list of genera is based upon both these collections, and I have added the names of four genera represented in Jamaica (the names followed by " $J$ " in the table) but not known in St. Bartholomew.

1 Cleve, P. T., On the geology of the northeastern West India Islands: K. svenska Vet.-Akad. Handl., vol. 9, No. 12, p. 24, 1872.

Hill, R. T., The geology and physical geography of Jamaica: Harvard Coll. Mus. Comp. Zool. Bull., vol. 34, pp. 123-137, 1879.

Vaughan, T. W., Some Cretaceous and Eocene corals from Jamaica: Harvard Coll. Mus. Comp. Zool. Bull., vol. 34, pp. 227-256, pls. 36-41, 1899 Study of the stratigraphic geology $* * *$ of the smaller West Indian slands: Carnegie Inst. Washington Yearbook No. 13, pp. 358-360, 1915; [Present status of the geologic correlation of the Cretaceous and Tertiary formations of the Antilles]: Washington Acad. Sci. Jour., vol. 5, p. 489, 1915; Study of the stratigraphic geology $* * *$ of the smaller West Indian Islands: Carnegie Inst. Washington Yearbook No. 14, pp. 368-373, 1916.

2 P. M. Duncan's report on this collection was published in London Geol. Soc. Quart. Jour., vol. 29, pp. 548-565, pls. 19-22, 1873.

3 A minor grant from the Carnegie Institution of Washington enabled me to do geologic field work and make extensive collections in Antigua St. Bartholomew, and Anguilla during February and March, 1914. The discussion of the fossil corals of these islands herein presented is based largely on the collections made at that time. 
Corals in the upper Eocene of St. Bartholomew and Jamaica.

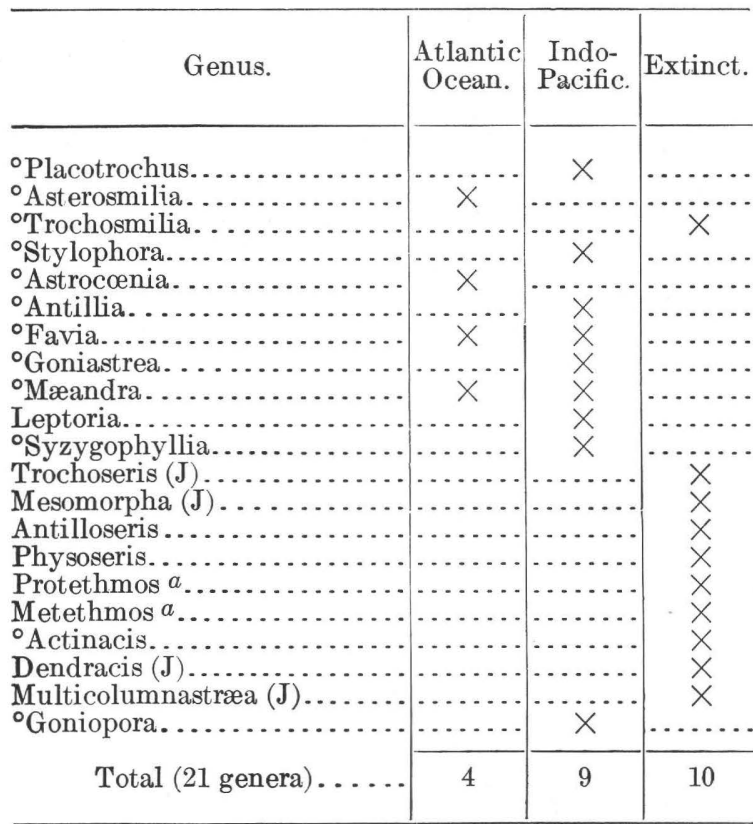

$a$ These two genera were described by Gregory (Palæontologia indica, 9 th ser., vol. 2, pt. 2, pp. 162-167, 1900) from specimens obtained in the Jurassic of Cutch, India, and appear to be represented in the Eocen of St. Bartholomew, but the generic identifications are not beyon

Of the 21 genera named in the table 4 are represented to-day in the Atlantic Ocean, 2 of them only in the Atlantic; 9 are represented in the living Pacific fauna, 7 of them only in the Pacific; and 10 genera are so far as known extinct. Although further study may add to the list, its essential indications will not be changed. The upper Eocene fauna of St. Bartholomew contains representatives of 11 living genera of corals, and 7 of these are, according to our present knowledge, now confined to the Indo-Pacific region. Therefore its affinities are more with the Indo-Pacific fauna of to-day than with that of the Atlantic. The genera whose names are preceded by a degree mark $\left(^{\circ}\right)$ also occur in deposits of Oligocene age.

\section{UPPER OLIGOCENE FAUNAS.}

Although there is much similarity in the upper Oligocene faunas, there are at least four recognizable horizons at which they occur in the southeastern United States. These are, named in stratigraphically ascending order, as follows: (1) Basal part of the Chattahoochee formation, in the reefs near Bainbridge, Ga.; (2) the silex bed of the Tampa formation, near Tampa, Fla., and at numerous localities in Florida and southern Georgia; (3) the Chipola marl member of the Alum Bluff formation; (4) the Oak Grove sand member of the Alum Bluff formation. Although the descriptions of these faunas are not quite complete, their essential characteristics have been ascertained. The following is a list of the coral genera:

Coral genera represented in the upper Oligocene deposits of Georgia and Florida.

\begin{tabular}{|c|c|c|c|c|c|c|c|}
\hline Genus. & $\begin{array}{c}\text { Basal } \\
\text { Chatta- } \\
\text { hoochee. }\end{array}$ & $\begin{array}{c}\text { Silex bed, } \\
\text { Tampa. }\end{array}$ & $\begin{array}{l}\text { Chipola } \\
\text { marl. }\end{array}$ & $\begin{array}{l}\text { Oak } \\
\text { Grove } \\
\text { sand. }\end{array}$ & Atlantic. & Pacific. & Extinct. \\
\hline 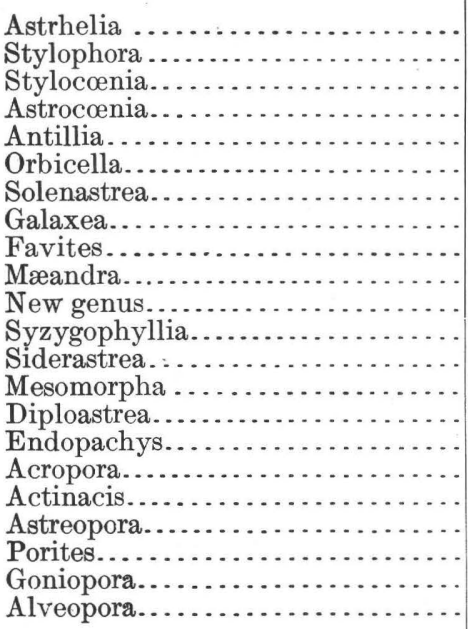 & 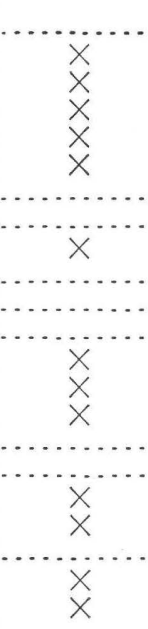 & 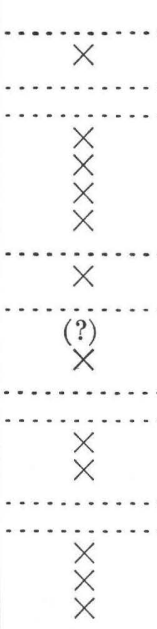 & 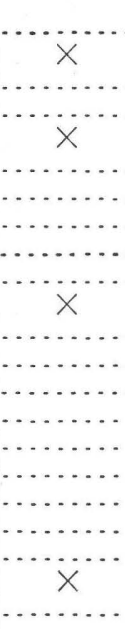 & 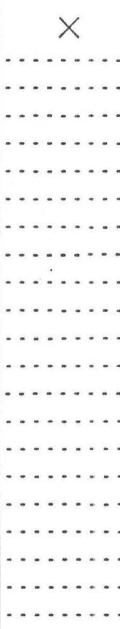 & 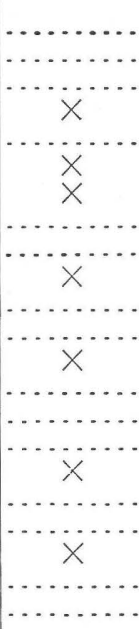 & $\begin{array}{l}x \\
x \\
x \\
x \\
x \\
x \\
x \\
x \\
x \\
x\end{array}$ & 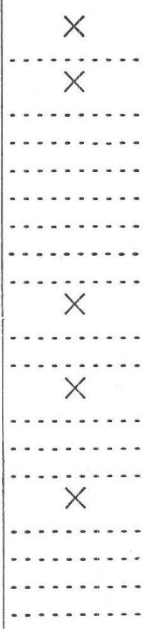 \\
\hline Total (22 genera). . . . . . . . . & 13 & 13 & 4 & 1 & 7 & 16 & 5 \\
\hline
\end{tabular}

$30830^{\circ}-17-24$ 
Of 13 genera represented in the basal Chattahoochee, 2 occur in the living faunas of both the Atlantic and the Indo-Pacific, 7 occur only in the Indo-Pacific, 1 only in the Atlantic, and 3 are extinct. The silex bed of Tampa contains 13 genera, 7 of which are at present confined to the Indo-Pacific, 6 are common to the Atlantic and Indo-Pacific, and none is extinct. The Chipola marl contains 4 genera, 3 of which persist in the Indo-Pacific but are not known in the Atlantic, and 1 is extinct. Only 1 genus, Astrhelia, has been found in the Oak Grove sand. It is represented in the lower Miocene of Maryland, but is now extinct. Tropical marine temperatures prevailed as far north as southern Georgia throughout the deposition of the Chattahoochee and Tampa formations, but during the period when the upper beds of the Alum Bluff formation were being laid down the waters cooled and living upper Oligocene coral reefs vanished from Georgia and Florida. The cooler Miocene epoch followed, and it was succeeded by the warm Pliocene epoch, during which reef corals flourished in southern Florida, but, as will later be mede clear, they represent a different fauna, for during the Miocene every coral of Pacific facies had disappeared, and the Pliocene fauna is of purely Atlantic affinities.

The West Indian and Central American upper Oligocene faunas represent several different horizons. (See references to my papers, p. 362.) One of the faunas, that at the base of the "marl formation" of Antigua (the Antigua formation of J. W. Spencer), is almost identical with that at the base of the Chattahoochee formation near Bainbridge, Ga. Beds representing the same horizon are exposed 4 miles west of Lares, Porto Rico ; and beds representing the same or nearly the same horizon occur at the base of the bluff at Crocus Bay, on the north side of the island of Anguilla. The higher beds in the Crocus Bay exposures seem to correspond stratigraphically with the Emperador limestone of Panama. The fauna of Bowden, Jamaica, is nearly related to this higher fauna but may be somewhat younger. The following table presents the list of genera for Antigua, Anguilla, Empire (Panama), and Bowden (Jamaica).

Genera of corals in the upper Oligocene of Antigua, Anguilla, Empire (Panama), and Bowden (Jamaica). [Genera whose names are followed by (L) occur also 4 miles west of Lares, Porto Rico.]

\begin{tabular}{|c|c|c|c|c|c|c|c|}
\hline Genus. & Antigua. & Anguilla. & $\begin{array}{l}\text { Empire, } \\
\text { Panama. }\end{array}$ & $\begin{array}{l}\text { Bowden; } \\
\text { Jamaica. }\end{array}$ & Atlantic. & Pacific. & Extinct. \\
\hline$\cdots \ldots \ldots \ldots \ldots$ & & & & & & & \\
\hline Placotrochus.. & & & & & & & \\
\hline Sphenotrochus... & & & & & & & 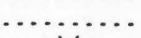 \\
\hline (n.................. & & & & & & & \\
\hline$\ldots \ldots \ldots \ldots \ldots \ldots$ & & & $\cdot$ & & & & \\
\hline$\ldots \ldots \ldots \ldots \ldots$ & & & > & $x$ & & & ... \\
\hline$\ldots \ldots \ldots \ldots \ldots$ & & & & & & & $\cdots \cdot$ \\
\hline 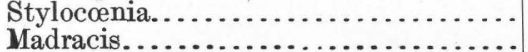 & & & & & & & \\
\hline 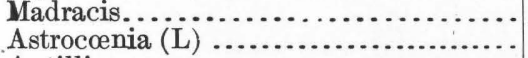 & & & & & & & $\cdots$ \\
\hline 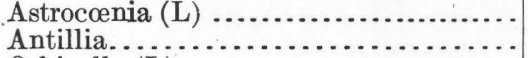 & $x$ & & & & & & \\
\hline lla $(\mathrm{L})$ & 分 & X & $x$ & & , & & \\
\hline a........... & & & $\ldots .$. & & $\hat{x}$ & 人 & ... \\
\hline (n. & & & & & & & y \\
\hline (n)........... & X & & $\cdots$ & & & & $\ldots$. \\
\hline a......... & & & $x$ & & & $x$ & $\ldots \ldots \ldots$ \\
\hline ma....... & & & $\cdots$ & & & & \\
\hline lia........ & & & $\cdots$ & $x$ & $\cdots$ & & $x$ \\
\hline $\begin{array}{l}\text { ophyllia..... } \\
\text { odra }(L) \ldots . . .\end{array}$ & & & $\cdots$ & & & & $x$ \\
\hline $\begin{array}{l}\text { dra }(\mathrm{L}) \ldots . . \\
\text { cina.......... }\end{array}$ & & & $\cdots$ & - & & X & $\ldots \ldots$ \\
\hline yllia............ & X & & $\cdots$ & & & & …. \\
\hline $\begin{array}{l}\text { phyllia............ } \\
\text { a }(\mathrm{L}) \ldots \ldots \ldots \ldots .\end{array}$ & & & & $x$ & & x & ..... \\
\hline$a(\mathrm{~L}) \ldots \ldots \ldots \ldots$ & & & & & & & \\
\hline s...... & $\begin{array}{l}x \\
x\end{array}$ & $\cdot$ & & & $\cdots$ & & $\cdots$ \\
\hline s. ........ & $x$ & $\cdots$ & & & & & \\
\hline$\ldots$ & $x$ & & . & & & $\hat{x}$ & \\
\hline astrea $(\mathrm{L})$.. & $x$ & & $\cdots$ & $x$ & $x$ & $x$ & $\cdots$ \\
\hline rea....... & & & & & & x & \\
\hline (I)............ & & & $x$ & & & $x$ & $\cdots$ \\
\hline $\begin{array}{l}\text { Astreopora (L) } \ldots \ldots \ldots \ldots \ldots \ldots \ldots \ldots \ldots \\
\text { Porites }\end{array}$ & & $\cdots \cdot$ & $\begin{array}{l}x \\
x\end{array}$ & & & & $\cdots$ \\
\hline $\begin{array}{l}\text { Porites. } \\
\text { Goniopora }(\mathrm{L}) \quad \ldots \ldots \\
\end{array}$ & x & $\begin{array}{l}x \\
x\end{array}$ & & $x$ & & $\begin{array}{l}x \\
x\end{array}$ & $\ldots .$. \\
\hline Iveopora.. & & & $\cdots$ & & & & $\ldots \ldots \ldots$ \\
\hline Total (34 genera) . & 24 & 10 & 8 & 14 & 12 & $22+? 1$ & 7 \\
\hline
\end{tabular}


The Antiguan fauna contains 24 genera, of which only 5 are extinct; of the 19 genera represented by living species 2 are now confined to the Atlantic, 5 are represented in both the Atlantic and Pacific, and 12 (50 per cent) are at present confined to the Pacific. The fauna is predominantly Pacific. Of the 9 genera on Anguilla 3 are at present confined to the Pacific. Of the 8 genera from Empire, Panama, 5 are represented by living species only in the Pacific. . Of the 14 genera represented at Bowden, Jamaica, 2 are extinct, 2 are at present confined to the Atlantic, 5 are common to the Atlantic and Pacifie, and 6 (if Placocyathus is included) are confined to the Pacific. Stephanocœnia is found at Bowden and appears to have been collected in place. It is also Pleistocene and Recent in the West Indies. The living Stephanoconia intersepta (Esper) is the type of the genus.

Because of the known presence of species of Lepidocyclina (identified by J. A. Cushman) in the base of the Chattahoochee formation near Bainbridge, Ga., in the Antigua formation in Antigua, in the fossil reefs of Anguilla, and in the Emperador limestone of Panama, most paleontologists will agree as to the Oligocene age of these deposits, and as the beds exposed 4 miles west of Lares, Porto Rico (the Pepino formation of Hill) contain essentially the same coral fauna as the Antigua formation, their Oligocene age will probably be conceded.

It should be stated here that H. Douville ${ }^{1}$ refers Lepidocyclina canellei Lemoine and R. Douvillé and L. chaperi Lemoine and R. Douvillé, both of which occur in the Culebra formation of the Canal Zone, to the Aquitanian, which he considers to be Miocene. The Culebra formation immediately underlies the Emperador limestone, in which the principal reef-coral fauna of the Canal Zone is found in association with Lepidocyclina and other orbitoidal Foraminifera. The larger Foraminifera of the Canal Zone are described in a paper, now awaiting publication, by Dr. Jos. A. Cushman, who has almost completed descriptions of the species of Lepidocyclina and Orthophragmina from the southeastern United States and the West Indies.

Regarding the age of the formations belonging to the Apalachicola group but higher than the

1 Les orbitoïdes de l'île de Trinité: Paris Acad. sci. Compt. rend., vol. 161, pp. 87-92, 1915; Les couches à orbitoïdes de l'isthme de Panama: Soc. géol. France Compt. rend. for Dec. 20, 1915, pp. 129-130.
Chattahoochee formation in Georgia and Florida there is controversy, and the controversy extends to the age of the marl at Bowden, Jamaica, some paleontologists contending that these formations are of Oligocene age, others that they are of Miocene age. Berry ${ }^{2}$ has recently discussed this subject, and his concluding remarks are as follows:

There is thus no structural (diastrophic) evidence for drawing the Oligocene-Miocene boundary between the Chattahoochee and Alum Bluff formations, nor is there any floral or faunal evidence for such a boundary. There is such a break between the Vicksburg and Apalachicola groups, and the Alum Bluff is separated by an erosion unconformity from the overlying Choctawhatchee Miocene. It rests with invertebrate paleontology to determine whether or not the whole of the Apalachicola group shall be considered Miocene. Whatever may be the final verdict, it remains true that the flora preserved at Alum Bluff records the last phase of sedimentation before the area emerged from the sea and that the most profound break in Tertiary sedimentation in the southeastern United States, emphasized equally by epeirogenic, "faunal, and floral changes, was at the end of Apalachicola time - that is, it is represented by the unconformity at the top of the Alum Bluff formation.

The Apalachicola group has an impressive unity for those who have had extensive field experience in studying it, and they will not readily sanction its dismemberment. Out of 13 genera, the Bowden marl contains 6 of IndoPacific affinities (Placocyathus, Placotrochus, Stylophora, Antillia, Syzygophyllia, and Goniopora) and 2 (Thysanus and Teleiophyllia) that are extinct. As the affinities of this coral fauna are predominantly Indo-Pacific, I am inclined to the opinion that it corresponds stratigraphically to the upper part of the Apalachicola group and is older than the Chesapeake group (Miocene) of the United States.

Apalachicolan time was terminated by the notable geologic events mentioned in the quotation from Berry. ${ }^{3}$ These events led to a severing of the waters of the Atlantic from those of the Pacific by the establishment of land connection between North and South America. It seems that the extinction of the coral genera of purely Pacific affinities was effected by causes not understood but in some way related to these events, for these genera

2 Berry, E. W. The physical conditions and age indicated by the flora of the Alum Bluff formation: U. S. Geol. Survey Prof. Paper 98, pp. 44-46, 1916 (Prof. Paper 98-E).

3 For additional discussion of the subject see Vaughan, T. W., A contribution to the geologic history of the Floridian Plateau: Carnegie Inst. Washington Pub. 133; pp. 153-157, 1910; Vaughan, T. W., and Cooke, C. W., Correlation of the Hawthorn formation: Washington Acad. Sci. Jour., vol. 4, pp. 250-253, 1914. 
are not present in the next younger important eoral fauna of the southeastern United States.

\section{MIOCENE FAUNA.}

The Miocene coral fauna of the eastern and southeastern United States is poor both in genera and in species. ${ }^{1}$ The genera are Paracyathus, Astrhelia, Astrangia, Septastrea, and a species described by Gregory ${ }^{2}$ under the name Prionastræa vaughani, which perhaps should be referred to the genus Favites-a total of five genera. The marine waters of the Miocene in the southeastern United States, as Dall and others have pointed out, were cold as compared with the earlier Apalachicola and the later Pliocene sea, and Berry ${ }^{3}$ has recently reconsidered this subject. Although the waters appear not to have been so cold as was formerly believed, they were too cold for reef corals, and such organisms disappeared from the eastern and southern parts of the continent during Miocene time.

\section{PLIOCENE FAUNA.}

Pliocene time was initiated by a recurrence of warm-water conditions, and with the change in climate a fairly rich reef-coral fauna established itself in Florida as far north as latitude $27^{\circ}$. It is especially well exposed within the area underlain by the Caloosahatchee marl. The following are the genera:

Corals in the Caloosahatchee marl (Pliocene).

\begin{tabular}{|c|c|c|c|}
\hline Genus. & Atlantic. & Pacific. & $\begin{array}{c}\text { Carrizo } \\
\text { Creek, } \\
\text { Cal. }\end{array}$ \\
\hline 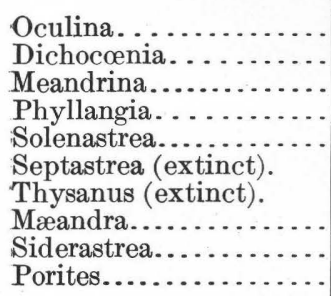 & $\begin{array}{l}\stackrel{x}{x} \\
\stackrel{x}{x} \\
\stackrel{x}{x}\end{array}$ & $\begin{array}{c}\times \\
\cdots \cdots \\
\cdots \\
x \\
x \\
x\end{array}$ & x \\
\hline Total (10 genera). & 8 & 6 & 5 \\
\hline
\end{tabular}

${ }^{1}$ See Vaughan, T. W., Maryland Geol. Survey, Miocene, pp. 438-447, pls. 122-129, 1904

2 Gregory, J. W., New species of Cladophyllia, Prionastræa, and Stylina: Annals and Mag. Nat. Hist., 7th ser., vol. 4, p. 458, figs. $2 a, 2 b, 1899$.

3 Berry, E. W., The physical conditions indicated by the flora of the Calvert formation: U. S. Geol. Survey Prof. Paper 98, pp. 61-73, 1916 (Prof. Paper 98-F).
The foregoing table shows that of 10 genera represented in the Caloosahatchee marl 2 are extinct, 8 persist in the living Antillean fauna, and 6 are common to the Atlantic and the Indo-Pacific. The species belonging to the 8 genera that are also Recent are either living or, with one exception, so near species at present living on the Florida and Bahama reefs that specific discrimination is difficult or doubtful. All the purely Indo-Pacific elements are lacking in this fauna, which, except for one of the two extinct genera (Septastrea) is typically Antillean. Of the 6 genera represented in the fauna of Carrizo Creek 5 also occur in the Caloosahatchee fauna, and all 6 are present in the living Antillean fauna.

\section{PLEISTOCENE AND RECENT FAUNAS.}

A list of the genera of corals at present living in the shoal waters of the West Indies, Florida, and Central America is given on page 361. Until now it has not been possible to distinguish between the Pleistocene and Recent faunas of the region, as all definitely identified Pleistocene species are also found living in the same region.

\section{SUMMARY.}

The data presented in the foregoing discussion show:

1. That during Eocene, lower Oligocene, and upper Oligocene time the coral faunas of the southeastern United States and the West Indies comprised three elements- $(a)$ genera now extinct; $(b)$ Recent genera which are now living only in the Indo-Pacific region; and (c) genera which persist in the western Atlantic Ocean, the Gulf of Mexico, and the Caribbean Sea, and some of which are also present in the living Indo-Pacific faunas.

2. That the sharp differentiation between the Atlantic and Pacific faunas took place between the end of Apalachicola time and the beginning of Pliocene time, and that since Pliocene time there has been only subordinate modification of the Atlantic fauna. ${ }^{4}$

4 R. A. Daly's suggestion that this differentiation was due to lowerin of marine temperature during Pleistocene glaciation (Am. Acad. Arts and Sci. Proc., vol. 5, pp. 169-170, 1915) can not be true, for the differentiation had taken place before Pliocene time. 
3. That this differentiation was in some way related to diastrophic and other geologic events which occurred during Miocene time. The causes of the extinction of the Pacific elements are unknown. The problem is rendered more difficult because the reef corals of the Atlantic and Indo-Pacific conform to the same ecologic principles. ${ }^{1}$ Mayer says in his paper on Torres Straits: "We must conclude that 'corals are corals,' and their behavior is essentially alike both in Florida and Australia."

4. That the systematic affinities of the fauna of Carrizo Creek are with the Caloosahatchee Pliocene of Florida and the Pleistocene and living faunas of the Antilles.

\section{GEOLOGIC AGE OF THE FAUNA OF CARRIZO CREEK.}

From statements already made it is obvious that there has been great uncertainty as to the geologic age of the fauna of Carrizo Creek. At first it was thought to be probably Cretaceous, later it was considered lower Miocene, after that it was referred to the upper Miocene, and the latest opinion is that it is Pliocene.

The following statement and list are quoted from Kew: ${ }^{2}$

The age of the Carrizo formation ${ }^{3}$ has not been definitely determined. Dr. Arnold ${ }^{4}$ referred to it as equivalent to the upper Miocene or lower Pliocene Etchegoin formation of the San Joaquin Valley of middle California, correlating by means of the pectens. The echinoderm fauna seems to indicate a comparatively late age, as several of the forms are very closely related to the species living in the Gulf of California at the present time, and these species are presumed to change relatively rapidly. Whether this seemingly slow development is due to comparative isolation in a warm-water area is as yet not known. These questions can not be answered definitely until the fauna has been compared carefully with the Recent life from the Gulf of California.

1 See references to my papers on p. 360. Also Mayer, A. G., An expedition to the coral reefs of Torres Straits: Pop. Sci, Monthly, vol 85, pp. 209-231, 1914; Ecology of the Murray Island coral reef: Nat. Acad. Sci. Proc., vol. 1, pp. 211-214, 1915; Carnegie Inst. Washington Pub. 213, pp. 1 et seq., 1917.

2 Kew, W. S. W., Tertiary echinoids of the Carrizo Creek region, in the Colorado Desert: California Univ. Dept. Geology Bull., vol. 8, pp. 46, $47,1914$.

${ }^{3}$ See footnote on p. 355 .

4 Science, new ser., vol. 19, p. 503, 1904; U. S. Geol. Survey Prof. Paper 47, p. 21, 1906; U. S. Geol. Survey Bull. 396, p. 44, 1909.
An approximate list of the fauna of the Carrizo formation, so far as determined, is as follows:

\begin{tabular}{|c|c|c|c|}
\hline & \multirow{2}{*}{$\begin{array}{c}\text { Lower } \\
\text { division, } \\
\text { all } \\
\text { localities. }\end{array}$} & \multicolumn{2}{|c|}{ Upper division. } \\
\hline & & $\begin{array}{l}\text { Carrizo } \\
\text { Valley. }\end{array}$ & $\begin{array}{c}\text { Yuha } \\
\text { Buttes. }\end{array}$ \\
\hline PELECYPODA. & & & \\
\hline Anomia subcosta Conrad.... & & & X \\
\hline 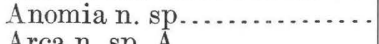 & & & x \\
\hline $\begin{array}{l}\text { Arca n. sp. } \bar{A} \cdots \ldots \\
\text { Arca n. sp. B }\end{array}$ & & $x$ & $\ldots \ldots$ \\
\hline $\begin{array}{l}\text { Arca n. sp. B..................... } \\
\text { Cardium aff. C. quadrigena- }\end{array}$ & & $\cdots \cdots \cdots$ & $\cdots \cdots$ \\
\hline rium Conrad. ............. & & & $\ldots \ldots$ \\
\hline Crassatellites sp . . . . . . . . . . & & & $\ldots \ldots$ \\
\hline Divaricata eburnea Reeve... & & $\cdots$ & $\ldots \ldots .$. \\
\hline 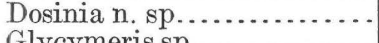 & & $\ldots \ldots \ldots$ & $\ldots \ldots$. \\
\hline Glycymeris sp....................... & X & $\cdots \ldots$ & $\ldots \ldots$ \\
\hline Hinnites gigantea $n$. var.... & $x$ & $\cdots$ & $\ldots \ldots$ \\
\hline Lithodomus sp.................. & $x$ & $\cdots$ & $\ldots \ldots$ \\
\hline Metis alta Conrad............... & $x$ & $\cdots$ & $\ldots \ldots$ \\
\hline Ostrea heermani Conrad..... & $x$ & & $\ldots \ldots$ \\
\hline Ostrea vespertina Conrad... . & $x$ & x & $x$ \\
\hline Panope generosa Gould ...... . & $\widehat{\hat{y}}$ & & $\ldots \ldots$ \\
\hline Pecten carrizoensis Arnold.. & $x$ & $x$ & $\ldots \ldots$ \\
\hline Pecten subnodosus n. var... & & & \\
\hline Pecten circularis n. var..... & $x$ & $x$ & x \\
\hline Pecten deserti Conrad ...... & $x$ & & $\ldots \ldots$ \\
\hline $\begin{array}{l}\text { Pecten cerrosensis var. men- } \\
\text { denhalli Arnold........... }\end{array}$ & $x$ & & 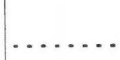 \\
\hline Pecten keepi Arnold........ . & & $\cdots$ & $\ldots \ldots$ \\
\hline Pecten n. sp.......... & & $\cdots$ & $\cdots \ldots \ldots$ \\
\hline $\begin{array}{l}\text { Phacoides cf. P. sanctæcru- } \\
\text { cis Arnold................... }\end{array}$ & & & \\
\hline 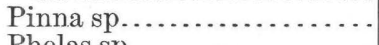 & & & $\ldots \ldots$ \\
\hline 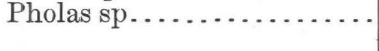 & & $\cdots$ & $\cdots \ldots \ldots$ \\
\hline GASTROPODA. & & & \\
\hline Architectonica sp......... & X & $\ldots$ & $\ldots \ldots \ldots$ \\
\hline Cancellaria sp. A......... & $x$ & ... & $\ldots \ldots$ \\
\hline Cancellaria sp. B......... & $x$ & $\ldots$. & $\ldots \ldots$ \\
\hline 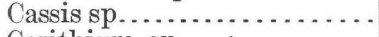 & $x$ & $\ldots \ldots$ & $\ldots \ldots$ \\
\hline Cerithium sp............ & $x$ & $\ldots \ldots$. & $\ldots \ldots$ \\
\hline 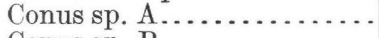 & $x$ & $\ldots \ldots$ & $\ldots \ldots$ \\
\hline 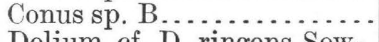 & X & ........ & $\ldots \ldots$ \\
\hline $\begin{array}{l}\text { Dolium cf. D. ringens Sow- } \\
\text { erby............................ }\end{array}$ & $x$ & & $\cdots$ \\
\hline $\begin{array}{l}\text { Neverita cf. N. recluziana } \\
\text { Petit................. }\end{array}$ & & & \\
\hline Oliva cf. $\mathrm{O}$. porphyria Lin- & $x$ & & $\cdots$ \\
\hline 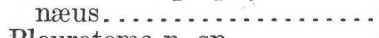 & $x$ & & $\ldots \ldots$ \\
\hline Pleurotoma n. sp........... & X & $\cdots$ & $\ldots \ldots$ \\
\hline Terebra sp. A............... & $x$ & $\cdots$ & $\ldots \ldots$ \\
\hline Terebra sp. B.............. & $y$ & $x$ & $\ldots \ldots$ \\
\hline Turritella n. sp............... & $x$ & & $\cdots \ldots$ \\
\hline ECHINODERMATA. & & & \\
\hline Encope tenuis n. sp........ & $x$ & & $\ldots \ldots$ \\
\hline 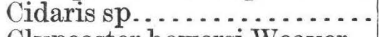 & $\lambda$ & $\cdots$ & $\ldots \ldots$ \\
\hline Clypeaster bowersi Weaver. . & X & $\ldots \ldots \ldots$ & $\ldots \ldots$ \\
\hline Clypeaster carrizoensis n. sp. & & $\ldots \ldots$ & $\ldots \ldots$ \\
\hline Clypeaster deserti n. sp...... & & $\ldots \ldots$ & $\ldots \ldots$ \\
\hline Hipponoë californica n. sp .. & & & $\ldots \ldots \ldots$ \\
\hline
\end{tabular}


Regarding the echinoids $\mathrm{Kew}^{1}$ says that "Clypeaster bowersi Weaver resembles Echinanthus (Clypeaster?) testudinarius Gray, living in the Gulf of California," and that "The Recent Hipponoë depressa A. Agassiz found in the Gulf of California and on the west coast of Lower California is closely allied to Hipponö̈ catifornica."

Nomland ${ }^{2}$ refers the coralliferous beds on Carrizo Creek to the Pliocene, and he says in a letter to me dated June 13, 1916:

In regard to the Pliocene age of the Carrizo Creek beds there is only very little evidence. Dr. Arnold correlated the Etchegoin ${ }^{3}$ with the Carrizo Creek beds and thought
Edwards and Haime. I am confident that the species does not belong to Madrepora. The specific affinities of the Carrizo Creek corals are discussed in detail after the descriptions in the systematic part of this paper. The Carrizo Creek species are so near species belonging to the same genera in the Pliocene Caloosahatchee marl of Florida and in the Pleistocene and living reefs of Florida and West Indies that it seems to me they can scarcely be so old as Miocene; lower Pliocene appears to be the maximum age which may be assigned to the fauna.

Corals from Carrizo Creek, Cal.

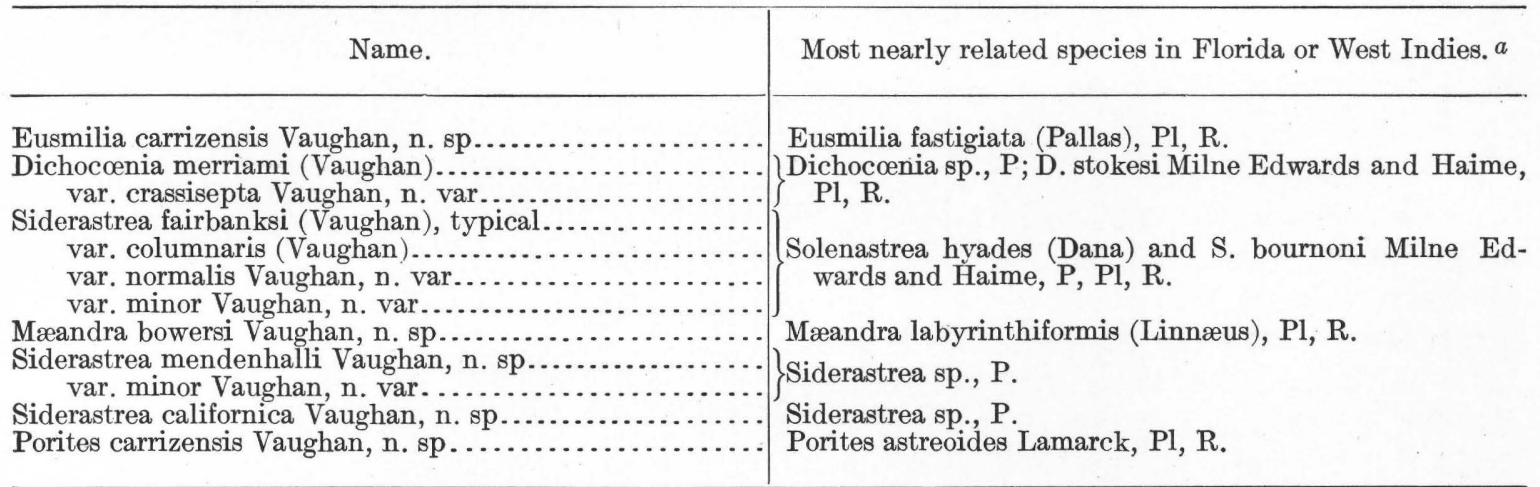

a P, Pliocene; Pl, Pleistocene; R, Recent.

both of Miocene age. His correlation was based almost entirely on Pecten deserti Conrad. Later we found, as shown by land vertebrates, that the Etchegoin formation and, as we thought, also the Carrizo Creek beds are of Pliocene age. I have recently collected from the Etchegoin a large number of specimens of the form called Pecten deserti by Arnold. I find, however, that this is undoubtedly different from the species occurring in the Carrizo Creek beds. The Pelecypoda and Gastropoda which have heretofore been specifically listed may be either Miocene or Pliocene.

In addition to the species and varieties listed in the accompanying table Nomland describes and figures a coral from Carrizo Creek under the name Madripora solida. I have not seen this species and am not sure as to its generic relations. I suppose "Madripora" is intended to be Madrepora, type species Madrepora oculata Linnæus = Amphelia oculata (Linnæus) Milne

\footnotetext{
1 Kew, W. S. W., op. cit., pp. 50, 51.

${ }_{2}$ Nomland, J. O., Corals from the Cretaceous and Tertiary of California and Oregon: California Univ. Dept. Geology Bull., vol. 9, p. $60,1916$.

${ }^{3}$ Arnold, Ralph, Paleontology of the Coalinga district, Fresno and Kings counties, Cal.: U. S. Geol. Survey Bull. 396, p. 44, 1909.
}

BEARING OF THE FAUNA OF CARRIZO CREEK ON A POSSIBLE POST-OLIGOCENE INTEROCEANIC CONNECTION.

That there was interoceanic connection across parts of Central America during upper Oligocene time and that this connection was terminated in Miocene time is generally admitted. The extinction of Pacific faunal elements in the Gulf of Mexico, the Caribbean Sea, and the western Atlantic Ocean has been discussed and summarized on page 366 . Was there interoceanic connection during upper Miocene or Pliocene time after the sharp differentiation of the Caribbean and Mexican Gulf faunas from the Indo-Pacific faunas, thereby permitting interoceanic faunal migration? The discovery of a reef-coral fauna of purely Floridian and Caribbean facies at the head of the Gulf of California strongly suggests, if it is not positive proof, that the western Atlantic fauna extended from the Atlantic into the Pacific after the faunal differentiation had 
taken place. It is well known that the living reef-coral fauna on the Pacific side of Central America is depauperate in comparison with that on the Atlantic side. Greater vigor may account for the dominance of the migrant fauna over the Pacific fauna, which was finally suppressed, or geologic or other ecologic conditions that are not yet understood may have excluded the Pacific fauna from the head of the Gulf of California, while they permitted the migration of the Atlantic fauna into that area.

That the suggested interoceanic connection existed can scarcely be doubted. To locate it, in the present state of meager knowledge of the areal and stratigraphic geology of Central America, is not possible. Perhaps it was across the Isthmus of Tehuantepec. The problem awaits future investigation.

\section{CONCLUSIONS.}

The foregoing discussion may be summarized as follows:

1. The Carrizo Creek reef-coral fauna is Atlantic, not Pacific, in its affinities.

2. During Eocene and Oligocene time there was connection between the Atlantic and Pacific oceans across Central America, and there was no sharp differentiation between the Atlantic and Pacific faunas.

3. Upper Oligocene (Apalachicolan) time was closed by diastrophic and other geologic events of profound importance, which separated the Atlantic from the Pacific Ocean by forming a land area extending from North to South America. During Miocene time sharp differentiation between the Atlantic and Pacific faunas took place, largely by the extinction of the Pacific elements in the Atlantic area.

4. The Pliocene coral fauna of Florida is purely Atlantic in its affinities, and since Pliocene time there has been only minor modification of the coral fauna in the western Atlantic, the Gulf of Mexico, and the Caribbean Sea.

5. The fauna of Carrizo Creek is related to Pliocene and post-Pliocene faunas of Florida and the West Indies and can scarcely be older than lower Pliocene.

6. Subsequent to the differentiation between the Atlantic and the Pacific faunas there was in upper Miocene or Pliocene time inter- oceanic connection, which permitted the Atlantic fauna to extend into the Gulf of California and up to its head, and conditions not yet understood excluded the Pacific fauna from the area.

7. The locus of the inferred interoceanic connection is not known. It was probably in the region of the Isthmus of Tehuantepec, or farther southeast.

\section{SYSTEMATIC DISCUSSION OF THE FAUNA.}

\section{MADREPORARIA IMPERFORATA.}

Family EUSMILIID五 Verrill.

Genus EUSMILIA Milne Edwards and Haime.

1848. Eusmilia Milne Edwards and Haime, Compt. Rend., vol. 27, p. 467.

Type species: Madrepora fastigiata Pallas.

\section{Eusmilia carrizensis Vaughan, n. sp.}

Plate XCV, figures 1, 1a.

Corallum cespitose, similar in growth form to Eusmilia fastigiata. Single branches as much as 13.5 by 15 millimeters in diameter. Costæ distinct but not very prominent, alternately larger and smaller, corresponding to the septa.

In a small corallite 8.5 millimeters in diameter there are about 16 septa which extend to the columella; alternating with these are shorter and much thinner septa. In places three smaller septa may be seen in a loculus between two large septa. In a spảce 5.5 millimeters long, measured on a chord, there are 7 septa.

Columella trabecular, well developed.

Locality: Barrett Canyon, Carrizo Creek. Imperial County, Cal.

Affinities: This species is about as close to Eusmilia fastigiata (Pallas), of the Floridian and Antillean region, as Dichocœnia merriami is to D. stokesi. The difference between the two is that E. fastigiata has more crowded septa, about ten in 5.5 millimeters, whereas E. carrizensis has seven in the same space. The growth form, the size of the branches, and the columellar character are the same in both.

Illustrations of $E$. fastigiata are given on Plate XCV, figures 2, 2a. 
Genus DICHOCGNIA Milne Edwards and Haime.

1848. Dichocœnia Milne Eelwards and Haime, Compt. Rend., vol. 27, p. 469.

1857. Dichocœnia Milne Edwards and Haime, Histoire naturelle des coralliaires, vol. 2, p. 199 (type species figured, Pl. DI, figs. 10a, 10b).

Type species: Astrea porcata Lamarck, on authority of Milne Edwards and Haime.

It is my belief that Madrepora porcata Esper $^{1}$ is not this species, for Esper says: "Die Fläche ist ganz eben, und die Sterne ohne einen erhoheten Rand zu haben, eingesenkt." His figures suggest a coral similar to Favia puteolina (Dana) or Favia danæ Verrill. The Dichoconia porcata of Milne Edwards and Haime differs from $D$. stokesi principally by the possession of an "épithèque extrêmement mince et peu distincte." It seems to me probable that their D. porcata and D. stokesi are the same species, especially as I have never seen a specimen of a living species of Dichocœnia from the Pacific or Indian Ocean, and none are reported by Studer, Stanley Gardiner, Bedot, Von Marenzeller, Gravier, or Matthai. According to the present available information, the genus is found living only in the western Atlantic Ocean, the Gulf of Mexico, and the Caribbean Sea. The Dichocœnia uva of Milne Edwards and Haime is based on Esper's Madrepora uva, ${ }^{2}$ from the China Sea. This appears to be a species of Favia and is probably the same as Favia speciosa (Dana). From the description, it seems to me that Dichoccenia stellaris Milne Edwards and Haime is a varietal form of $D$. stokesi. A positive opinion can be based only upon a restudy of Milne Edwards and Haime's original specimens and types, but the suggestion is warranted that their $D$. porcata, D. stokesi, and D. stellaris all belong to the same species, and that both Madrepora porcata and M. uva of Esper belong to the genus Favia and not to Dichocœnia.

\section{Dichocœenia merriami (Vaughan) Vaughan.}

Plate XCIV, figures 1, 1a.

1900. Favia merriami Vaughan, U. S. Geol. Survey Mon. 39 , p. 142 , pl. 15 , figs. 5 , 5a-5c.

1906. Favia merriami Vaughan, in Arnold, Tertiary and Quaternary pectens of California: U. S. Geol. Survey Prof. Paper 47, p. 22.

1916. Favia merriami Nomland, California Univ. Dept. Geology Bull., vol. 9, p. 60.

1 Esper, E. J. C., Fortsetzungen der Pflanzenthiere, pl. 71, 1795.

2 Idem, pl. 43.
The original description of this species is as follows:

Corallum subplane or rounded above, massive. The species is based on three broken specimens, nearly of a size. *** The condition of preservation of the material is, as is unfortunately too often the case with the fossil species, not satisfactory. The calices are elliptical. The following gives measurements of several:

\begin{tabular}{|c|c|c|c|c|}
\hline & 1 & 2 & 3 & 4 \\
\hline $\begin{array}{l}\text { Greater diameter of calice..... } \\
\text { Lesser diameter of calice. }\end{array}$ & $\begin{array}{r}M m .5 \\
6.5 \\
4.5\end{array}$ & $\begin{array}{r}M m .5 \\
6.5 \\
2.5\end{array}$ & $\begin{array}{r}M m .5 \\
5.5 \\
4.5\end{array}$ & $\begin{array}{r}M m . \\
5.5 \\
4.5\end{array}$ \\
\hline
\end{tabular}

Some calices are almost circular, with a diameter of 4.5 millimeters. The calices are from 2 to 3 millimeters apart. The walls between the corallites are thick ( 2 to 3 millimeters) and usually compact; are evidently formed of fused costæ; correspondingly, sometimes the costæ can in the sections be traced some distance across the area between the corallites. On the upper surface of the corallum costæ correspond to all septa and extend from one calice to the next. They are low, sometimes flattened above or slightly acute, minutely granulated, straight or somewhat flexuous. Septa, in calice No. 1 of the above table, about 33 in number. The number for the fully grown calices seems to vary between 30 and 36; younger calices may have only 24. The various cycles are not distinctly indicated. There is usually a fairly regular alternation in size of the septa, the larger ones reaching the columella. They are thick, thicker at the wall, and have paliform thickenings on their inner ends. Faces granulate. Dissepiments very well developed, thin, 1.5 to 2.5 millimeters apart in the longitudinal section of the corallites. The character of the septal margins is not shown by the material at hand. The calicular fossæ are extremely shallow or are almost superficial. The columella is false, large, well developed.

The large suite of specimens collected by Mendenhall and Bowers makes a fuller description of the species possible.

The corallum is of massive growth form, upper surface regularly domed or undulate. The following are the dimensions of four specimens:

Dimensions of Dichoconia merriami, in millimeters.

\begin{tabular}{|c|c|c|c|c|c|c|}
\hline & 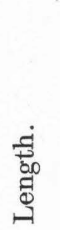 & 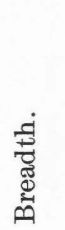 & $\begin{array}{l}\stackrel{+}{0} \\
\stackrel{0}{0} \\
\stackrel{0}{=}\end{array}$ & 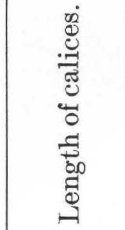 & 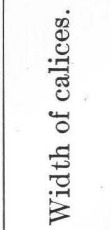 & 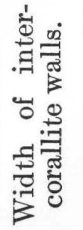 \\
\hline $1 \ldots \ldots$ & 133 & 107 & 76 & 6-17 & $3.5-6$ & $1-4$ \\
\hline $2^{a} \ldots \ldots$ & 151 & 111 & 97 & 5. 5-13 & $3.5-6.5$ & $1-3$ \\
\hline $3 \ldots \ldots$ & 147 & 116 & 85 & 5. $5-10$ & $4-5.5$ & $1-5$ \\
\hline $4 \ldots \ldots . .$. & 147 & 121 & 83 & $4.5-12.5$ & $3-7$ & $1-4$ \\
\hline
\end{tabular}


The size of the calices is given in the table. The shortest calices have been recently cut off by fission from the parent corallite and are subcircular or elliptical in form. In the longest calices there are usually three centers which have not been isolated by complete fission. The distance apart ranges from the thickness of a dividing septum to about 5 millimeters. The least width of the corallite wall as given in the table is for calices which are completely separated and have developed intercorallite walls.

The calicular edges are somewhat elevated, the outer surface of the corallites sloping or falling almost perpendicularly to the bottom of the intercorallite depressions. The maximum amount of exsertness on these specimens is about 1 millimeter. Costæ correspond to the septa but usually are not notably prominent.

The septa and columella are better shown in the specimen represented by Plate XCIV, figures 1, 1a, described below.

Corallum subhemispherical, 57 by 67 millimeters in diameter and 39 millimeters tall. Corallites project as much as 2.5 millimeters; distance between calicular margins from 1 to 3 millimeters; free limbs with distinct subequal or slightly alternating costæ that correspond to all septa. Length of calices from 5 to 13.5 millimeters; width from 3 to 6.5 millimeters. Septa in a young corallite 4 millimeters in diameter about 18 , of which 8 reach the columella; in a corallite 5.5 by 8.5 millimeters in diameter, there are 43 septa, of which 12 are appreciably larger than the others and reach the columella, and 8 others are nearly as large; alternating with the 20 larger septa are smaller septa, and there are a few rudimentaries. Another corallite 10.5 millimeters long has 42 septa, of which about half reach the columella, and there is an equal number of smaller septa. In places three sizes of septa are recognizable, and here and there are septal groups of threes. Septal margins apparently entire; paliform lobes commonly present. Septal faces granulate.

Columella trabecular, well developed; in some elongate calices an axial lamella is present, but this is derived from a septum.

Locality: Barrett Canyon, Carrizo Creek, Imperial County, Cal.
Affinities: This species is very close to Dichoccenia stokesi Milne Edwards and Haime, which is found on the living reefs in the Bahamas, the West Indies, and Florida, and occurs fossil in Santo Domingo, where it has been known as Barysmilia intermedia and Dichocenia tuberosa, both proposed by Duncan. ${ }^{1}$ A closely related species is found in the Pliocene Caloosahatchee marl of Florida, but descriptions and figures of it have not been published. There are in the United States National Museum large suites of D. stokesi. In growth form, general aspect, the size and distribution of the calices, and the character of its costæ it is like D. merriami, but the columella of $D$. stokesi seems to be less well developed, and a calice 4.5 by 7 millimeters in diameter has 42 septa, one 5 millimeters in diameter has 34 septa, and one 4 millimeters in diameter has 24 septa. Therefore D. stokesi seems to have a weaker columella and somewhat more numerous septa than D. merriami, but the differences are so slight that the California specimens should perhaps be referred to the same species as the one to which the Floridian and West Indian specimens belong. To facilitate comparison of the two species, figures of $D$. stokesi are given in Plate XCIV, figures 2, 2a.

Dichocœnia merriami var. crassisepta Vaughan, n. var. Plate XCIV, figures 3, 3a.

This variant has thick, strongly exsert principal septa with corresponding strong costæ and thin intermediate septa with corresponding thin costæ. The differential characters are shown in the figures.

Locality: Barrett Canyon, Carrizo Creek, Imperial County, Cal.

\section{Family ORBICELLID无 Vaughan.}

\section{Genus SOLENASTREA Milne Edwards and Haime.}

1848. Solenastrea Milne Edwards and Haime, Compt. Rend., vol. 27, p. 494.

1850. Solenastrea Milne Edwards and Haime, British fossil corals, Introduction, p. xl.

Type species: Astrea turonensis Michelin.

The following is the characterization of the genus published by Milne Edwards and Haime in 1850 :

Corallum forming in general a convex mass, of a light and cellular structure. Gemmation extra calicular. Co-

${ }^{1}$ London Geol. Soc. Quart. Jour., vol. 19, pp. 431, 432, 1863. 
rallites long, slender, and united by an exothecal structure, and not by costæ, which do not meet and are often rudimentary. Calices circular, with an exsert margin. Columella spongy, and in general small. Septa very thin; their margin denticulated. Dissepiments simple, numerous, and closely set.

Solenastrea and Cyphastrea were united by Duncan under the former name, the latter being reduced to subgeneric rank, ${ }^{1}$ and characterized as follows: "The generic characters are as in Solenastrea, but the septa are cribriform."

Leptastrea, Solenastrea, Cyphastrea, and Orbicella are closely related genera. The following paragraphs indicate what seem to me to be the differential characters.

Leptastrea Milne Edwards and Haime (type species, L. roissyana Milne Edwards and Haime), septa imperforate, corallites usually not joined by costæ, intercorallite tissue compact, its surface more or less granulate but not spinulose.

Solenastrea Milne Edwards and Haime (type species, Astrea turonensis Michelin), similar to Leptastrea, except that the corallites are separated by highly vesicular exotheca, unless crowded, when they may be separated by simple walls.

Cyphastrea Milne Edwards and Haime (type species, Astrea microphthalma Lamarck), similar to Solenastrea, except that the inner parts of many septa are cribriform, and the surface of the intercorallite tissue is spinulose.

Orbicella Dana (type species, Madrepora annularis Ellis and Solander), similar to $\mathrm{Cy}$ phastrea, except that the costæ are strongly developed and extend from one corallite to another.

I have been perplexed and have vacillated in my treatment of Solenastrea, sometimes referring it to the synonymy of Cyphastrea, sometimes to that of Orbicella. I am now retaining it as a valid genus for the following reasons: There is a group of species which is represented in the Recent and fossil faunas of Florida and the West Indies, and which shows constant characters. The group is well represented in the Tampa upper Oligocene, in the Caloosahatchee Pliocene, and in both the Pleistocene and living faunas. Except where the corallites are greatly crowded, they are separated by highly vesicular intercorallite tissue, the

7 Linnean Soc. London Jour., vol. 18, p. 107, 1884. upper surface of which is granulate and more or less costate but not spinulose. The costæ may or may not extend from one corallite to the next; if the corallites are close together they may meet, but if the corallites are distant they usually do not meet. The costæ where well developed have not along their summits dentations, as in Orbicella, nor small sharp spinules, as in Cyphastrea. Because of the constant differences between this group of species and other genera, and of the constant similarity within the group, apparently it should have generic recognition.

Unfortunately no specimens of the type species of Solenastrea are available to me for study; but to judge from Michelin's very good figures and from the description of Milne Edwards and Haime the foregoing statement applies to the characters of the genotype.

There are two species in the living West Indian fauna, both of which also occur in the Caloosahatchee Pliocene. One is Solenastrea hyades (Dana) (see Pl. XCVIII, all figures), which appears to be a synonym of Madrepora pleiades Ellis and Solander, and Solenastrea bournoni Milne-Edwards and Haime (see Pls. XCIX and C, all figures), of which the following species of Duchassaing and Michelotti are synonyms: Heliastræa abdita, Leptastræa caribæa, Cyphastræa carpinetti, Solenastræa micans, and Solenastræa ellisi. In S. hyades the members of the third cycle of septa fuse to the sides of the secondaries; in $S$. bournoni the inner ends of the tertiaries are free.

Solenastrea fairbanksi (Vaughan) Vaughan, typical.

Plate XCV, figures 3, 3a.

1900. Stephanoconia fairbanksi Vaughan, U. S. Geol. Survey Mon. 39, p. 151, pl. 17, figs. 11, 11a.

1906. Plesiastrea californica (nomen nudum) and Stephanocœnia fairbanksi Vaughan, in Arnold, Tertiary and Quaternary pectens of California: U. S. Geol. Survey Prof. Paper 47, p. 22.

1916. Stephanoconia fairbanksi Nomland, California Univ. Dept. Geology Bull., vol. 9, p. 60.

The original description of this species is in part as follows:

Form of corallum explanate or columnar. The specimens possessing the explanate method of growth may be considered the typical form; those with the columnar method of growth, S. fairbanksi var. columnaris var. nov. * * * The corallites are polygonal in form, usually hexagonal, and are joined directly by their walls or by very short costæ. The greater diameter of the corallites 
is very constantly 3.5 millimeters. Some corallites may be smaller and some slightly larger, but 3.5 millimeters is the usual diameter. The walls between two corallites on an unweathered surface or in a section are stout and usually solid; they are almost a millimeter thick. They are clearly pseudothecal. In places the corallites may be joined by very short costæ; then open vertical spaces may exist between the costæ. None of the specimens shows the upper edge of the wall in its original condition; therefore its ornamentation can not be described. The septa are in three complete cycles; the members of the first and second cycle fuse to the columella; those of the third cycle fuse to the sides of those of the second (?). (There is no way of differentiating the first from the second cycle.) They are thicker at the wall; their faces granulate. The character of the septal margins could not be studied. In the bestpreserved calices there appear to be pali before both the first and second cycles of septa. In the thin section both of these cycles of septa show thickenings on and near their inner ends corresponding in position to the apparent lobes on the septa. The calices are not preserved intact, but that 12 pali existed seems quite clear. Endotheca very well developed.

The original description needs modification in only one particular. The excellent suite of specimens obtained by Mendenhall and Bowers shows that the columella is trabecular and is not like that of the type species of Stephanocœnia (Madrepora intersepta Esper). The tertiary septa may or may not fuse to the sides of the secondaries; in the same calices some of the tertiaries are fused to the secondaries, and others have free inner margins.

As often happens when a new species is based on a singlespecimen, or only a few specimens, the type specimen of this species does not represent the usual character of the species. The type has an explanate mode of growth and crowded calices separated by narrow walls. Plate XCV, figure 3 , represents a typical specimen, one-half natural size: It is a pulvinate mass, 185 millimeters in diameter, and 68 millimeters thick. Plate $\mathrm{XCV}$, figure $3 \mathrm{a}$, represents a group of ealices, enlarged four times. Specimens such as this might be considered to represent a species distinct from those later described as the varieties normalis and minor, were not intergradation completely shown. Plate XCV, figures 4, 4a, gives two views of two calicular areas, each enlarged four times, on the same specimen, to show variation in the intercorallite walls. It appears that flattish colonies have crowded calices and that more or less hemispherical colonies have more distant calices.

Locality: Alverson Canyon, Carrizo Creek, Imperial County, Cal.
Solenastrea fairbanksi var. columnaris (Vaughan) Vaughan.

Plate XCVI, figures 1, 1a.

1900. Stephanocœnia fairbanksi var. columnaris Vaughan, U. S. Geol. Survey Mon. 39, p. 151, pl. 17, figs. 10, 10a.

1906. Stephanocœnia fairbanksi var. columnaris Vaughan, in Arnold, Tertiary and Quaternary pectens of California: U. S. Geol. Survey Prof. Paper 47, p. 22.

1916. Stephanoconia fairbanksi var. columnaris Nomland, California Univ. Dept. Geology Bull., vol. 9, p. 60 .

This variety differs from the typical form of the species in its columnar growth form and on the average its wider intercorallite areas. Both characters are shown in the figures.

Locality: Barrett Canyon, Carrizo Creek, Imperial County, Cal.

Solenastrea fairbanksi var. normalis Vaughan, n. var. Plate XCVI, figures 2, 2a, 2b, 2c; Plate XCVII, figures 1, 1 .

Most of the specimens of this variety are more or less hemispherical in form, and some attain a height of over 320 millimeters. The calicular characters are similar to those of the type specimen, except that the calicular margins are free, are slightly elevated, and may be as much as 2 millimeters apart. The costæ are distinct just below the calicular margins and may or may not meet on the intercorallite areas.

The range in diameter of the calices is from 2.5 to 3.5 millimeters, and the usual diameter is about 3 millimeters. This variety is discriminated from variety minor solely by its somewhat larger calices.

Localities: Alverson and Barrett canyons, Carrizo Creek, Imperial County, Cal.

Solenastrea fairbanksi var. minor Vaughan, n. var.

Plate XCVII, figures 2, 2a, 2b, 2c.

This variety differs from var. normatis by its smaller calices, which range from 1.5 to 2 millimeters in diameter. The inner ends of the tertiary septa are usually but not invariably free.

Locality: Alverson Canyon, Carrizo Creek, Imperial County, Cal.

Affinities of Solenastrea fairbanksi.

The illustrations of Solenastrea fairbanksi (Pl. XCV, figs. 3, 3a, 4, 4a; Pl. XCVI, all figures; and Pl. XCVII, all figures) may be 
compared with those of Solenastrea hyades (Dana) ( Pl. XCVIII, all figures), from the Pliocene Caloosahatchee marl of Florida, and with those of Solenastrea bournoni Milne Edwards and Haime (Pls. XCIX and C, all figures), which is now living in the West Indies and is a common species in the Caloosahatchee marl in Florida. Although these seem to be three well-marked species they are all closely related. The only species at present living in the Pacific which seems to me to belong systematically near this group of species is the coral from Wake Island to which Dana applied the name Astræa (Orbicella) pleiades and which was subsequently referred to Solenastrea by Verrill. (Dana's original specimen is No. 56, U. S. National Museum.) The Carrizo Creek specimens seem to me more closely related to the West Indian and Floridian specimens than to the form from Wake Island.

\section{Family FAVIIDE Gregory.}

\section{Genus M作ANDRA Oken.}

1815. Mæandra Oken, Lehrbuch der Naturgeschichte, Theil 3, Abt. 1, p. 70.

1902. Mæandra Verrill, Connecticut Acad. Arts and Sci. Trans., vol. 11, p. 66.

Type species: Madrepora labyrinthiformis Linnæus.

Mæandra bowersi Vaughan, n. sp.

Plate CI, figures 1, 1a.

1906. Diploria bowersi (nomen nudum) Vaughan, in Arnold, Quaternary pectens of California: U. S. Geol. Survey Prof. Paper 47, p. 22.

Corallum massive, subhemispherical. Type is a piece of a specimen whose diameter is about 70 millimeters; thickness about 37 millimeters.

Valleys relatively long and sinuous, 27 millimeters a common length; one exceeds 40 millimeters. A few circumscribed calices; one of these is about 6.5 millimeters in diameter. Width of valleys from 3.75 to 5.5 millimeters; usually about 4 millimeters; depth about 2 millimeters. Interserial colline with a shallow median depression; width of colline from 1.75 to 3.5 millimeters, usually 2.5 to 3 millimeters. Costæ well developed, correspond to all septa, distant, edges acute.

Septa, about 8 large ones, which reach the columella, to 1 centimeter; intermediate rudimentary septa variable in development, present in some places, absent in others.
Columella false, trabecular, fairly well developed.

Locality: Carrizo Creek, Imperial County, Cal. Stephen Bowers, collector.

Affinities: This species resembles Mrandra ("Diploria") labyrinthiformis, of Florida and the Antilles, but as the latter has about 12 principal septa to the centimeter, the two species can readily be distinguished. Plate CI, figure 2, presents a view of the valleys and collines of M. labyrinthiformis, twice natural size. The only known living species of Mæandra closely related to $M$. bowersi are in the West Indies, none at all being known in the modern Indo-Pacific faunas.

\section{MADREPORARIA FUNGIDA.}

Family AGARICIDD压 Verrill.

Genus SIDERASTREA De Blainville.

1830. Siderastrea De Blainville, Dictionnaire des sciences naturelles, vol. 60 , p. 75 .

Type species: Madrepora galaxea Ellis and Solander, $1786=$ Madrepora radians Pallas, 1766 .

Siderastrea mendenhalli Vaughan, n. sp.

Plate CI, figures 3, 3a, 4 .

The corallum is massive in form and has a flattish, rounded, or undulate upper surface. Some colonies attained a large size, as one specimen, not here described in detail, is 425 millimeters tall and over 440 millimeters in diameter on its upper surface.

Calices regularly polygonal or usually more or less deformed; diameter from 4 to 7 millimeters in those regularly polygonal; greater diameter of deformed calices as much as 7 millimeters; shorter diameter, from about 2.5 to 4 millimeters. The calicular cavities are rather shallow, the septal margins sloping gently from the narrow intercorallite wall to the bottom of the fossa.

Septa rather thin, crowded, usually in four complete cycles, the higher cycles grouped around the secondaries and tertiaries, as is usual in the genus. In many small calices the fourth cycle is incomplete in some systems; in large calices there are many members of the tifth cycle. Septal dentations rather fine, 13 or more on the large septa; about 15 dentations were counted on a septum 2 millimeters long. Synapticulæ highly developed, extending more than halfway from the wall to the columella; as many as 10 were counted between the wall and the columella in one interseptal loculus. 
Columella rather small, false; upper surface finely papillate.

Localities: Alverson and Barrett canyons, Carrizo Creek, Imperial County, Cal.

Affinities: This species belongs to the same group as Siderastrea siderea (Ellis and Solander), which is one of the common corals on the living reefs of Florida and the West Indies, but $S$. siderea has deeper, rather funnel-shaped calices. $S$. mendenhalli is close to a species found in the Caloosahatchee Pliocene of Florida but not yet described in print.

Siderastrea mendenhalli var. minor Vaughan, n. var. Plate CII, figure 1.

This variant is separated from the typical examples of the species by the smaller average size of its calices. There is intergradation, as the largest calices of the variant are 4 millimeters in diameter, but most of them are 3 millimeters or less in diameter. The fourth cycle of septa is usually incomplete in some of the systems.

Locality: Barrett Canyon, Carrizo Creek, Imperial County, Cal.

Siderastrea californica Vaughan, n. sp.

Plate CII, figures 2, 2a, 3, 4 .

1906. Siderastrea californica (nomen nudum) Vaughan, in Arnold, Tertiary and Quaternary pectens of California: U. S. Geol. Survey Prof. Paper 47, p. 22 .

Corallum of massive growth form; upper surface flattish or rounded. The largest specimen is 75 by 93 millimeters in diameter, and 105 millimeters tall.

Calices polygonal, not greatly deformed. Diameter of a large, fully grown one 4.5 millimeters; usual diameter of adult calices 4 millimeters; young calices 2.5 millimeters or less in diameter. Walls rather thick. Calicular cavities shallow, or superficial.

Septa relatively thick, especially the six primaries and either two or four secondaries. There are three complete cycles, and in many specimens the fourth cycle is complete in four of the six systems but not developed in two systems, one on each side of a primary. The septal trabeculæ are coarse and produce about 10 dentations on a primary septum. As there are fewer septal trabeculæ there are correspondingly fewer and coarser synapticulæ than in S. mendenhalli.
Columella false, papillary; becomes secondarily compacted so that it projects as a stout style in weathered calices.

Localities: Carrizo Creek (type, Stephen Bowers collector); Barrett Canyon, Carrizo Creek, Imperial County, Cal.

Affinities: This species can be readily distinguished from $S$. mendenhalli, if the material is well preserved, by its fewer, thicker, and more coarsely dentate septa. It is very close to an undescribed species from the Caloosahatchee Pliocene and is near $S$. radians (Pallas), which is widely distributed in the Pleistocene and Recent reef areas of the western Atlantic Ocean and the Caribbean Sea. Both Siderastrea mendenhalli and S. californica are represented by closely related, very similar, parallel species in the Pliocene Caloosahatchee marl of Florida. The septa of one of the Florida species are composed of small trabeculæ, which produce finely dentate septal margins and crowded, small synapticulæ, as in S. mendenhalli. The septa of the other species are composed of relatively coarse trabeculæ, and therefore the septal dentations are coarse and the synapticulæ are large, as in S. californica. Living species of Siderastrea occur in the Philippine Islands, the Indian Ocean, and the Red Sea, but the closest relatives of the Carrizo Creek species are in the Caloosahatchee Pliocene of Florida.

\section{MADREPORARIA PERFORATA.}

\section{Family PORITID丑 Dana. Genus PORITES Link.}

1807. Porites Link, Beschreibungen der Naturaliens Sammlungen, Rostock, p. 162.

Type species: Madrepora porites Pallas.

\section{Porites carrizensis Vaughan, n. sp.}

Plate CII, figures 5, 5a, 5b, 6, 6a.

Corallum of nodular or subhemispherical form with small gibbosities on its surface. The holotype is 62.5 by 71 millimeters in diameter and 49 millimeters thick; upper surface flattish.

Calices polygonal, small, 1.4 to 1.7 millimeters in diameter; excavated, but only moderately deep. Separating wall interrupted, zigzag, with coarse mural denticles. Its upper edge may be acute, or in places where the outer margins of the septa are wide it may be flat- 
tish, with a slight development of intercorallite reticulum, which is as much as 1 millimeter across.

Septa rather thick, 12 in number, arranged according to the poritid scheme; there is a solitary directive, four lateral pairs, and a directive triplet. The inner ends of the triplet are more or less free; as a rule the laterals of the group do not pronouncedly bend toward the included directive, but in some calices they seem to join it. In places there are suggestions of trident formation. There is some indefiniteness in the lateral pairs.

In places the septa are narrow in their upper parts; usually they are relatively wide over the wall, where their upper margins are flattened, while their inner margins fall steeply to the bottom of the calicular fossa. Normally there is a single, somewhat detached, rather coarse septal granule between the wall and the palar ring. The specimens show a fairly well developed outer synapticular ring, and the palar synapticular ring is usually complete. There is no conspicuous thickening of the horizontal structures, the skeletal elements being predominantly radial in the septa, and concentric in the wall and in the synapticular rings within the calices.

Pali are fairly well developed but appear variable in number, from 4 to 6 .

There is a weak columellar tubercle in some calices, but if it was present it has been broken in most of them.

Locality: Barrett Canyon, Carrizo Creek, Imperial County, Cal.

Affinities: This species has the same growth form, the same sized calices, the same mural characters, and the same kind of septal margins as $P$. astreoides Lamarck, of Florida and the West Indies. There is also a similar indefiniteness in' the septal grouping of each species. The calices of $P$. carrizensis seem shallower and the pali better developed than in $P$. astreoides, but the two are remarkably alike. 
PLATES XCIV-CII. 


\section{PLATE XCIV.}

Figures 1, 1a. Dichoccenia merriami (Vaughan) Vaughan from Carrizo Creek, Cal.

1. Corallum, natural size.

1a. Calices, $\times 3$.

Figures 2, 2a. Dichocœnia stokesi Milne Edwards and Haime. A recent specimen from Hog Island, Bahamas.. 371

2. Corallum, natural size.

2a. Calices, $\times 3$.

Figures 3, 3a. Dichoccenia merriami var. crassisepta Vaughan, n. var., from Carrizo Creek, Cal................

3. Corallum, natural size.

3a. Calices, $\times 3$.

378 

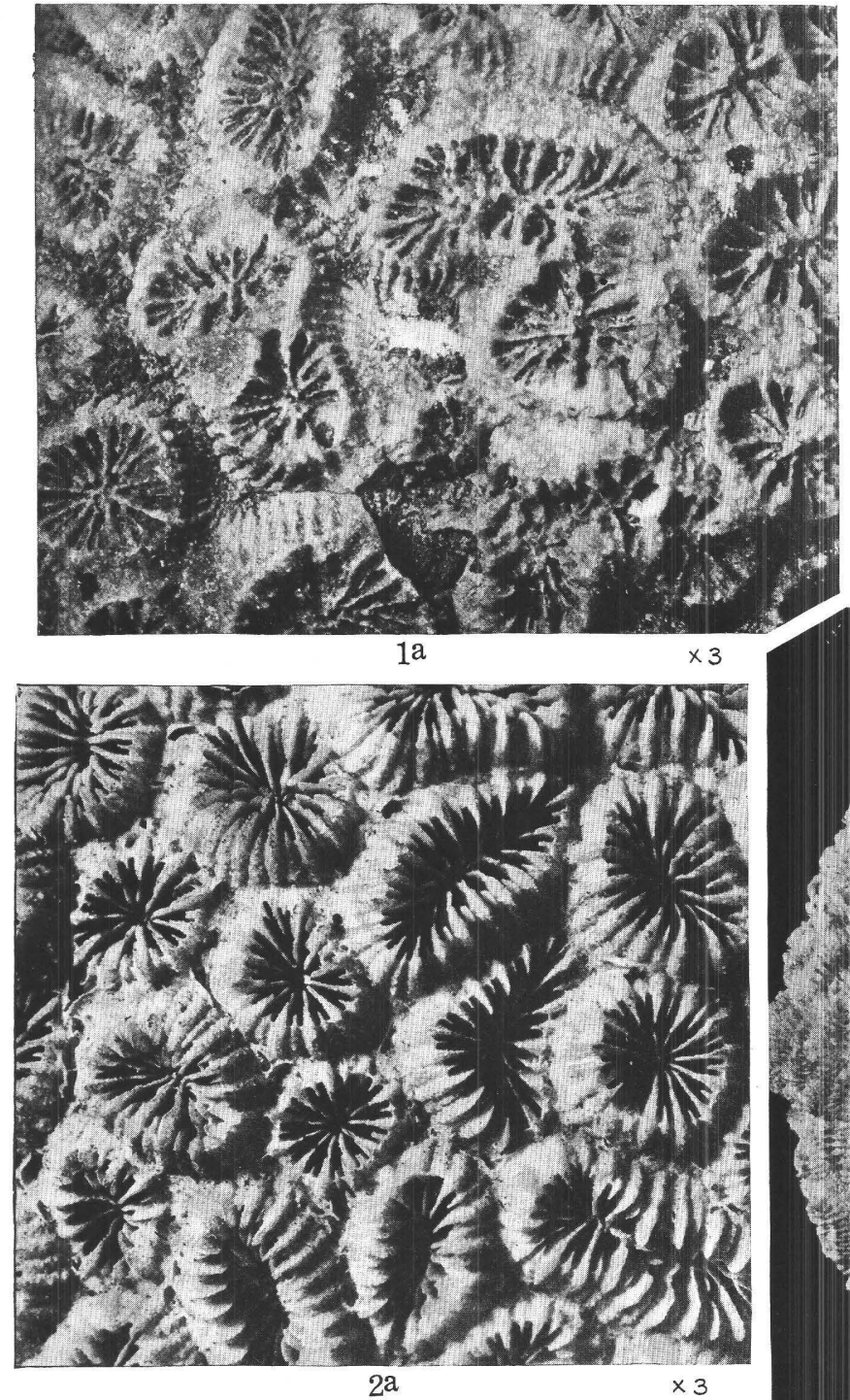

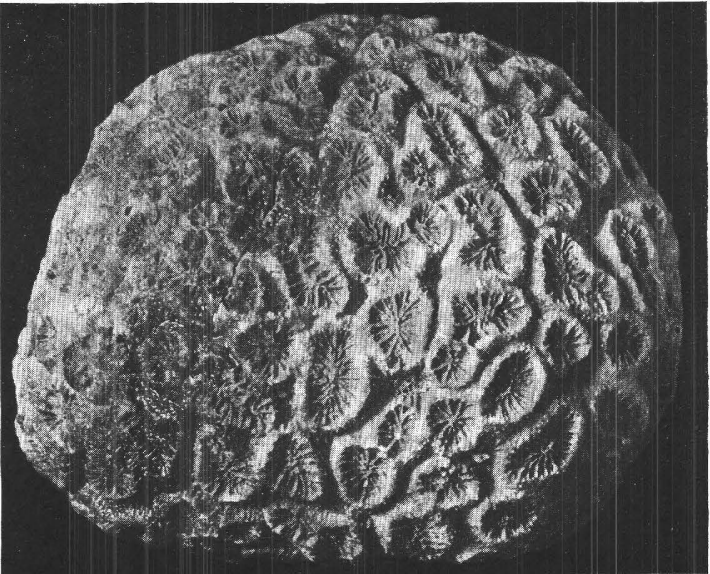

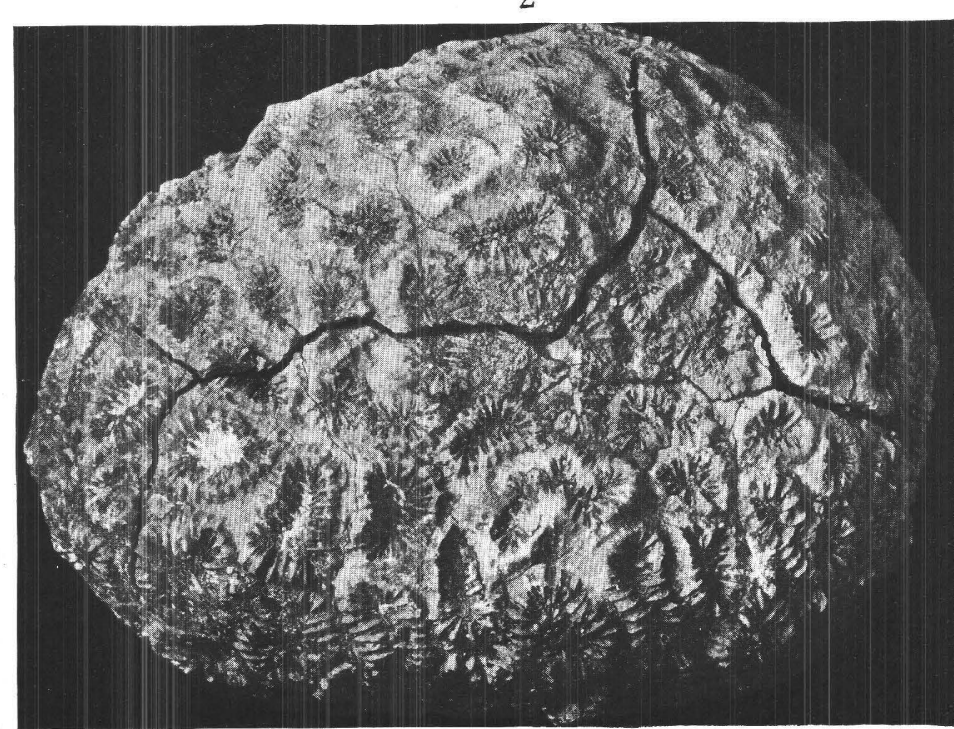

3 


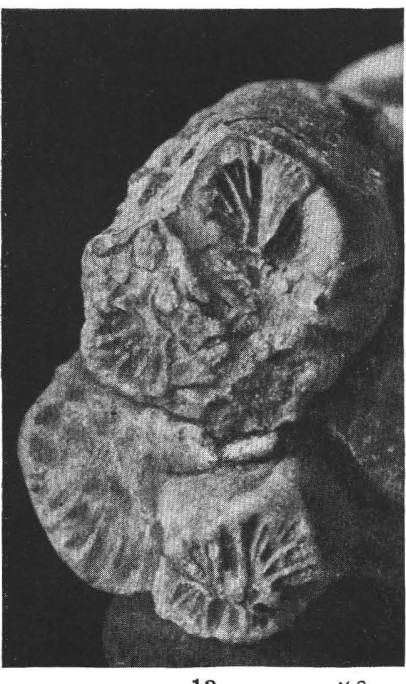

$1 \mathrm{a}$
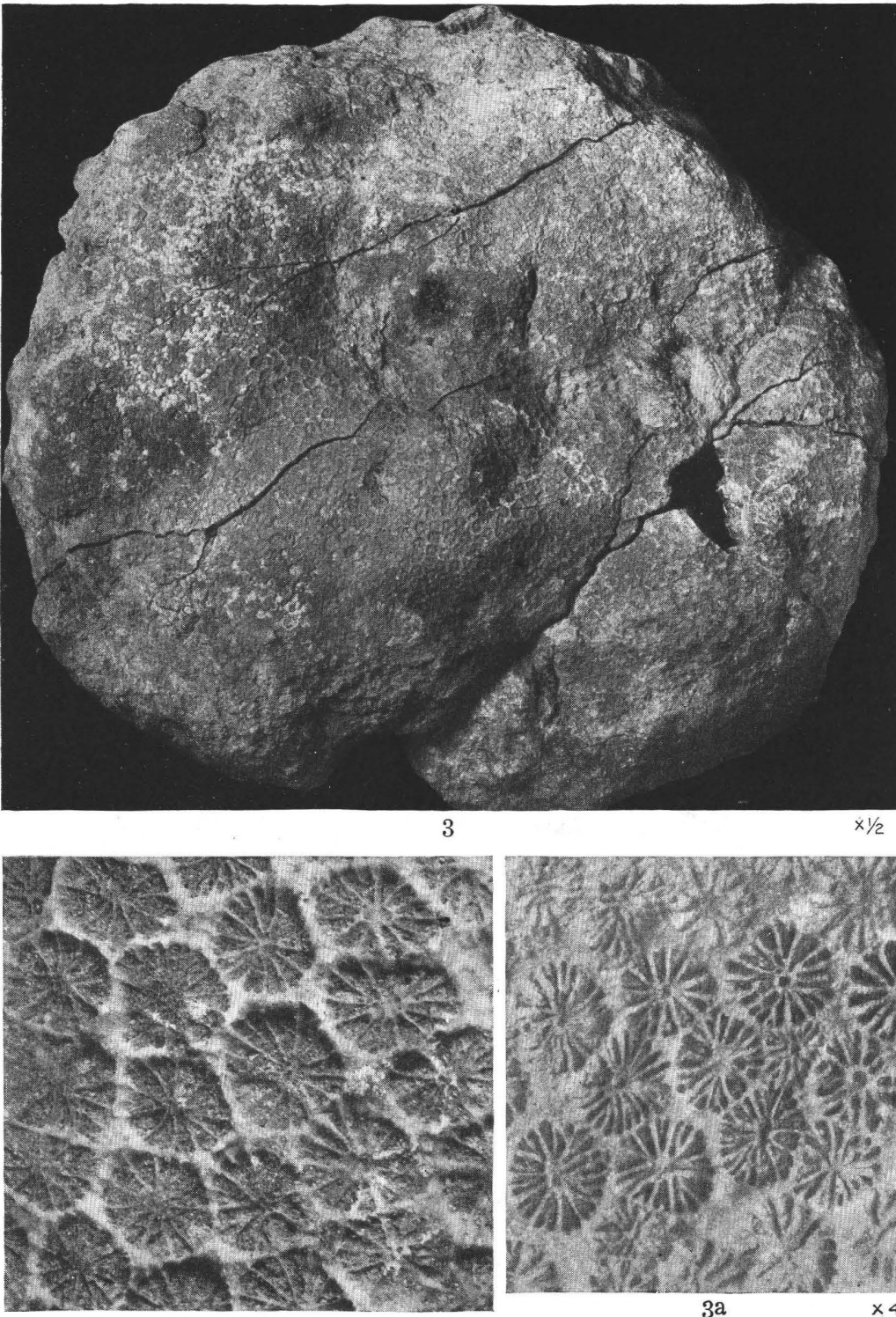

3

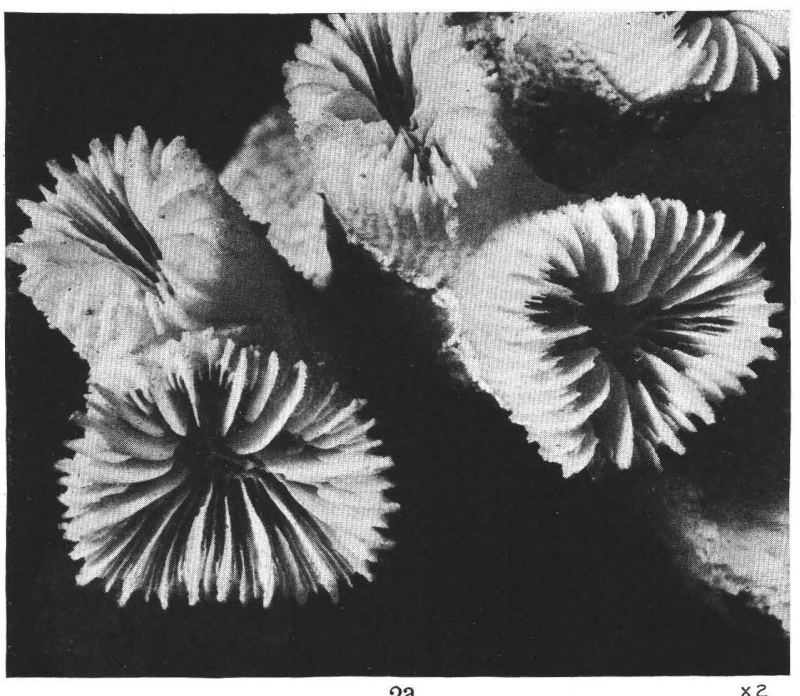

$2 \mathrm{a}$

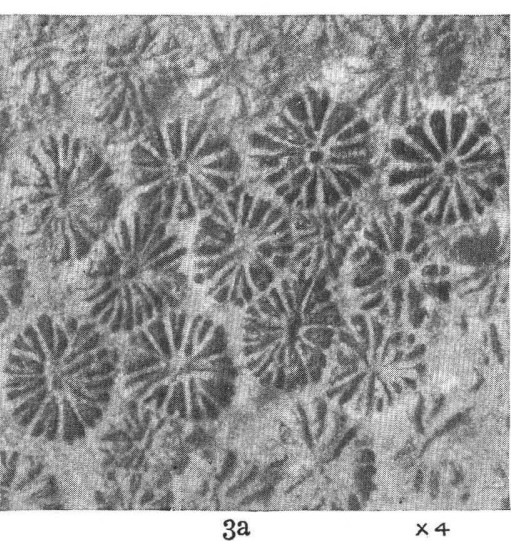

$3 a$

REEF CORALS.
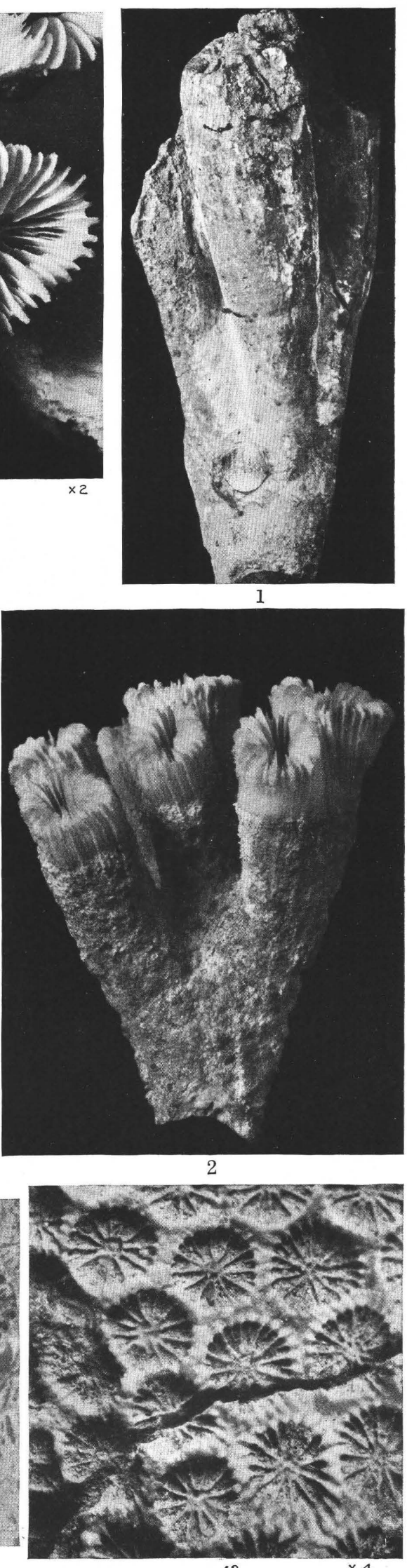

$4 a$ 


\section{PLATE XCV.}

Figures 1, 1a. Eusmitia carrizensis Vaughan, n. sp., from Carrizo Creek, Cal.

1. Corallum, natural size.

1a. Calicular ends of branches, $\times 2$.

Figures 2, 2a. Eusmilia fastigiata (Pallas), the type species of the genus, from Cocoanut Point, east side of

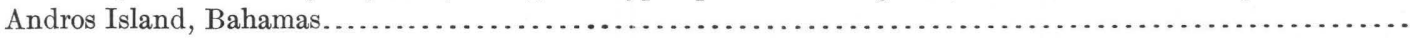

2. Corallum, natural size.

2a. Calices, $\times 2$.

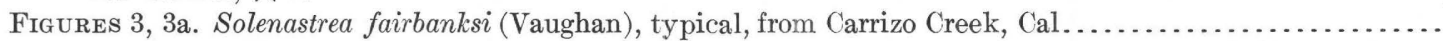

3, 3a. Two views of a specimen typical of the species; 3 , upper surface of corallum, one-half natural size; $3 a$, calices, $\times 4$.

Figures 4,4 a. Two views, each $\times 4$, of the calices of a specimen whose calicular characters are between those exhibited by typical specimens of Solenastrea fairbanksi and those of var. normalis. (See Pl. XCVI, figs. 2-2c, and Pl. XCVII, figs. 1, 1a). 


\section{PLATE XCVI.}

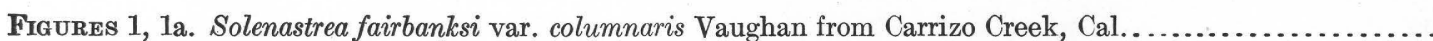

1. Side of specimen, natural size.

1a. Top of specimen, natural size.

Figures 2, 2a, 2b, 2c. Solenastrea fairbanksi var. normalis Vaughan, n. var., from Carrizo Creek, Cal. (See Pl. XCVII, figs $1,1 \mathrm{a}$.

2. Corallites as revealed by a fracture parallel to their longitudinal axes, natural size.

$2 \mathrm{a}, 2 \mathrm{~b}$. Two areas to show calicular characters, each $\times 4$

2c. Corallites as exposed by a fracture, $\times 4$.

380 

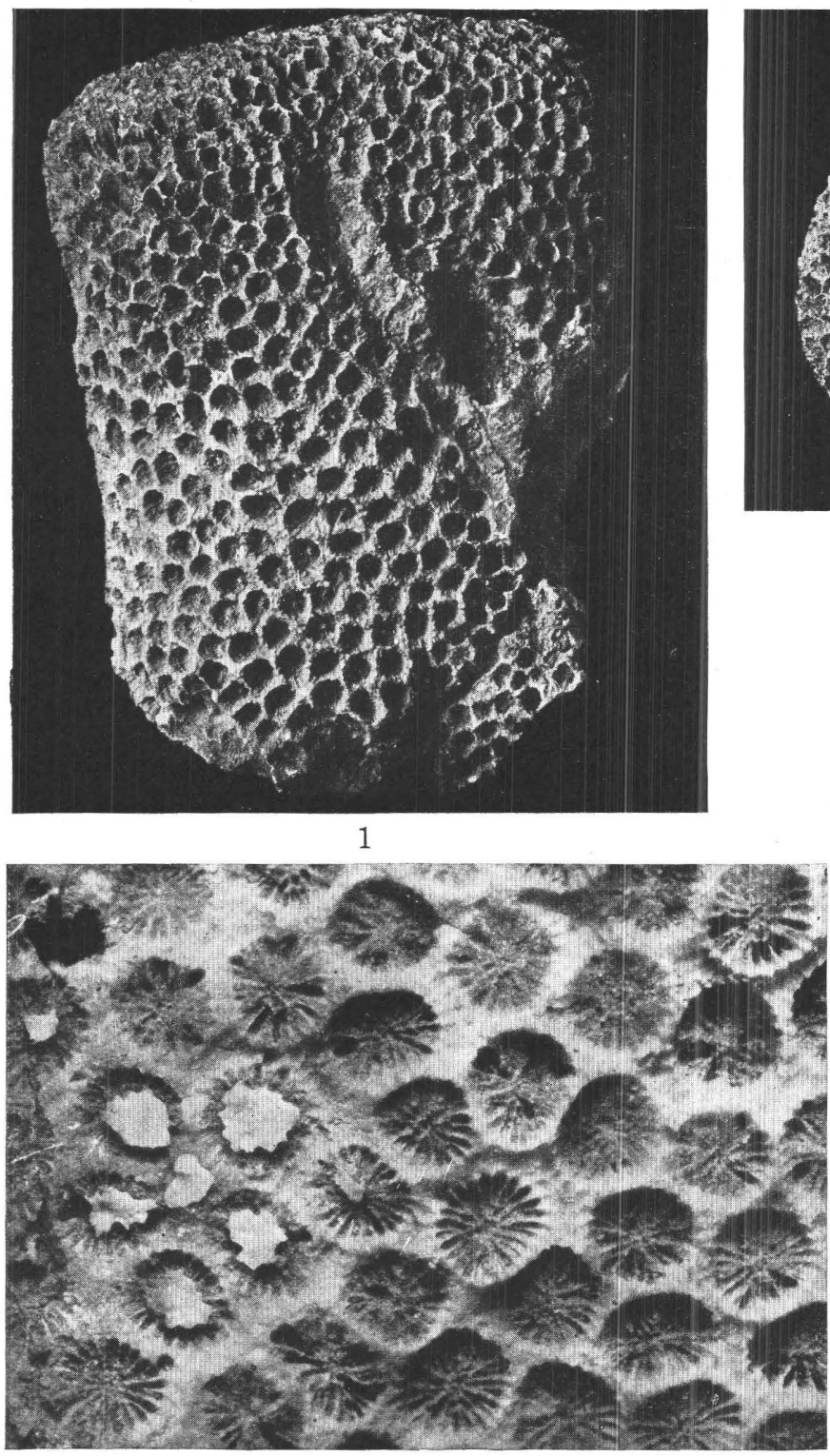

$2^{2}$

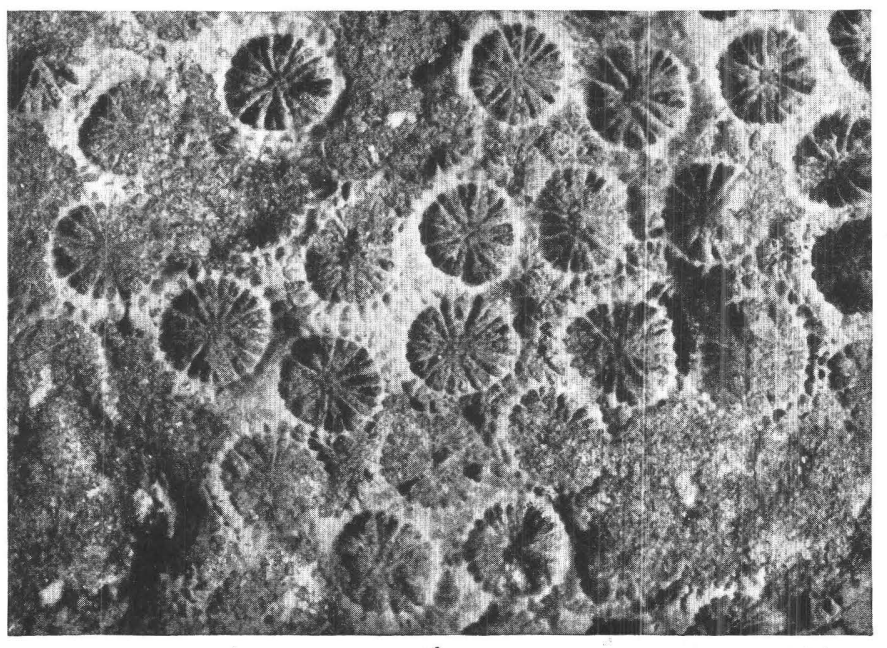

$2 \mathrm{~b}$

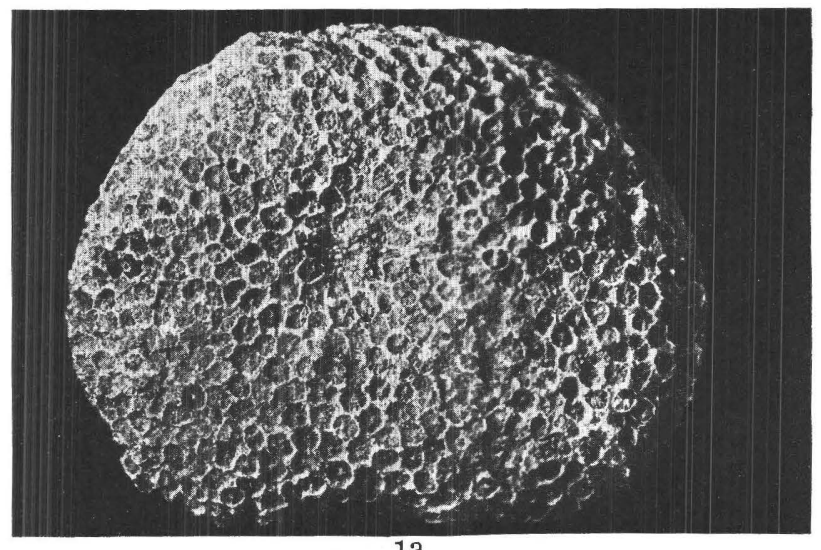

$1 \mathrm{a}$
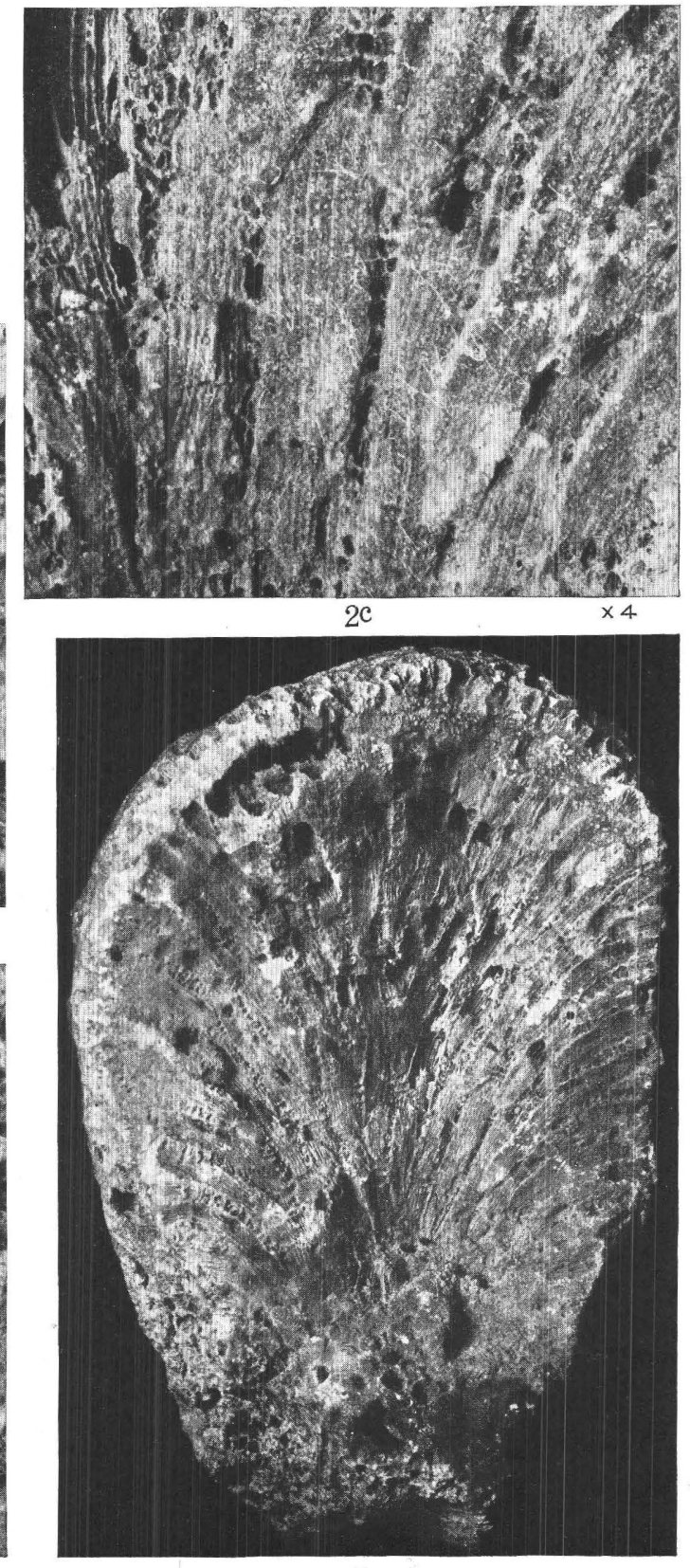

2

REEF CORALS. 
U. S. GEOLOGICAL SURVEY

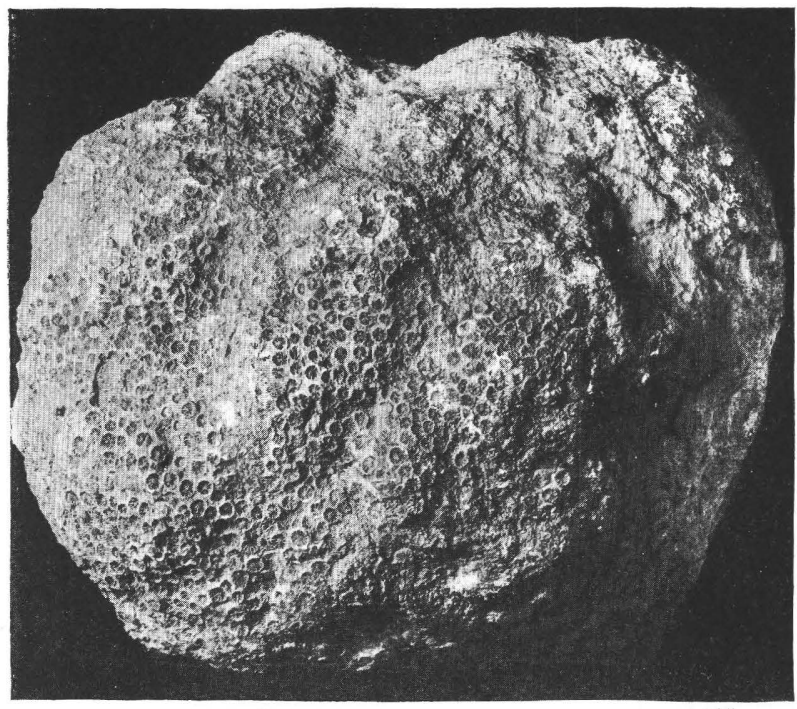

1

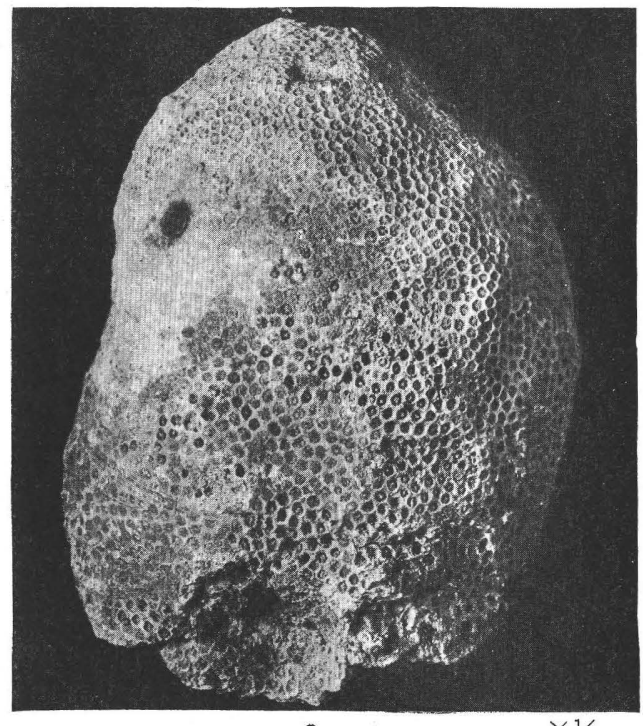

2

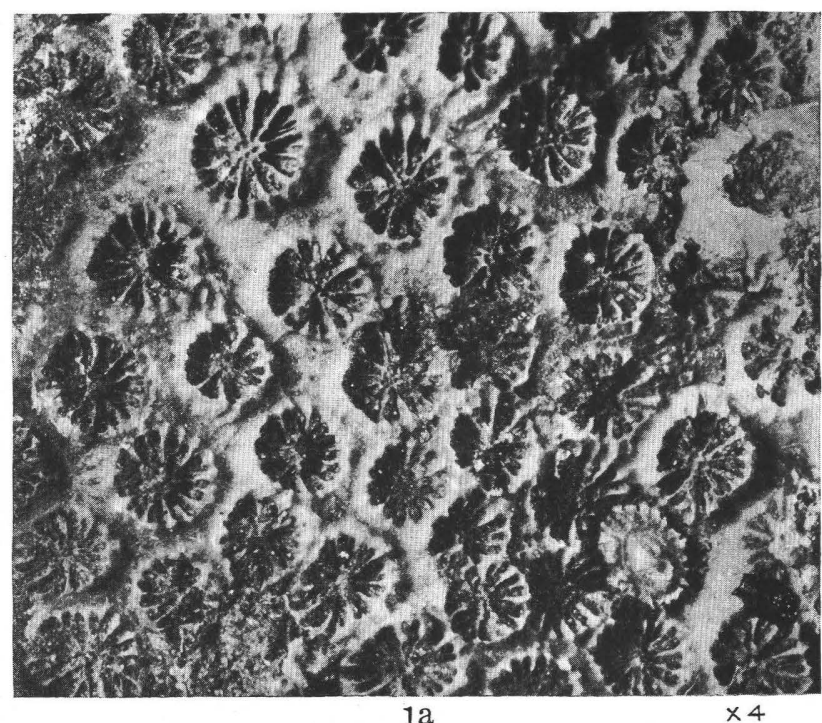

$1 \mathrm{a}$

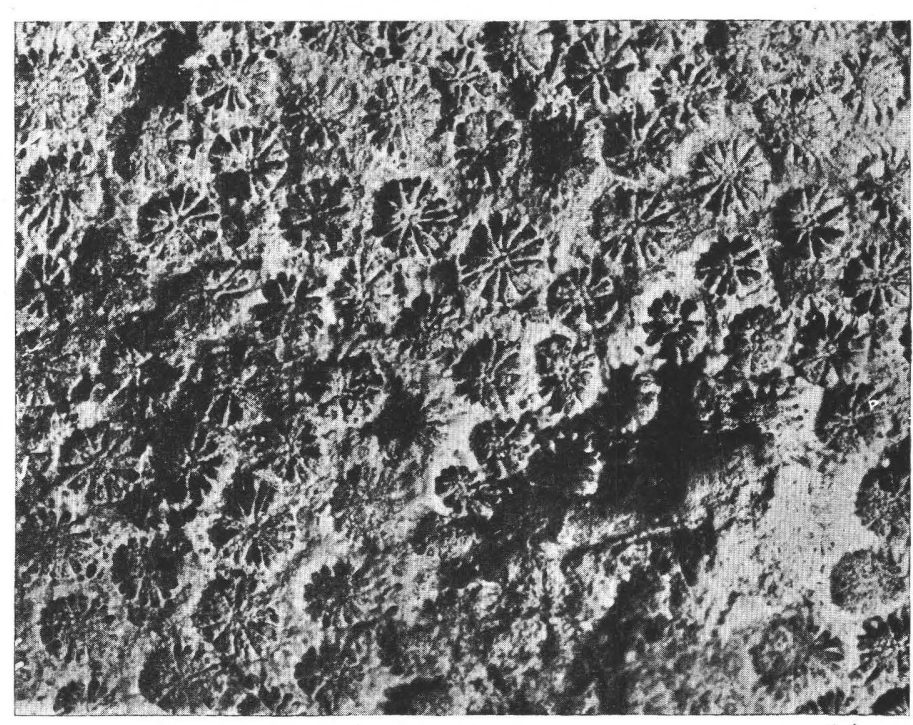

$2^{a}$

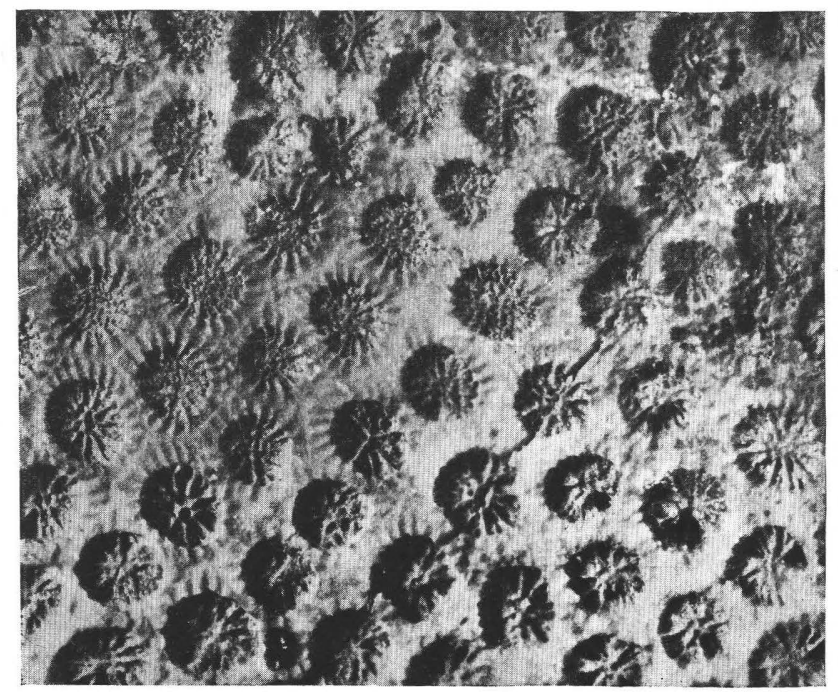

$2 \mathrm{~b}$

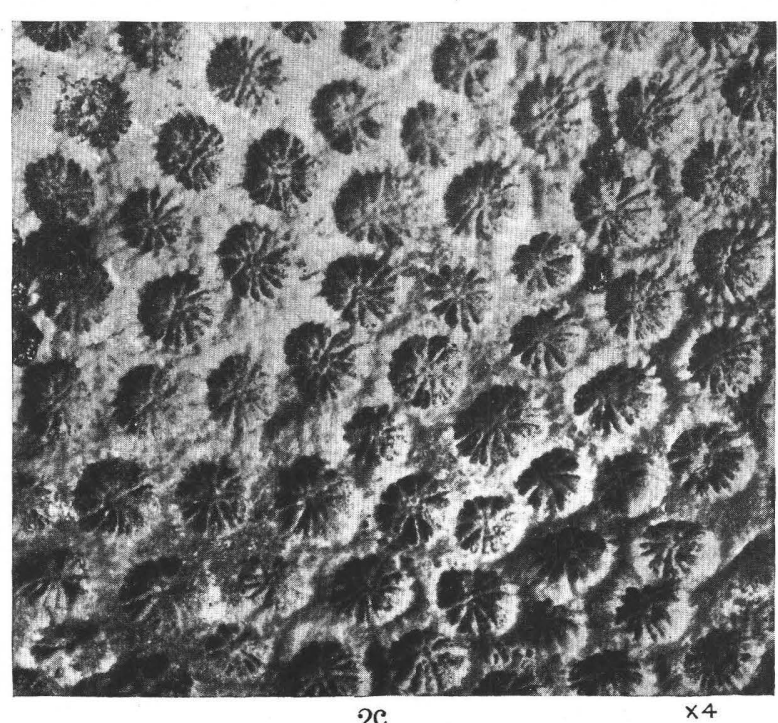

$2 c$

REEF CORALS. 


\section{PLATE XCVII.}

Page.

Figures 1, 1a. Solenastrea fairbanksi var. normalis Vaughan, n. var., from Carrizo Creek, Cal. (See PI. XCVI,

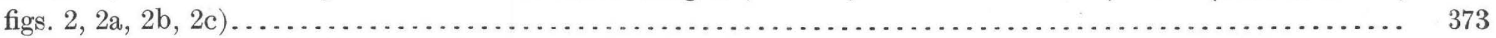

1. Corallum, one-half natural size.

1a. Calices, $\times 4$.

Figures 2, 2a, 2b, 2c. Solenastrea fairbanksi var. minor Vaughan, n. var., from Carrizo Creek, Cal........... 373 2. Corallum, one-half natural size.

$2 \mathrm{a}, 2 \mathrm{~b}, 2 \mathrm{c}$. Calices, each $\times 4$, from three areas. 


\section{PLATE XCVIII。}

Solenastrea hyades (Dana) from the Pliocene Caloosahatchee marl of Florida.......................... 374

Figures 1, 1a. Two views of the same specimen.

1. Corallum, natural size.

1a. Calices, $\times 4$.

Figures 2, 2a. Two views of another specimen.

2. Corallum, natural size.

2a. Calices, $\times 4$.

Figure 3. Corallum of a third specimen, natural size.

382 


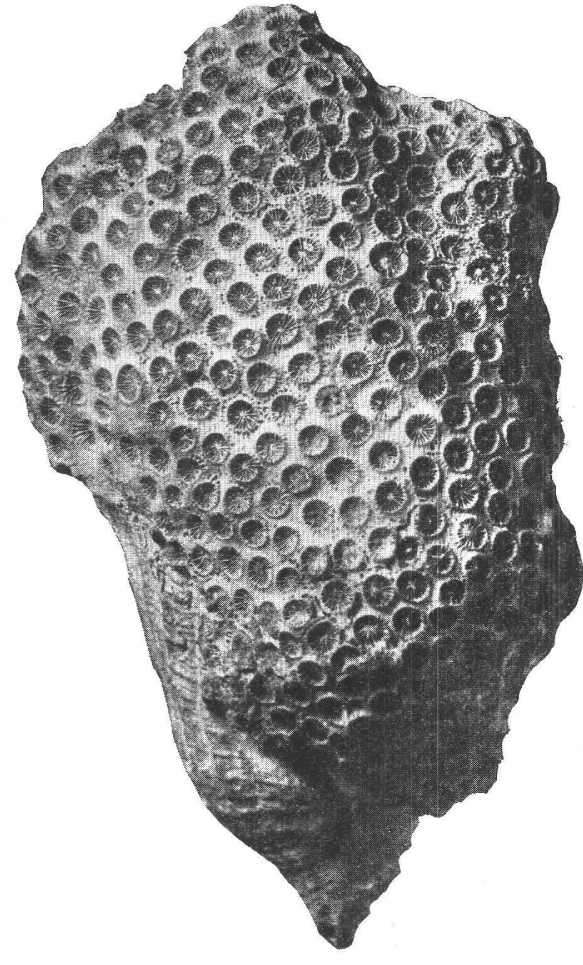

1

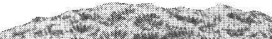

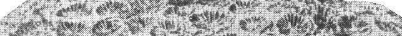

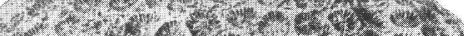

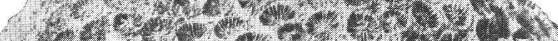

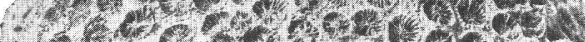

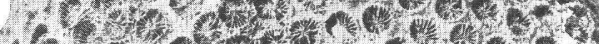

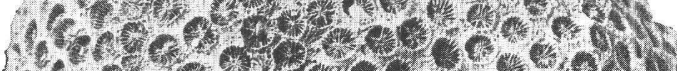

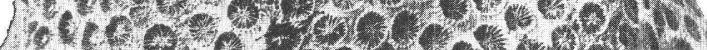

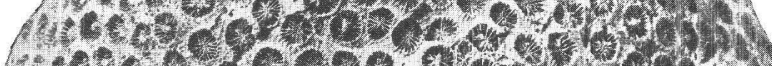

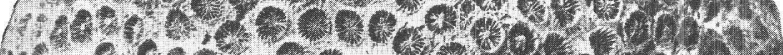

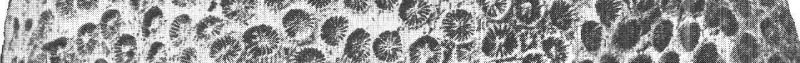

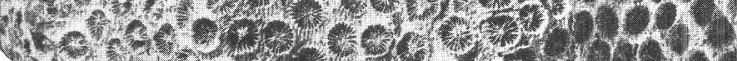

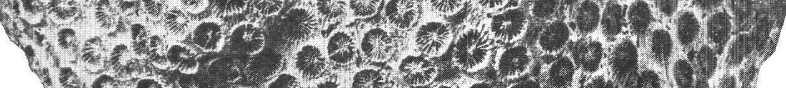

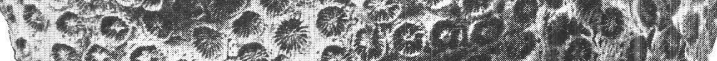

3696romer

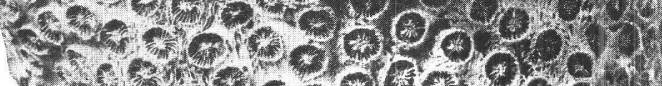

(3),

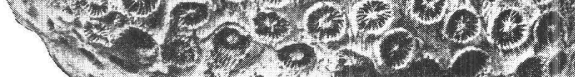

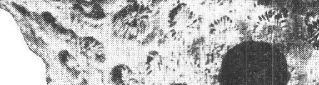

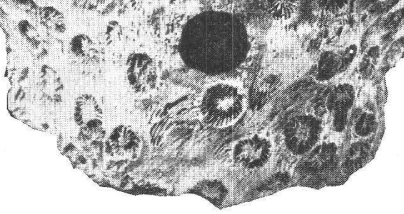

3
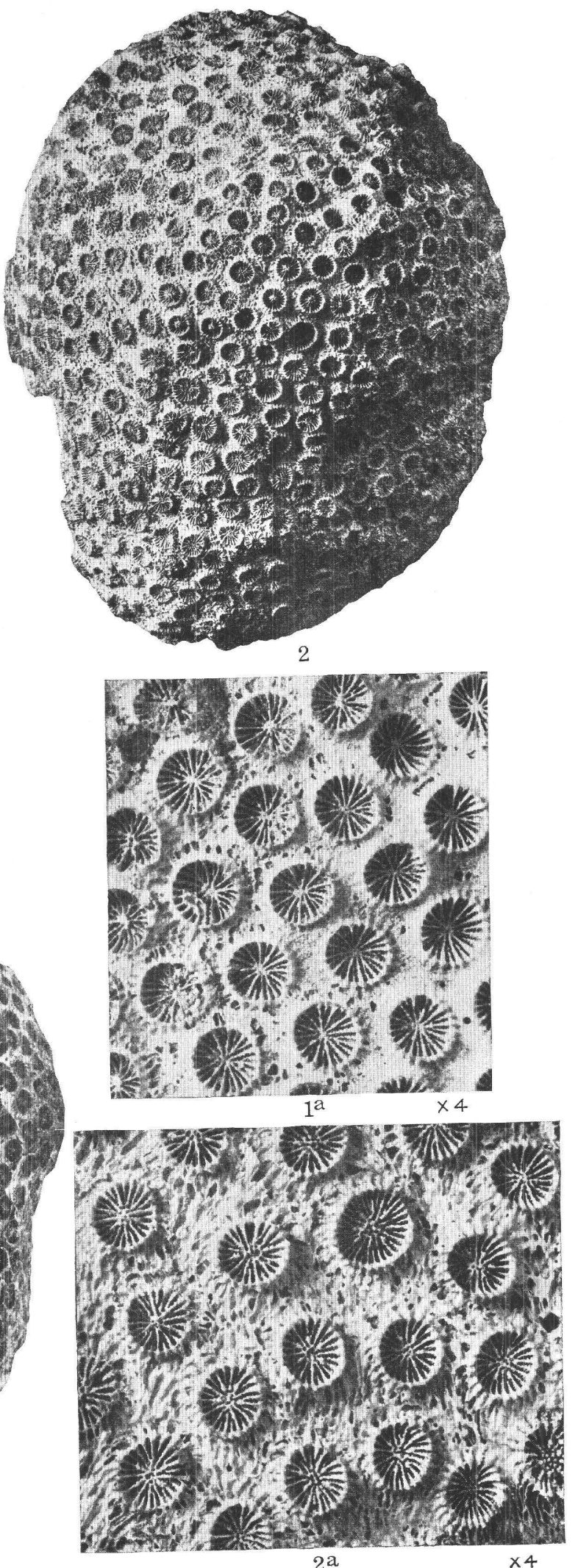

$2^{a}$

REEF CORALS. 


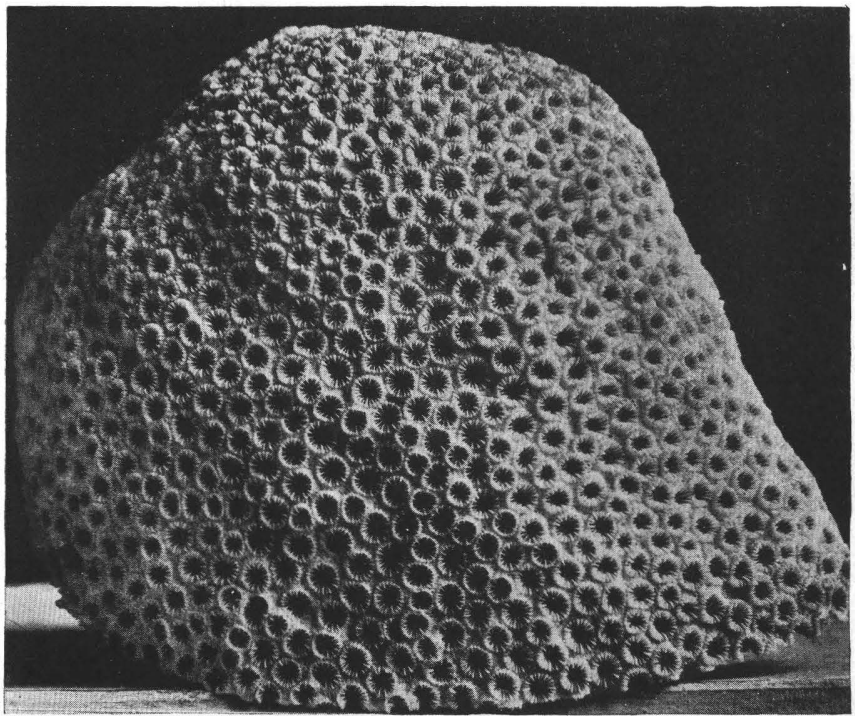

1

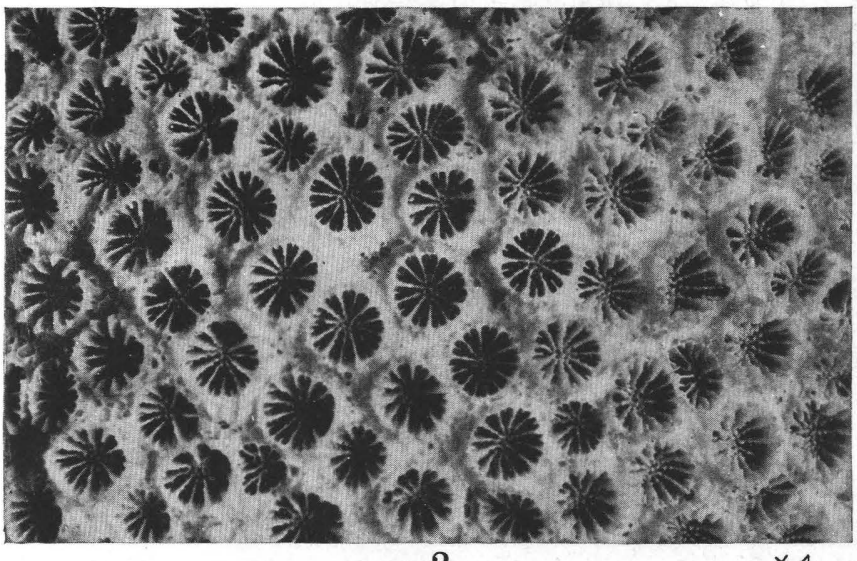

2

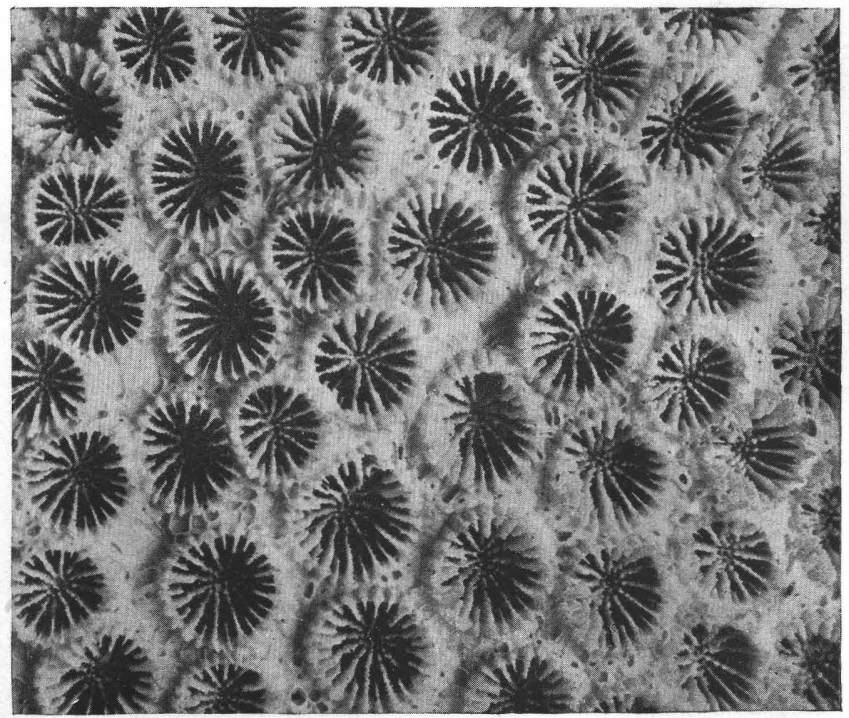

$1^{\mathrm{a}}$

$\times 4$

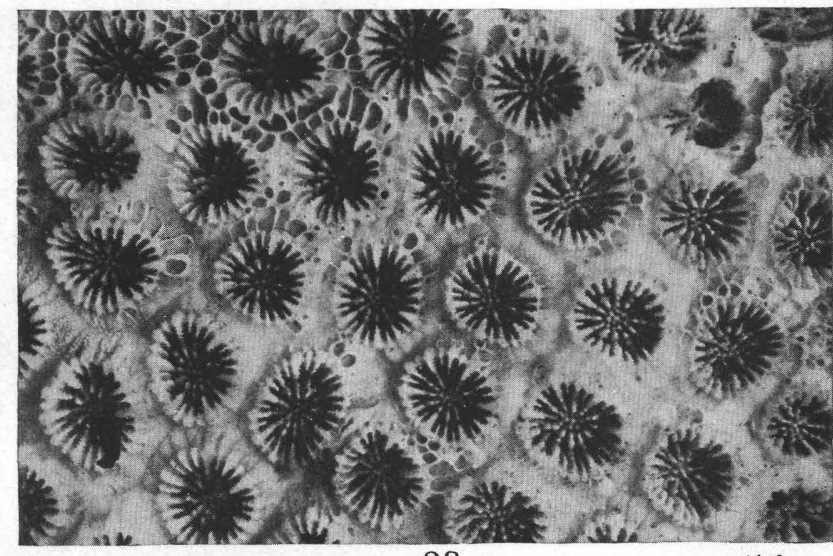

$3^{\mathrm{a}}$

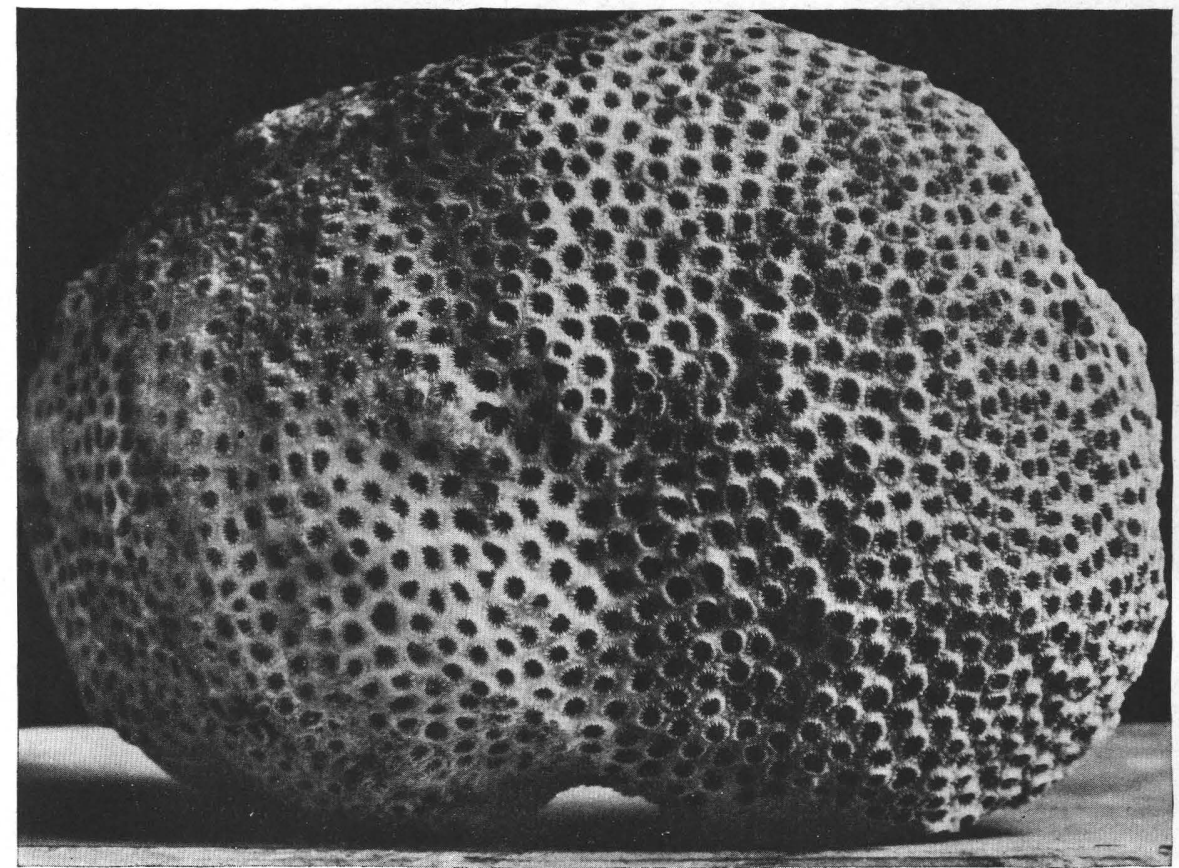

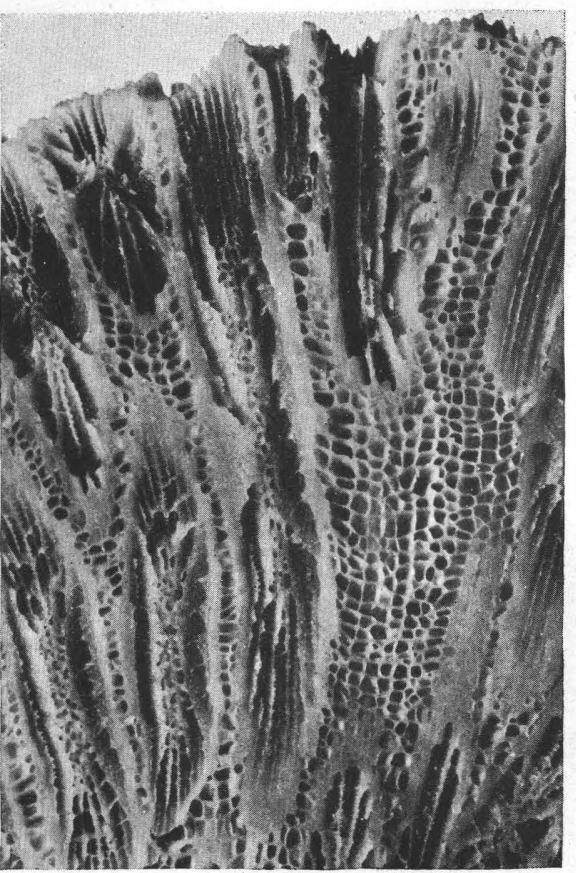

$1^{\mathrm{b}}$ 


\section{PLATE XCIX.}

Solenastrea bournoni Milne Edwards and Haime, a recent species from the West Indies...

Figures 1, 1a, 1b, 2. Cotypes of Solenastrea bournoni in the Muséum d'histoire naturelle, Paris.

1. Corallum, natural size; la, calices, $\times 4$; 1b, longitudinal section, $\times 4$, of the same specimen.

2. Calices of a second specimen, $\times 4$. (This specimen may be the true type.)

Figures 3, 3a. Specimen labeled Cyphastrea oblita Duchassaing and Michelotti, in the Muséum d'histoire naturelle, Paris.

3. Corallum, natural size.

3a. Calices, $\times 4$.

The photographic negatives on which the figures in this plate are based were kindly supplied by Dr. Charles Gravier, of the Muséum d'histoire naturelle, Paris. 


\section{PLATE C.}

Solenastrea bournoni Milne Edwards and Haime.

Figure 1. Calices of a specimen from the Pliocene Caloosahatchee marl of Florida, $\times 4$.

Figures 2, 2a. Two views of the same specimen, from the Caloosahatchee marl.

2. Transverse section of corallites, $\times 4$.

2a. Longitudinal section of corallites, $\times 4$.

Figures 3, 3a, 3b. Three views of a part of Duncan's type of Plesiastrea globosa (presented to the U. S. National Museum by the Geological Society of London), from "silt of the plain, Santo Domingo."

3. Corallum, natural size.

3a. Calices, $\times 4$.

3b. Longitudinal section, $\times 4$.

384 


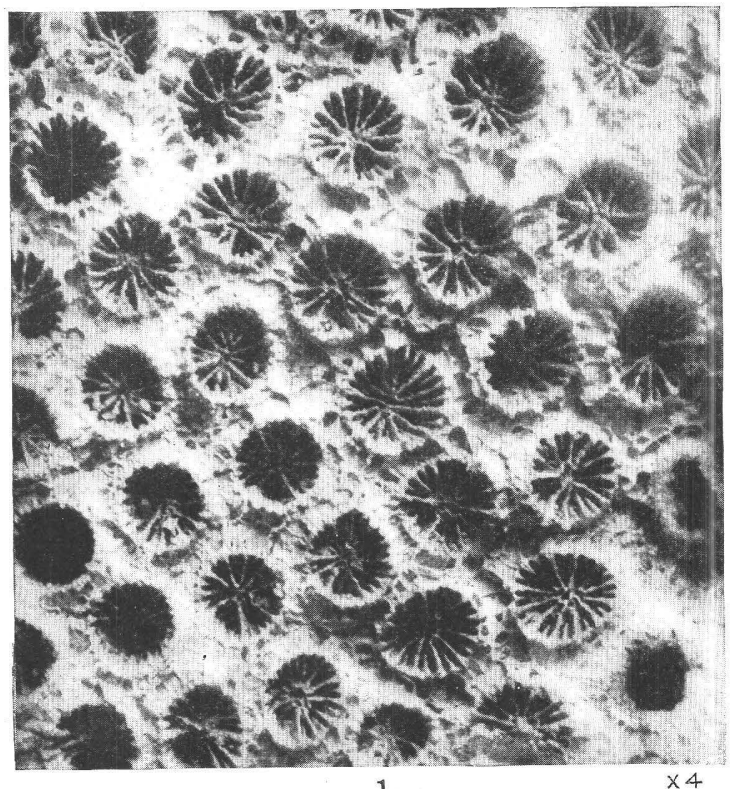

1
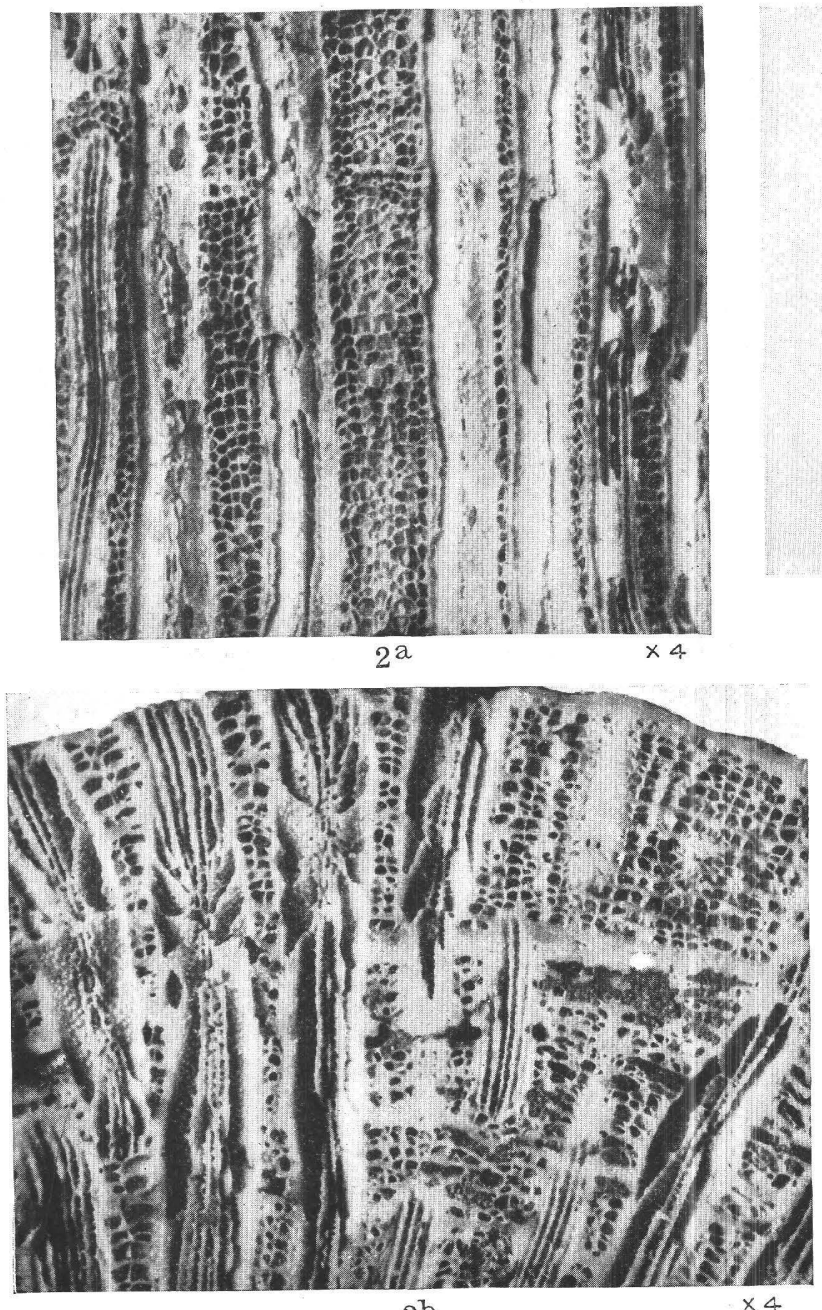
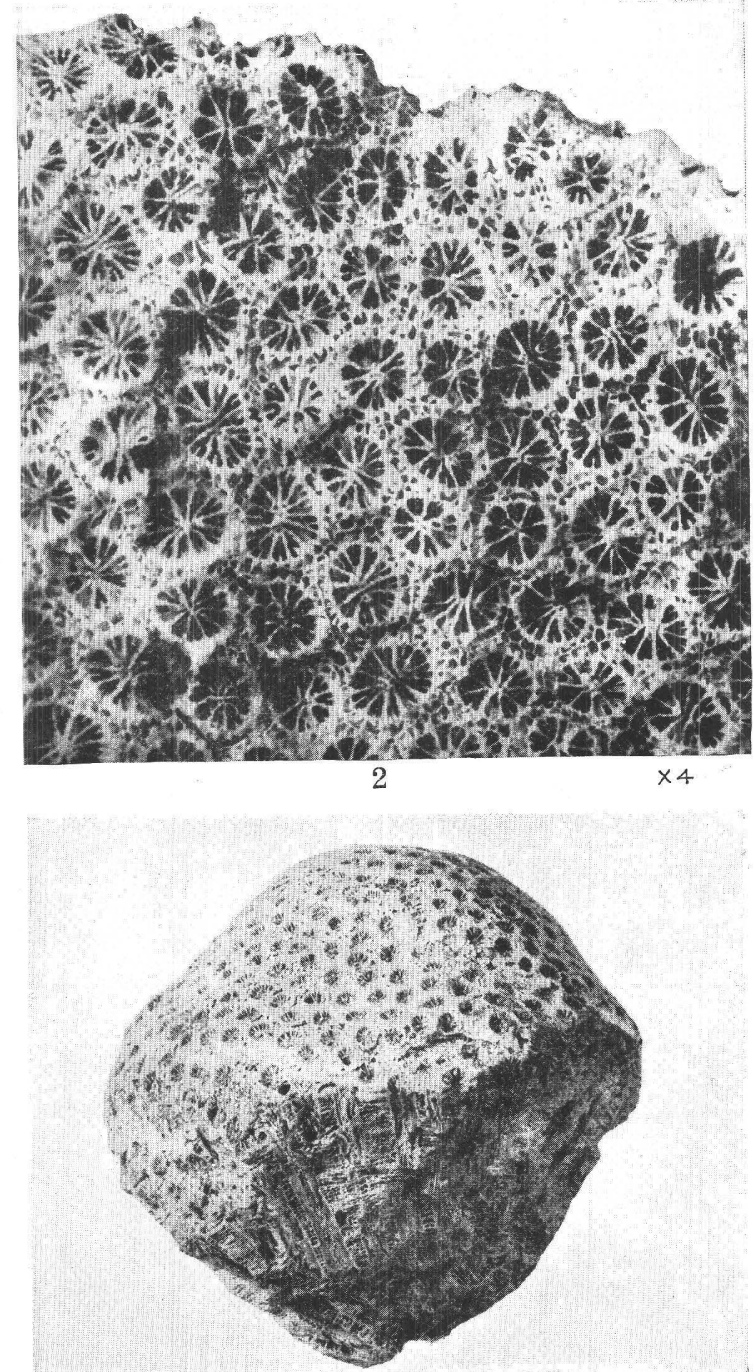

3

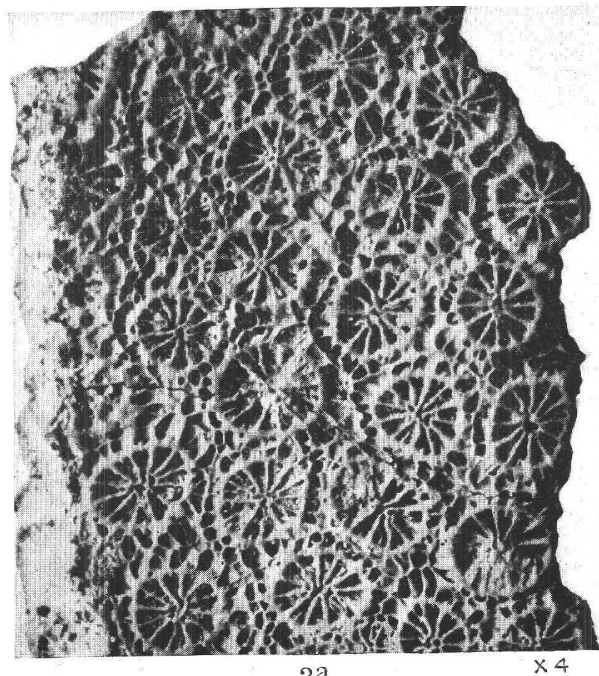

$3^{a}$

REEF CORALS. 

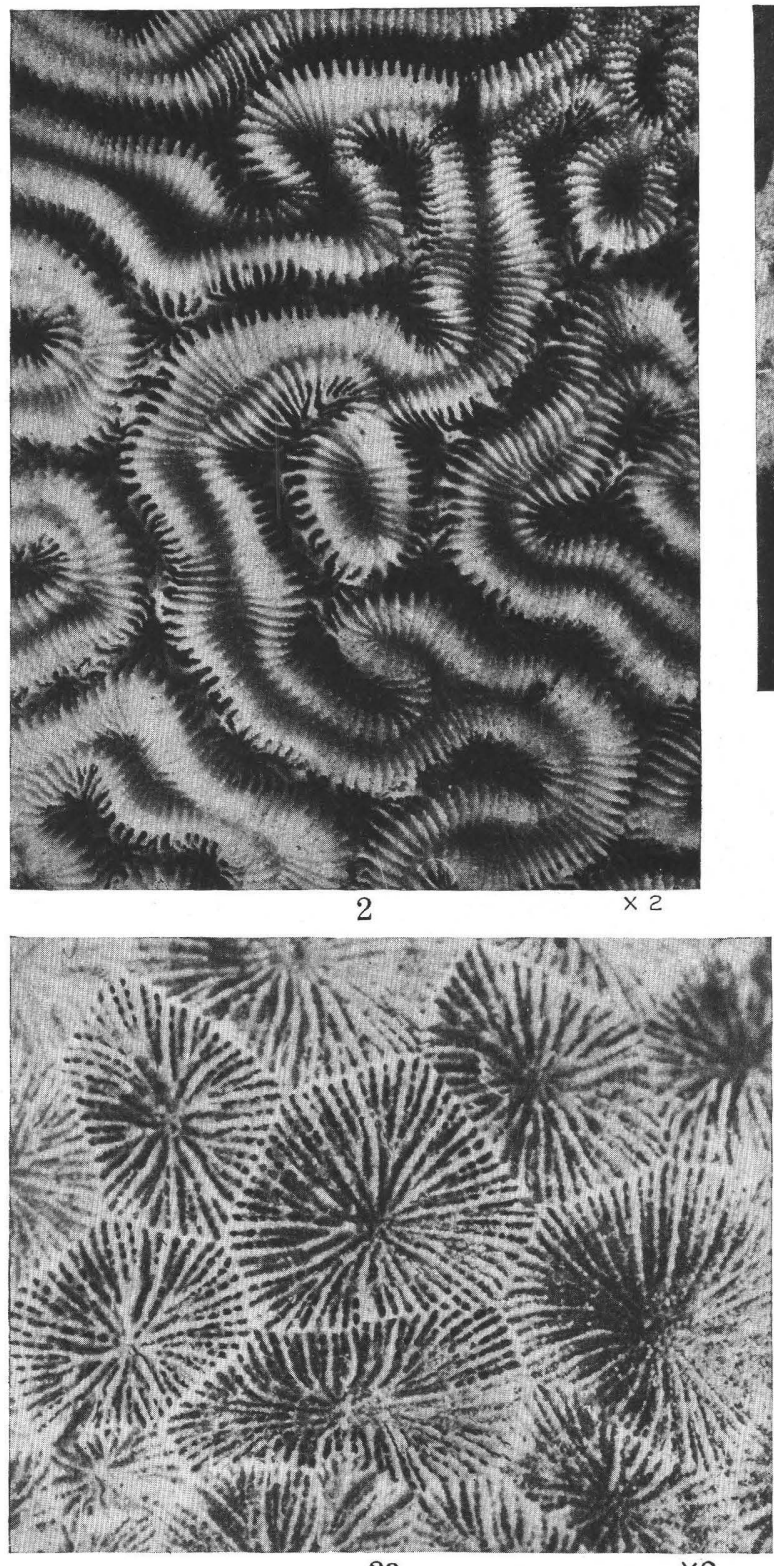

$3 a$

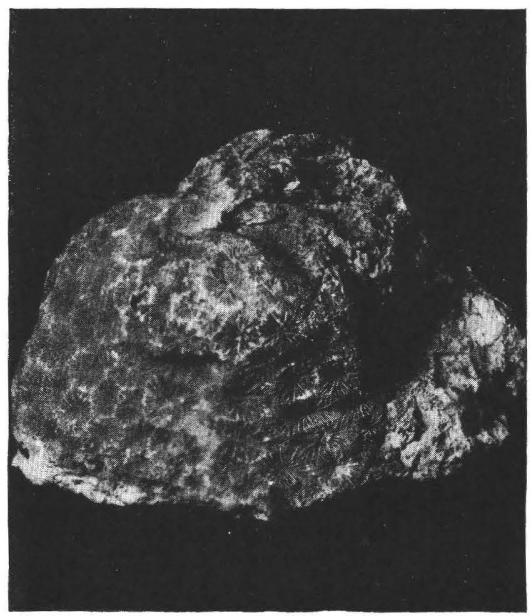

3

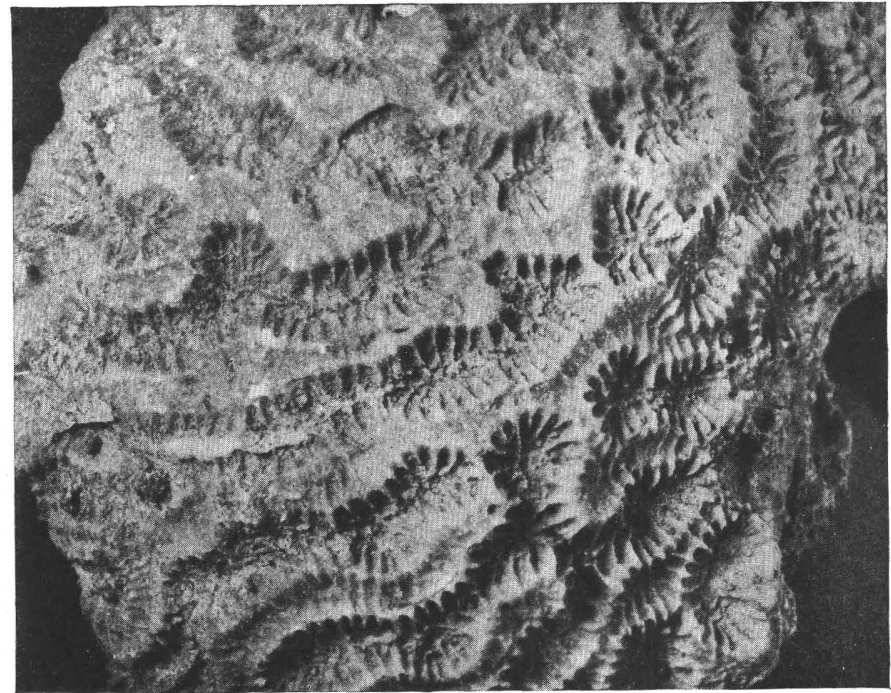

$1 \mathrm{a}$

$\times 2$

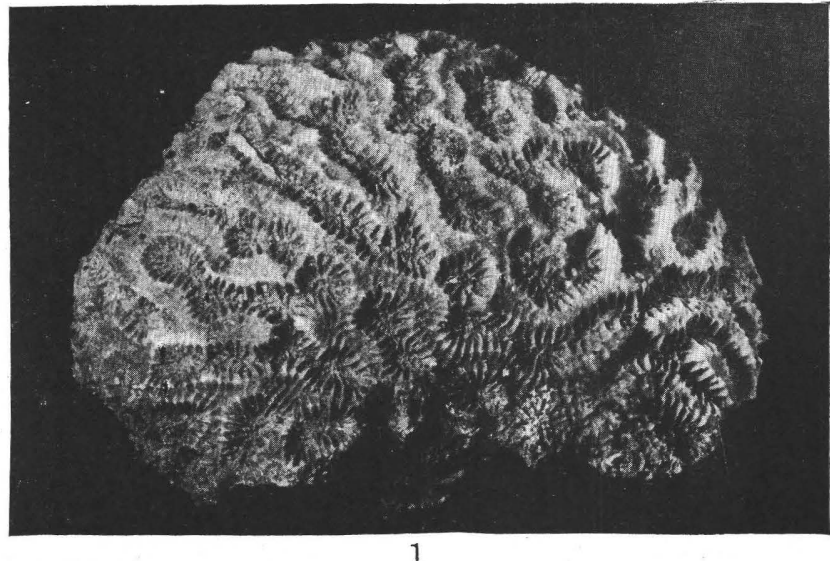

1

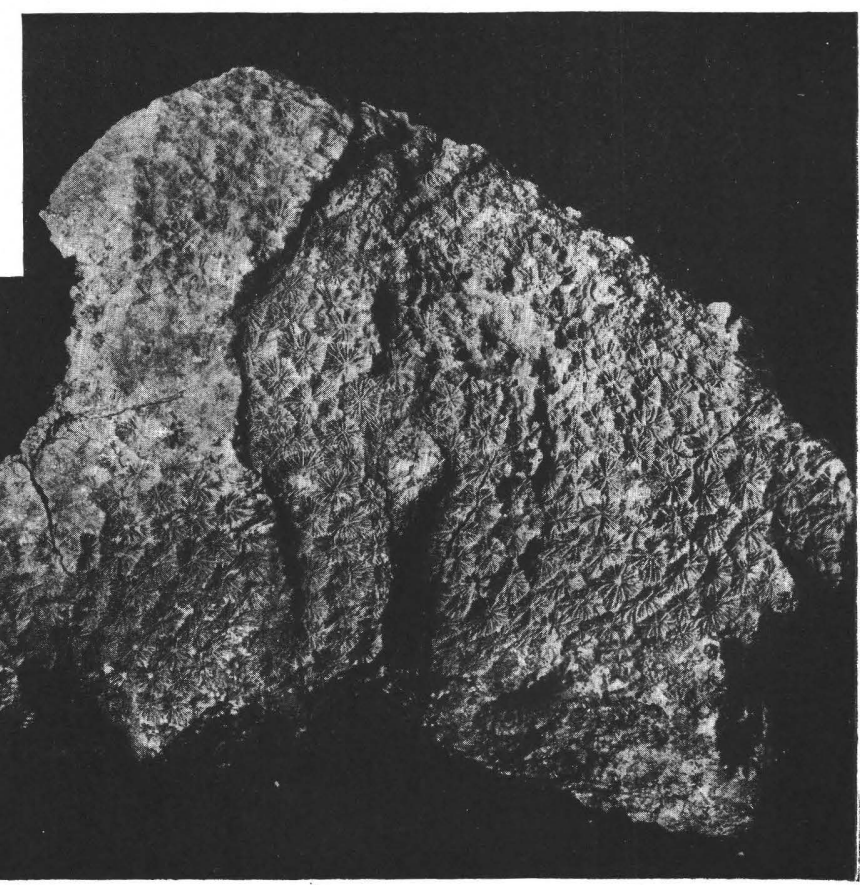

REEF CORALS. 
PLATE CI.

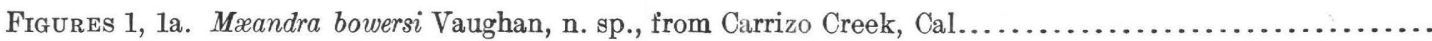

1. Corallum, natural size.

1a. Part of calicular surface, $\times 2$.

Figure 2. Mrandra labyrinthiformis (Linnæus), the type species of the genus, from Cocoanut Point, east side of

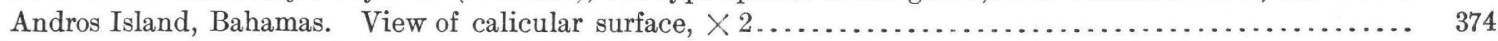

Figures 3, 3a, 4. Siderastrea mendenhalli Vaughan, n. sp., from Carrizo Creek, Cal...................... 374

3, 3a. Two views of the same specimen. 3, Corallum, natural size; 3a, calices, $\times 6$.

4. Calicular surface of another specimen, natural size. 


\section{PLATE CII.}

Figure 1. Siderastrea mendenhalli var. minor Vaughan, n. var., from Carrizo Creek, Cal. Calices, $\times 4 \ldots \ldots \ldots . .375$

Figures 2, 2a, 3, 4. Siderastrea californica Vaughan, n. sp., from Carrizo Creek, Cal.................... 375

2, 2a. Two views of the holotype. 2, Upper surface of the corallum, natural size; $2 \mathrm{a}$, calices, $\times 6$.

3. Calices of a paratype, $\times 6$.

4. Calices of a second paratype, $\times 6$.

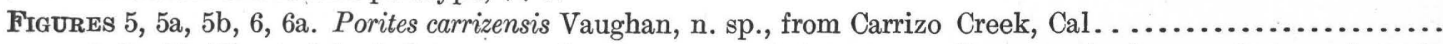

5 , 5a, 5b, Views of the holotype. 5, Corallum, natural size; 5a, a calice retouched on a photograph, $\times 8$; $5 \mathrm{~b}$, the calice represented by $5 \mathrm{a}$ from the same photograph but without retouching.

$6,6 \mathrm{a}$, Calices of a paratype. In figure 6 one calice has been retouched on the photograph; figure $6 \mathrm{a}$ is from a photograph on which none of the calices were retouched. 

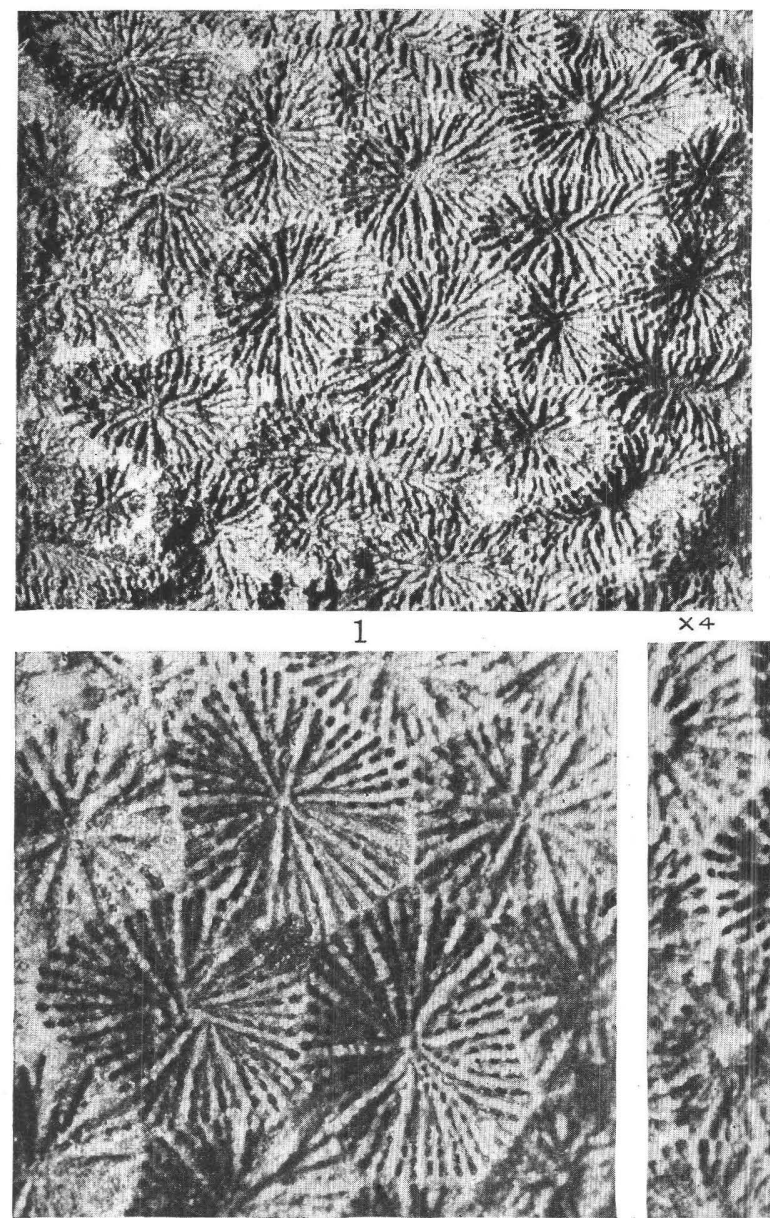

$2^{\mathrm{a}}$
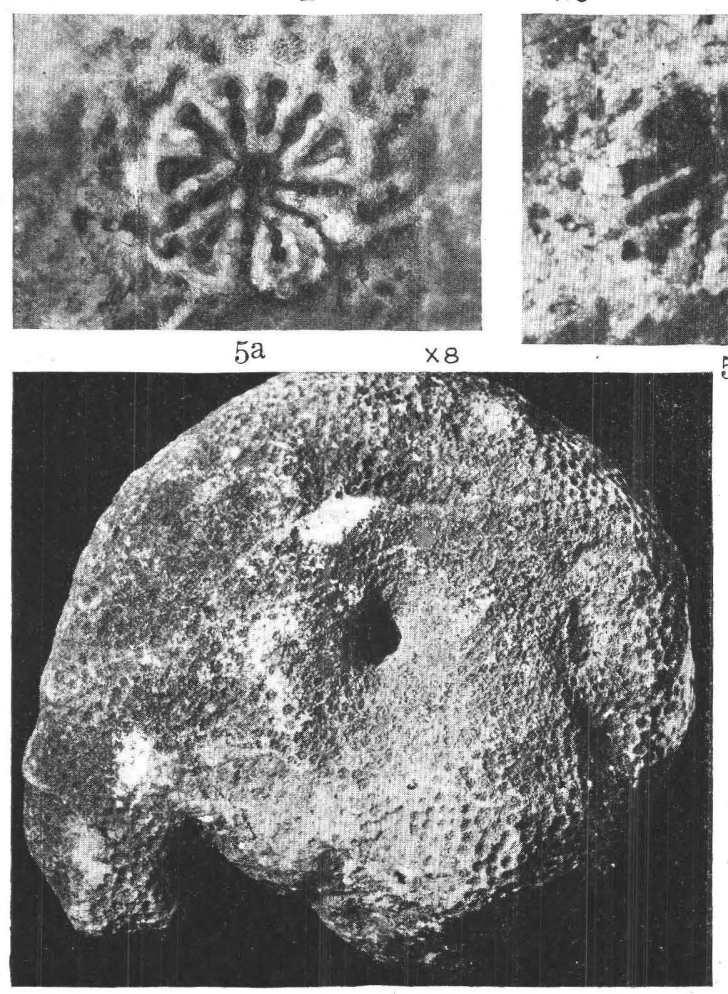

5

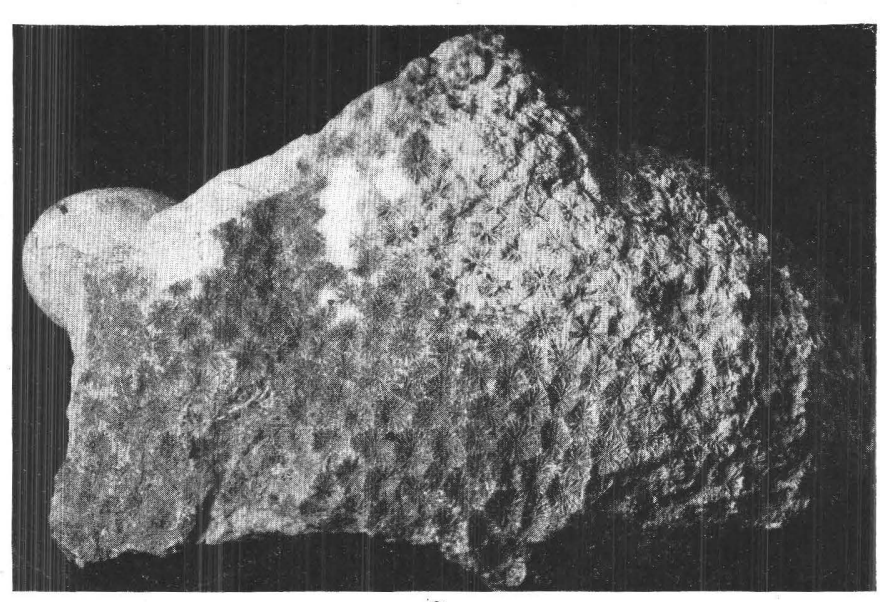

2
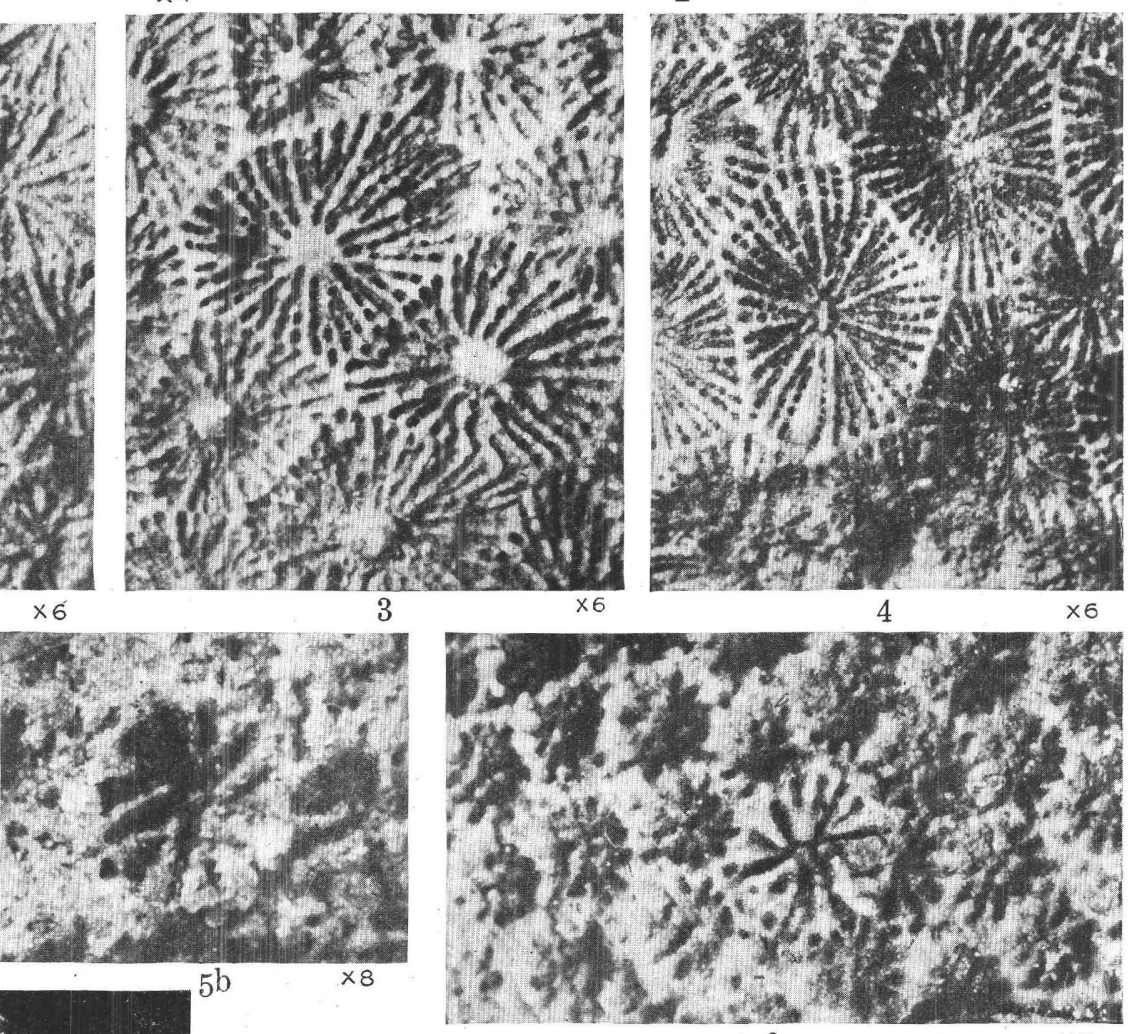

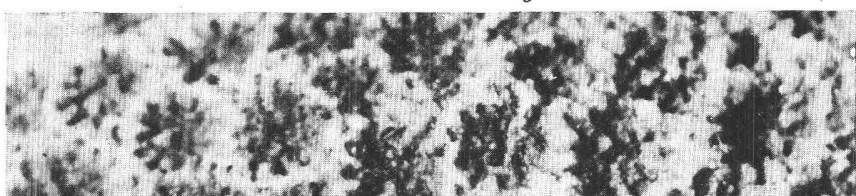

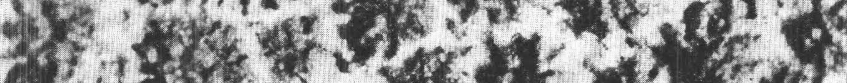

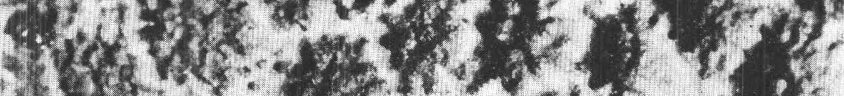

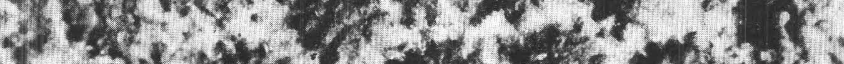

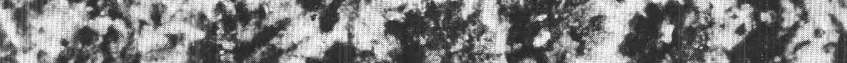

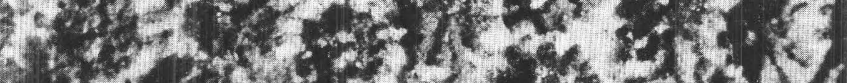

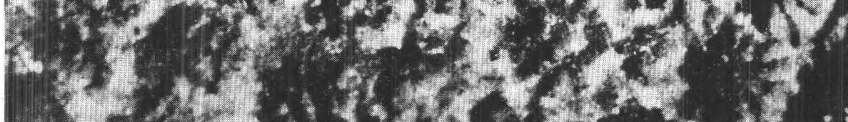
$6 \mathrm{a}$ $\times 8$ 